\title{
Interplay between $n \rightarrow \pi *$ Interactions and Dynamic Covalent Bonds: Quantification and Modulation by Solvent Effects
}

Hao Zheng, ${ }^{\text {a, c }}$ Hebo Ye, ${ }^{\text {a, b }}$ Xiaoxia Yu, a, c and Lei You ${ }^{\text {a, b, * }}$

a. State Key Laboratory of Structural Chemistry, Fujian Institute of Research on the Structure of Matter, Chinese Academy of Sciences, Fuzhou 350002, China.

b. University of Chinese of Academy of Sciences, Beijing 100049, China.

c. College of Chemistry and Material Science, Fujian Normal University, Fuzhou 350007, China. 


\section{Table of Contents}

1. General Methods........................................S3

2. Synthesis and Characterization

(1) Synthesis of $1(\mathrm{X})$ and $1(p-\mathrm{X}) \ldots . . . \ldots \ldots \ldots \ldots . . . . . . .53-S 8$

(2) Synthesis of water soluble compounds.......... S8-S10

(3) NMR spectrum of synthetic compounds......S11-S13

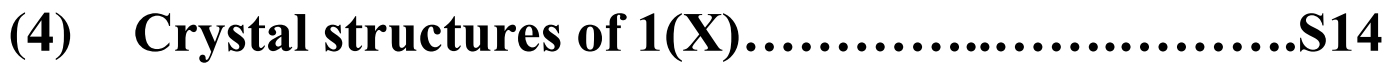

3. Dynamic Covalent Reactions

(1) Imine formation..............................S15-S29

(2) Imine exchange.................................S30-S41

4. Correlation with $n \rightarrow \pi^{*}$ Interaction.................S42-S46

5. Solvent Effect

(1) Solvent effect on thermodynamics..............S47-S51

(2) Solvent effect on kinetics........................S52-S57

(3) Solvent effect on $n \rightarrow \pi^{*}$ interaction .............S57-S58

6. Imine Formation in Aqueous Phase..................S59-S66

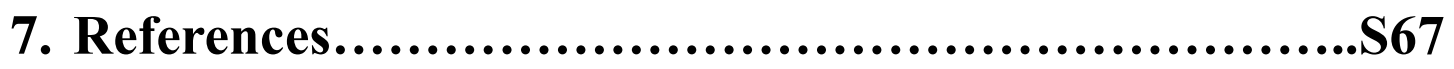




\section{General Methods}

${ }^{1} \mathrm{H}$ NMR and ${ }^{13} \mathrm{C}$ NMR spectra were recorded on a $400 \mathrm{MHz}$ Bruker Biospin Avance III spectrometer or a $400 \mathrm{MHz}$ JEOL JNM-ECZ400S spectrometer. The chemical shifts $(\delta)$ for ${ }^{1} \mathrm{H}$ NMR spectra, given in ppm, are referenced to the residual proton signal of the deuterated solvent. Mass spectra were recorded on a Bruker IMPACT-II spectrometer. Crystallographic data was collected on a Mercury single crystal diffractometer at room temperature. The structures were solved with direct methods by using SHELXS-97 and refined with the full-matrix least-squares technique based on F2. Deuterium solvents were purchased from Aldrich. All other reagents were obtained from commercial sources and were used without further purification, unless indicated otherwise. The experimental details of dynamic covalent reactions, computational studies, and imine formation in water are shown in page $\mathrm{S} 15, \mathrm{~S} 42$, and S59, respectively.

\section{Synthesis and Characterization}

\section{(1) Synthesis of 1(X) and 1(p-X)}

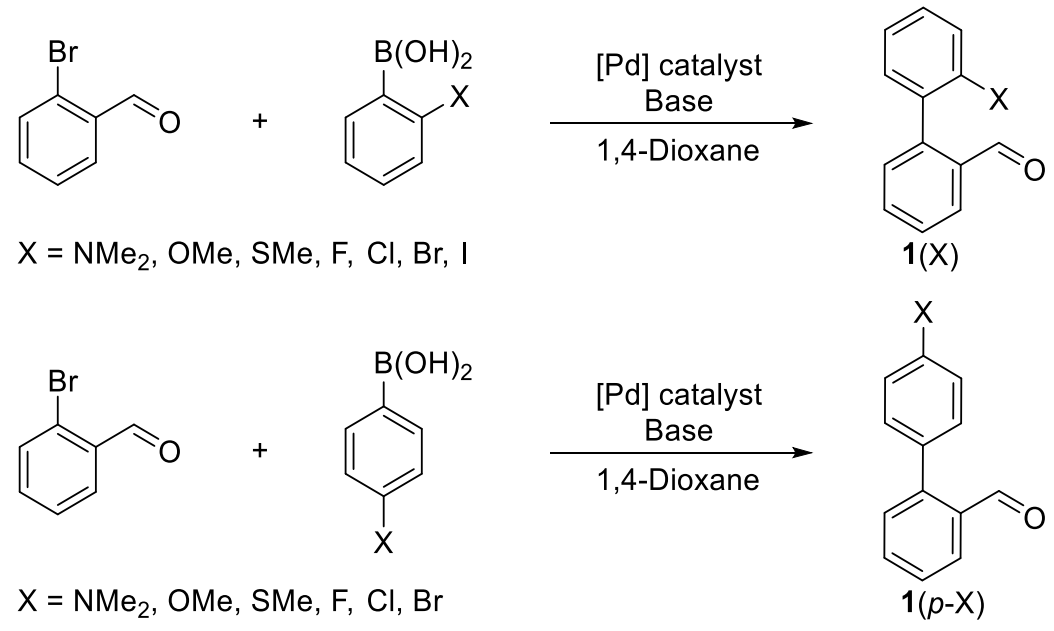

Scheme S1. General synthetic routes of $\mathbf{1}(\mathrm{X})$ and $\mathbf{1}(p-\mathrm{X})$. 
2'-(methylthio)-[1,1'-biphenyl]-2-carbaldehyde: To a mixture of 2-bromobenzaldehyde (1.0 mmol, $185 \mathrm{mg})$, (2-(methylthio)phenyl)boronic acid (1.2 mmol, $202 \mathrm{mg})$, potassium carbonate $(2.0 \mathrm{mmol}, 276 \mathrm{mg})$, and tetrakis(triphenylphosphine)palladium (0.005 mmol, $58 \mathrm{mg}$ ), was added 1,4-dioxane $(10 \mathrm{~mL})$ under $\mathrm{N}_{2}$ atmosphere. The reaction was stirred at $80{ }^{\circ} \mathrm{C}$ for $12 \mathrm{~h}$. After the reaction was cooled to room temperature, $\mathrm{H}_{2} \mathrm{O}(25 \mathrm{ml})$ was added, and the mixture was extracted with ethyl acetate $(\mathrm{EA} ; 25 \mathrm{ml} \times 3)$. The combined organic layer was washed with saturated aqueous $\mathrm{NH}_{4} \mathrm{Cl}(50 \mathrm{ml} \times 3)$ and dried over anhydrous $\mathrm{Na}_{2} \mathrm{SO}_{4}$. After removal of solvent under vacuum and further purification performed on the column chromatography (silica gel, petroleum ether $(\mathrm{PE}) / \mathrm{EA}=40: 1$ to $20: 1$ ), the title compound was obtained as a white solid $(216 \mathrm{mg}, 95 \%) .{ }^{1} \mathrm{H}$ NMR (DMSO-d 6 ): $\delta$ $9.61(\mathrm{~s}, 1 \mathrm{H}), 7.91(\mathrm{dd}, J=7.7,1.1 \mathrm{~Hz}, 1 \mathrm{H}), 7.77(\mathrm{td}, J=7.5,1.3 \mathrm{~Hz}, 1 \mathrm{H}), 7.61(\mathrm{t}, J=$ $7.6 \mathrm{~Hz}, 1 \mathrm{H}), 7.48$ (t, $J=6.6 \mathrm{~Hz}, 1 \mathrm{H}), 7.35(\mathrm{t}, J=8.2 \mathrm{~Hz}, 2 \mathrm{H}), 7.32-7.23(\mathrm{~m}, 2 \mathrm{H}), 2.36$ (s, 3H). ${ }^{13} \mathrm{C} \mathrm{NMR}\left(\mathrm{CDCl}_{3}\right): \delta 191.9,143.8,138.3,136.3,133.9,133.9,131.0,130.4$, 129.0, 128.5, 127.0, 124.7, 124.6, 15.5. ESI-HRMS: $\mathrm{m} / \mathrm{z}$ calcd for $\mathrm{C}_{14} \mathrm{H}_{12} \mathrm{OSNa}[\mathrm{M}+$ $\mathrm{Na}^{+}$]: 251.0501; found: 251.0501 .<smiles>COc1ccccc1-c1ccccc1C=O</smiles>

2'-methoxy-[1,1'-biphenyl]-2-carbaldehyde: The reported procedure ${ }^{\mathrm{S} 1}$ was used to afford the title compound as a white crystal (yield: 90\%). ${ }^{1} \mathrm{H}$ NMR $\left(\mathrm{CDCl}_{3}\right): \delta{ }^{1} \mathrm{H} \mathrm{NMR}\left(\mathrm{CDCl}_{3}\right) \delta 9.81(\mathrm{~s}, 1 \mathrm{H}), 8.02(\mathrm{dd}, J=7.8,1.3 \mathrm{~Hz}, 1 \mathrm{H}), 7.67(\mathrm{td}, J$ $=7.5,1.4 \mathrm{~Hz}, 1 \mathrm{H}), 7.51(\mathrm{t}, J=7.6 \mathrm{~Hz}, 1 \mathrm{H}), 7.48-7.42(\mathrm{~m}, 1 \mathrm{H}), 7.39(\mathrm{~d}, J=7.7 \mathrm{~Hz}$, 1H), $7.32(\mathrm{dd}, J=7.5,1.7 \mathrm{~Hz}, 1 \mathrm{H}), 7.11(\mathrm{t}, J=7.0 \mathrm{~Hz}, 1 \mathrm{H}), 7.01(\mathrm{~d}, J=8.1 \mathrm{~Hz}, 1 \mathrm{H})$, $3.77(\mathrm{~s}, 3 \mathrm{H})$. 
2'-(dimethylamino)-[1,1'-biphenyl]-2-carbaldehyde: The reported procedure $^{\mathrm{S} 2}$ was used to afford the title compound as a yellow solid (yield: $96 \%$ ). ${ }^{1} \mathrm{H}$ NMR $\left(\mathrm{CD}_{3} \mathrm{CN}\right): 9.54(\mathrm{~s}, 1 \mathrm{H}), 7.88(\mathrm{dd}, J=7.7,1.2 \mathrm{~Hz}, 1 \mathrm{H}), 7.74(\mathrm{td}, J=7.5,1.4 \mathrm{~Hz}$, 1H), $7.52(\mathrm{t}, J=7.5 \mathrm{~Hz}, 1 \mathrm{H}), 7.48-7.45(\mathrm{~m}, 1 \mathrm{H}), 7.42(\mathrm{td}, J=7.9,1.7 \mathrm{~Hz}, 1 \mathrm{H}), 7.38$ (dd, $J=7.5,1.6 \mathrm{~Hz}, 1 \mathrm{H}), 7.23-7.14(\mathrm{~m}, 2 \mathrm{H}), 2.37$ (s, 6H).<smiles>O=Cc1ccccc1-c1ccccc1F</smiles>

2'-fluoro-[1,1'-biphenyl]-2-carbaldehyde: The reported procedure ${ }^{\mathrm{S} 3}$ was used to afford the title compound as a colorless oil (yield: 60\%). ${ }^{1} \mathrm{H}$ NMR (DMSO-d $\left.)_{6}\right): \delta 9.83(\mathrm{~s}, 1 \mathrm{H}), 7.96(\mathrm{~d}, J=7.3 \mathrm{~Hz}, 1 \mathrm{H}), 7.80(\mathrm{t}, J=7.5 \mathrm{~Hz}, 1 \mathrm{H}), 7.65$ (t, $J=7.5 \mathrm{~Hz}, 1 \mathrm{H}), 7.56-7.46(\mathrm{~m}, 3 \mathrm{H}), 7.38-7.32(\mathrm{~m}, 2 \mathrm{H})$.<smiles>O=Cc1ccccc1-c1ccccc1Cl</smiles>

2'-chloro-[1,1'-biphenyl]-2-carbaldehyde: The reported procedure ${ }^{\mathrm{S} 3}$ was used to afford the title compound as a white solid (yield: $55 \%) .{ }^{1} \mathrm{H} \mathrm{NMR}\left(\mathrm{CDCl}_{3}\right)$ : $\delta 9.83(\mathrm{~s}, 1 \mathrm{H}), 8.07(\mathrm{dd}, J=7.8,1.1 \mathrm{~Hz}, 1 \mathrm{H}), 7.70(\mathrm{td}, J=7.5,1.4 \mathrm{~Hz}, 1 \mathrm{H}), 7.58(\mathrm{t}, J$ $=7.6 \mathrm{~Hz}, 1 \mathrm{H}), 7.55-7.51(\mathrm{~m}, 1 \mathrm{H}), 7.45-7.39(\mathrm{~m}, 2 \mathrm{H}), 7.37(\mathrm{~m}, 2 \mathrm{H})$.<smiles>O=Cc1ccccc1-c1ccccc1Br</smiles>

2'-bromo-[1,1'-biphenyl]-2-carbaldehyde: The reported procedure ${ }^{\mathrm{S} 3}$ 
was used to afford the title compound as a yellow solid (yield: 63\%). ${ }^{1} \mathrm{H}$ NMR (DMSO-d $\left.)_{6}\right): \delta .71(\mathrm{~s}, 1 \mathrm{H}), 7.95(\mathrm{dd}, J=7.7,1.1 \mathrm{~Hz}, 1 \mathrm{H}), 7.81-7.74(\mathrm{~m}, 2 \mathrm{H}), 7.65(\mathrm{t}$, $J=7.5 \mathrm{~Hz}, 1 \mathrm{H}), 7.52(\mathrm{td}, J=7.5,1.1 \mathrm{~Hz}, 1 \mathrm{H}), 7.47-7.35(\mathrm{~m}, 3 \mathrm{H})$.<smiles>O=Cc1ccccc1-c1ccccc1I</smiles>

2'-iodo-[1,1'-biphenyl]-2-carbaldehyde: The reported procedure ${ }^{\mathrm{S} 4}$ was used to afford the title compound as a drab solid (yield: 57\%). ${ }^{1} \mathrm{H}$ NMR (DMSO-d $)$ ): $\delta 9.68(\mathrm{~s}, 1 \mathrm{H}), 8.00(\mathrm{dd}, J=7.9,0.9 \mathrm{~Hz}, 1 \mathrm{H}), 7.95(\mathrm{dd}, J=7.8,1.1 \mathrm{~Hz}, 1 \mathrm{H}), 7.78(\mathrm{td}$, $J=7.5,1.4 \mathrm{~Hz}, 1 \mathrm{H}), 7.64(\mathrm{t}, J=7.6 \mathrm{~Hz}, 1 \mathrm{H}), 7.53(\mathrm{td}, J=7.5,1.1 \mathrm{~Hz}, 1 \mathrm{H}), 7.41(\mathrm{dd}$, $J=7.6,1.6 \mathrm{~Hz}, 1 \mathrm{H}), 7.31(\mathrm{~d}, J=7.6 \mathrm{~Hz}, 1 \mathrm{H}), 7.21(\mathrm{td}, J=7.7,1.7 \mathrm{~Hz}, 1 \mathrm{H})$.<smiles>CN(C)c1ccc(-c2ccccc2C=O)cc1</smiles>

4'-(dimethylamino)-[1,1'-biphenyl]-2-carbaldehyde: The reported procedure ${ }^{\mathrm{S} 5}$ was used to afford the title compound as a yellow solid (yield: $97 \%$ ). ${ }^{1} \mathrm{H}$ NMR $\left(\mathrm{CDCl}_{3}\right): \delta 10.03(\mathrm{~s}, 1 \mathrm{H}), 7.99(\mathrm{dd}, J=7.8,1.2 \mathrm{~Hz}, 1 \mathrm{H}), 7.60(\mathrm{td}, J=7.7,1.5$ $\mathrm{Hz}, 1 \mathrm{H}), 7.45$ (d, $J=8.5 \mathrm{~Hz}, 1 \mathrm{H}), 7.41$ (t, $J=7.5 \mathrm{~Hz}, 1 \mathrm{H}), 7.27(\mathrm{~d}, J=8.8 \mathrm{~Hz}, 2 \mathrm{H})$, $6.81(\mathrm{~d}, J=8.8 \mathrm{~Hz}, 2 \mathrm{H}), 3.03(\mathrm{~s}, 6 \mathrm{H})$.<smiles>COc1ccc(-c2ccccc2C=O)cc1</smiles>

4'-methoxy-[1,1'-biphenyl]-2-carbaldehyde: The reported procedure ${ }^{\mathrm{S} 5}$ was used to afford the title compound as a white solid (yield: $95 \%) .{ }^{1} \mathrm{H}$ NMR $\left(\mathrm{CDCl}_{3}\right)$ : $\delta 10.02(\mathrm{~s}, 1 \mathrm{H}), 8.05(\mathrm{dd}, J=7.8,1.1 \mathrm{~Hz}, 1 \mathrm{H}), 7.66(\mathrm{td}, J=7.5,1.5 \mathrm{~Hz}, 1 \mathrm{H}), 7.52(\mathrm{t}, J$ 
$=7.6 \mathrm{~Hz}, 1 \mathrm{H}), 7.48(\mathrm{~d}, J=7.7 \mathrm{~Hz}, 1 \mathrm{H}), 7.43-7.37(\mathrm{t}, J=7.5 \mathrm{~Hz}, 1 \mathrm{H}), 7.04-6.93(\mathrm{~m}$, $3 \mathrm{H}), 3.88$ (s, 3H).<smiles>COC(=O)c1ccccc1-c1ccc(C)cc1</smiles>

4'-(methylthio)-[1,1'-biphenyl]-2-carbaldehyde: The reported procedure $^{\mathrm{S} 6}$ was used to afford the title compound as a white solid (yield: $96 \%$ ). ${ }^{1} \mathrm{H}$ NMR $\left(\mathrm{CDCl}_{3}\right) \delta 9.99(\mathrm{~s}, 1 \mathrm{H}), 8.02(\mathrm{~d}, J=7.8 \mathrm{~Hz}, 1 \mathrm{H}), 7.64(\mathrm{t}, J=7.5 \mathrm{~Hz}, 1 \mathrm{H}), 7.49$ (t, $J=7.4 \mathrm{~Hz}, 1 \mathrm{H}), 7.43(\mathrm{~d}, J=7.7 \mathrm{~Hz}, 1 \mathrm{H}), 7.33$ (q, $J=8.3 \mathrm{~Hz}, 4 \mathrm{H}), 2.55(\mathrm{~s}, 3 \mathrm{H})$.<smiles>O=Cc1ccccc1-c1ccc(F)cc1</smiles>

4'-fluoro-[1,1'-biphenyl]-2-carbaldehyde: The reported procedure ${ }^{\mathrm{S} 3}$ was used to afford the title compound as a white solid (yield: $58 \%) .{ }^{1} \mathrm{H} \mathrm{NMR}\left(\mathrm{CDCl}_{3}\right) \delta$ $9.97(\mathrm{~s}, 1 \mathrm{H}), 8.05-8.00(\mathrm{~m}, 1 \mathrm{H}), 7.64(\mathrm{td}, J=7.5,1.4 \mathrm{~Hz}, 1 \mathrm{H}), 7.51$ (t, $J=7.6 \mathrm{~Hz}$, 1H), $7.42(\mathrm{~d}, J=7.7 \mathrm{~Hz}, 1 \mathrm{H}), 7.35(\mathrm{~m}, 2 \mathrm{H}), 7.17(\mathrm{t}, J=8.6 \mathrm{~Hz}, 2 \mathrm{H})$.<smiles>O=Cc1ccccc1-c1ccc(Cl)cc1</smiles>

4'-chloro-[1,1'-biphenyl]-2-carbaldehyde: The reported procedure ${ }^{\mathrm{S} 3}$ was used to afford the title compound as a white solid (yield: $70 \%) .{ }^{1} \mathrm{H}$ NMR $\left(\mathrm{CDCl}_{3}\right)$ $\delta 9.97(\mathrm{~s}, 1 \mathrm{H}), 8.03(\mathrm{dd}, J=7.8,1.3 \mathrm{~Hz}, 1 \mathrm{H}), 7.65(\mathrm{td}, J=7.5,1.4 \mathrm{~Hz}, 1 \mathrm{H}), 7.52$ (t, $J$ $=7.6 \mathrm{~Hz}, 1 \mathrm{H}), 7.46(\mathrm{~d}, J=8.4 \mathrm{~Hz}, 2 \mathrm{H}), 7.41(\mathrm{dd}, J=7.7,0.9 \mathrm{~Hz}, 1 \mathrm{H}), 7.32(\mathrm{~d}, J=8.4$ $\mathrm{Hz}, 2 \mathrm{H})$. 
<smiles>O=Cc1ccccc1-c1ccc(Br)cc1</smiles>

4'-bromo-[1,1'-biphenyl]-2-carbaldehyde: The reported procedure ${ }^{\mathrm{S} 3}$ was used to afford the title compound as a yellow solid (yield: 66\%). ${ }^{1} \mathrm{H}$ NMR $\left(\mathrm{CDCl}_{3}\right) \delta 9.97(\mathrm{~s}, 1 \mathrm{H}), 8.03(\mathrm{dd}, J=7.8,1.1 \mathrm{~Hz}, 1 \mathrm{H}), 7.68-7.59(\mathrm{~m}, 3 \mathrm{H}), 7.52$ (t, $J$ $=7.6 \mathrm{~Hz}, 1 \mathrm{H}), 7.41(\mathrm{~d}, J=7.7 \mathrm{~Hz}, 1 \mathrm{H}), 7.27-7.25(\mathrm{~m}, 2 \mathrm{H})$.

\section{(2) Synthesis of water soluble compounds}<smiles>O=Cc1cc(O)ccc1Br</smiles>

$\mathrm{X}=\mathrm{H}, \mathrm{OMe}$<smiles>[X]c1ccccc1Br</smiles>

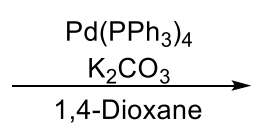<smiles>O=Cc1ccc(O)cc1</smiles>

$$
\begin{aligned}
& \text { 1. } \mathrm{BrCH}_{2} \mathrm{CH}_{2} \mathrm{Br} \\
& \mathrm{K}_{2} \mathrm{CO}_{3}
\end{aligned}
$$

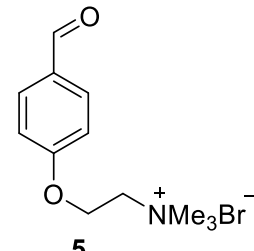<smiles>[X]c1ccccc1-c1ccc(O)cc1C=O</smiles>

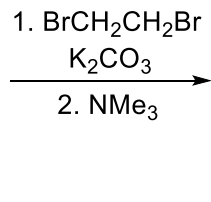

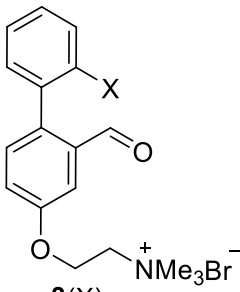
$3(\mathrm{X})$

Scheme S2. General Synthetic routes of water soluble compounds $\mathbf{3}(\mathrm{X})$ and $\mathbf{5 .}$<smiles>COc1ccccc1-c1ccc(OCCN(C)Br)cc1C=O</smiles>

2-((2-formyl-2'-methoxy-[1,1'-biphenyl]-4-yl)oxy)- $N, N, N$ -

trimethylethan-1-aminium bromide: To a suspension of 4-hydroxy-2'-methoxy-[1,1'-biphenyl]-2-carbaldehyde (1.0 mmol, $228 \mathrm{mg})$ and potassium carbonate $(3.0 \mathrm{mmol}, 414 \mathrm{mg})$ in $10 \mathrm{ml}$ anhydrous DMF, was added 1,2-dibromoethane $(2.0 \mathrm{mmol}, 376 \mathrm{mg}$ ) was added dropwise. The reaction was stirred at $90{ }^{\circ} \mathrm{C}$ until the starting material was completely consumed. After the reaction was cooled to room temperature, $\mathrm{H}_{2} \mathrm{O}(50 \mathrm{~mL})$ was added, and the mixture was extracted 
with EA $(25 \mathrm{ml} \times 3)$. The combined organic layer was washed with brine $(50 \mathrm{ml} \times 3)$, dried over anhydrous $\mathrm{Na}_{2} \mathrm{SO}_{4}$, and concentrated under vacuum. Toluene $(7 \mathrm{~mL})$, a solution of trimethylamine ( $2 \mathrm{M}$ in THF, $3 \mathrm{~mL}$ ) was added to the resulting residue, and the mixture was transferred to a sealed tube. The reaction was stirred at $60{ }^{\circ} \mathrm{C}$ for 2 days, and $\mathrm{H}_{2} \mathrm{O}(20 \mathrm{~mL})$ was next added. The aqueous layer was washed with $\mathrm{PE}$ $(20 \mathrm{ml} \times 3)$ and EA $(20 \mathrm{ml} \times 3)$, concentrated under vacuum, and dried to afford the title compound as a white solid (389 mg, 96\%). ${ }^{1} \mathrm{H}$ NMR $\left(\mathrm{D}_{2} \mathrm{O}\right): \delta 9.57(\mathrm{~s}, 1 \mathrm{H})$, 7.50-7.47 (m, 2H), 7.37-7.30 (m, 3H), 7.15 (t, $J=6.6 \mathrm{~Hz}, 2 \mathrm{H}), 4.58(\mathrm{br}, 2 \mathrm{H}), 3.85$ (t, $J$ $=4.5 \mathrm{~Hz}, 2 \mathrm{H}), 3.71(\mathrm{~s}, 3 \mathrm{H}), 3.26(\mathrm{~s}, 9 \mathrm{H}) .{ }^{13} \mathrm{C} \mathrm{NMR}\left(\mathrm{D}_{2} \mathrm{O}\right): \delta 194.9,156.7,155.8$, $134.8,134.2,132.8,131.1,130.2,125.6,121.5,121.3,111.5,111.3,64.9,62.1,55.2$, 54.0. ESI-HRMS: $\mathrm{m} / \mathrm{z}$ calcd for $\mathrm{C}_{19} \mathrm{H}_{24} \mathrm{NO}_{3}{ }^{+}\left[\mathrm{M}^{+}\right]$: 314.1751 ; found: 314.1751 .

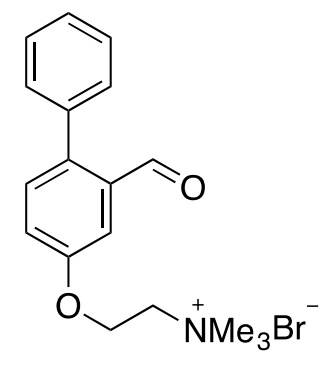

2-((2-formyl-[1,1'-biphenyl]-4-yl)oxy)- $N, N, N$-trimethylethan-

1-aminium bromide: To a suspension of 4-hydroxy-[1,1'-biphenyl]-2-carbaldehyde $(1.0 \mathrm{mmol}, 198 \mathrm{mg})$ and potassium carbonate $(3.0 \mathrm{mmol}, 414 \mathrm{mg})$ in $10 \mathrm{ml}$ anhydrous DMF, was added 1,2-dibromoethane $(2.0 \mathrm{mmol}, 376 \mathrm{mg})$ was added dropwise. The reaction was stirred at $90{ }^{\circ} \mathrm{C}$ until the starting material was completely consumed. After the reaction was cooled to room temperature, $\mathrm{H}_{2} \mathrm{O}(50 \mathrm{~mL})$ was added, and the mixture was extracted with EA $(25 \mathrm{ml} \times 3)$. The combined organic layer was washed with brine $(50 \mathrm{ml} \times 3)$, dried over anhydrous $\mathrm{Na}_{2} \mathrm{SO}_{4}$, and concentrated under vacuum. Toluene $(7 \mathrm{~mL})$, a solution of trimethylamine $(2 \mathrm{M}$ in THF, $3 \mathrm{~mL})$ was added to the resulting residue, and the mixture was transferred to a sealed tube. The reaction was stirred at $60{ }^{\circ} \mathrm{C}$ for 2 days, and $\mathrm{H}_{2} \mathrm{O}(20 \mathrm{~mL})$ was next added. The aqueous layer was washed with PE $(20 \mathrm{ml} \times 3)$ and EA $(20 \mathrm{ml} \times 3)$, concentrated under vacuum, and dried to afford the title compound as a yellowish solid (360 mg, 95\%). ${ }^{1} \mathrm{H}$ NMR $\left(\mathrm{D}_{2} \mathrm{O}\right): \delta 9.73(\mathrm{~s}, 1 \mathrm{H}), 7.50-7.43(\mathrm{~m}, 5 \mathrm{H}), 7.36-7.31(\mathrm{~m}, 3 \mathrm{H}), 4.53$ (br, 2H), 3.83 (br, 
$2 \mathrm{H}), 3.24(\mathrm{~s}, 9 \mathrm{H}) .{ }^{13} \mathrm{C} \mathrm{NMR}\left(\mathrm{D}_{2} \mathrm{O}\right): \delta 193.9,156.5,139.4,136.7,133.5,132.3,130.0$, 128.4, 127.9, 121.4, 111.7, 64.9, 62.1, 54.0. ESI-HRMS: $\mathrm{m} / \mathrm{z}$ calcd for $\mathrm{C}_{18} \mathrm{H}_{22} \mathrm{NO}_{2}{ }^{+}$ $\left[\mathrm{M}^{+}\right]:$284.1645; found: 284.1645 .<smiles>COc1ccccc1-c1ccc(O)cc1C=O</smiles>

4-hydroxy-2'-methoxy-[1,1'-biphenyl]-2-carbaldehyde: The reported procedure $^{\mathrm{S} 7}$ was used to afford the title compound as a white solid (yield: $90 \%$ ). ${ }^{1} \mathrm{H}$ NMR (DMSO-d 6 ): $\delta 9.98(\mathrm{br}, 1 \mathrm{H}), 9.55(\mathrm{~s}, 1 \mathrm{H}), 7.40(\mathrm{t}, J=8.1 \mathrm{~Hz}, 1 \mathrm{H}), 7.25(\mathrm{~d}, J=$ 7.2 Hz, 1H), 7.21-7.18 (m, 2H), 7.12-7.05 (m, 3H), 3.67 (s, 3H).<smiles>O=Cc1cc(O)ccc1-c1ccccc1</smiles>

4-hydroxy-[1,1'-biphenyl]-2-carbaldehyde: The reported procedure ${ }^{\mathrm{S} 8}$ was used to afford the title compound as a yellowish solid (yield: 92\%). ${ }^{1} \mathrm{H}$ NMR (DMSO-d $): \delta 10.05$ (br, 1H), $9.81(\mathrm{~s}, 1 \mathrm{H}), 7.50-7.41(\mathrm{~m}, 3 \mathrm{H}), 7.41-7.36(\mathrm{~m}, 3 \mathrm{H})$, $7.35-7.28(\mathrm{~m}, 2 \mathrm{H}), 7.16(\mathrm{dd}, J=8.2,2.2 \mathrm{~Hz}, 1 \mathrm{H})$.

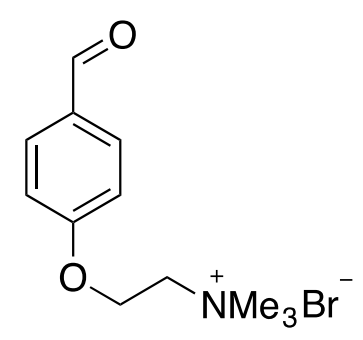

\section{2-(4-formylphenoxy)- $N, N, N$-trimethylethan-1-aminium}

bromide: The reported procedure ${ }^{\mathrm{S} 9}$ was used to afford the title compound as a white solid (yield: 98\%). ${ }^{1} \mathrm{H}$ NMR ( $\left.\mathrm{D}_{2} \mathrm{O}\right): \delta 9.77(\mathrm{~s}, 1 \mathrm{H}), 7.93$ (d, $\left.J=8.5 \mathrm{~Hz}, 2 \mathrm{H}\right), 7.16(\mathrm{~d}, J$ $=8.4 \mathrm{~Hz}, 2 \mathrm{H}), 4.61(\mathrm{br}, 2 \mathrm{H}), 3.86(\mathrm{t}, J=4.1 \mathrm{~Hz}, 2 \mathrm{H}), 3.24(\mathrm{~s}, 9 \mathrm{H})$.

\section{(3) NMR spectrum of synthetic compounds}



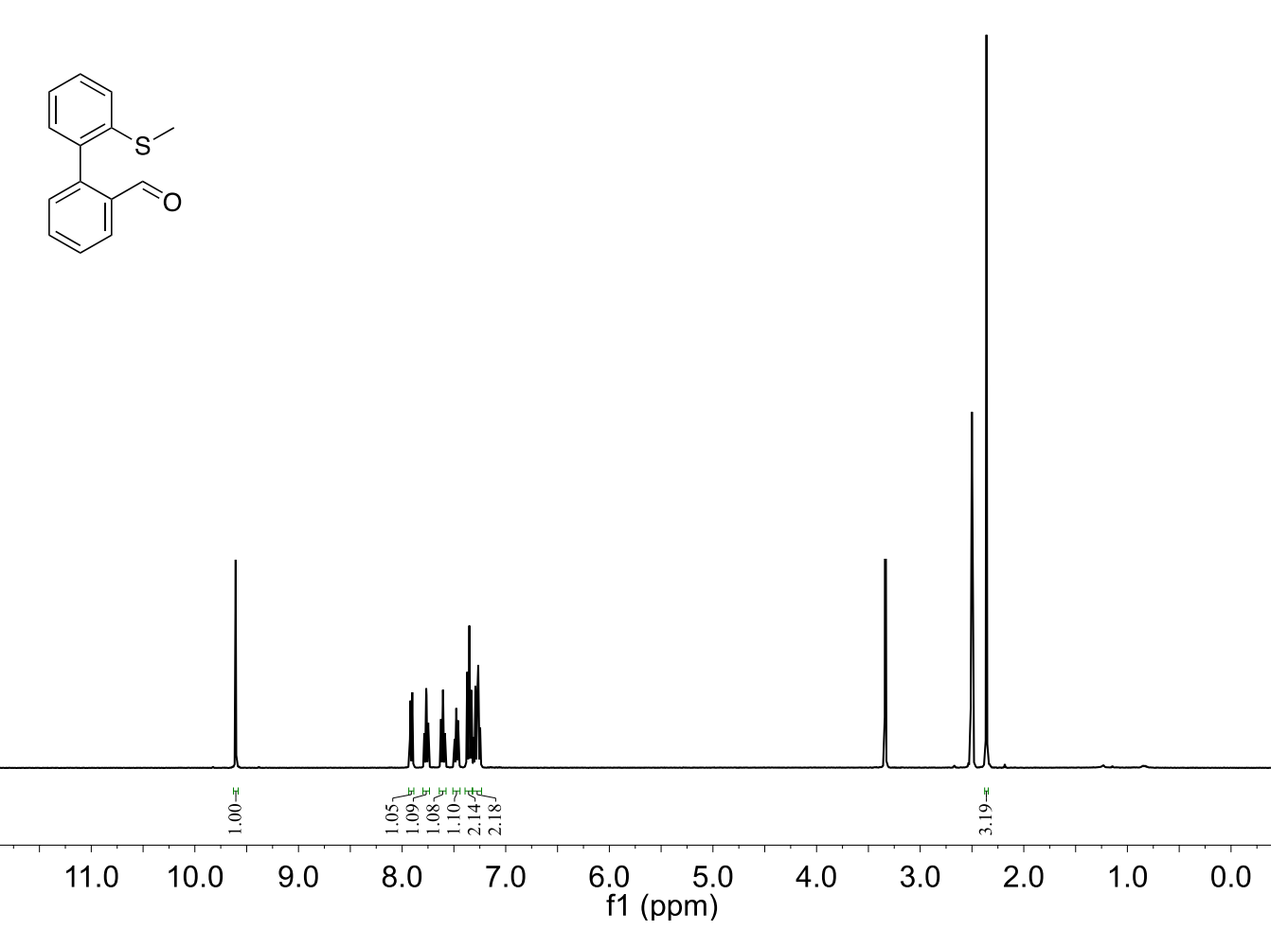

Figure S1. ${ }^{1} \mathrm{H}$ NMR spectrum of $\mathbf{1}(\mathrm{SMe})$ in DMSO-d 6 .

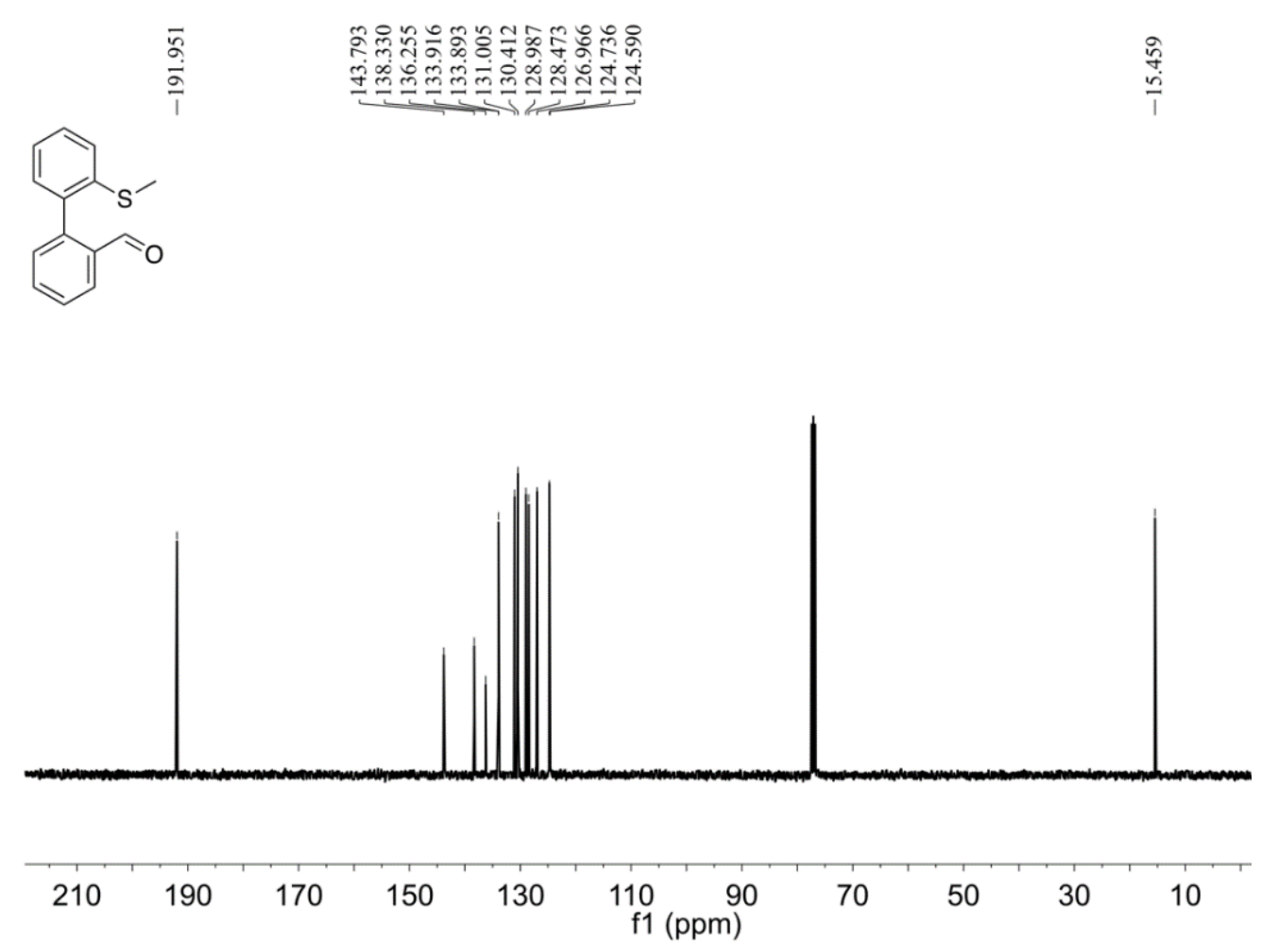

Figure S2. ${ }^{13} \mathrm{C}$ NMR spectrum of $\mathbf{1}(\mathrm{SMe})$ in $\mathrm{CDCl}_{3}$. 


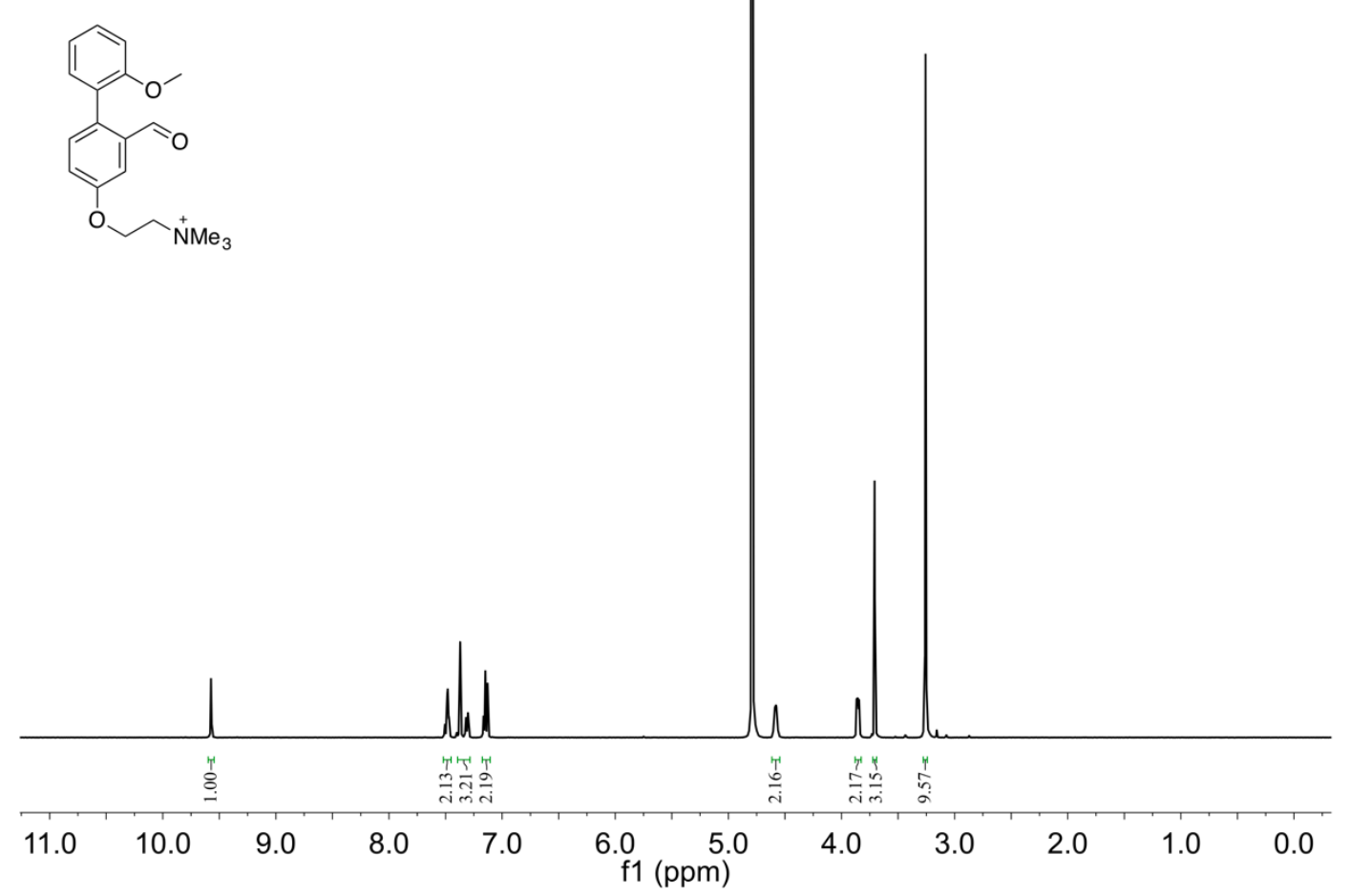

Figure S3. ${ }^{1} \mathrm{H}$ NMR spectrum of $\mathbf{3}(\mathrm{OMe})$ in $\mathrm{D}_{2} \mathrm{O}$.
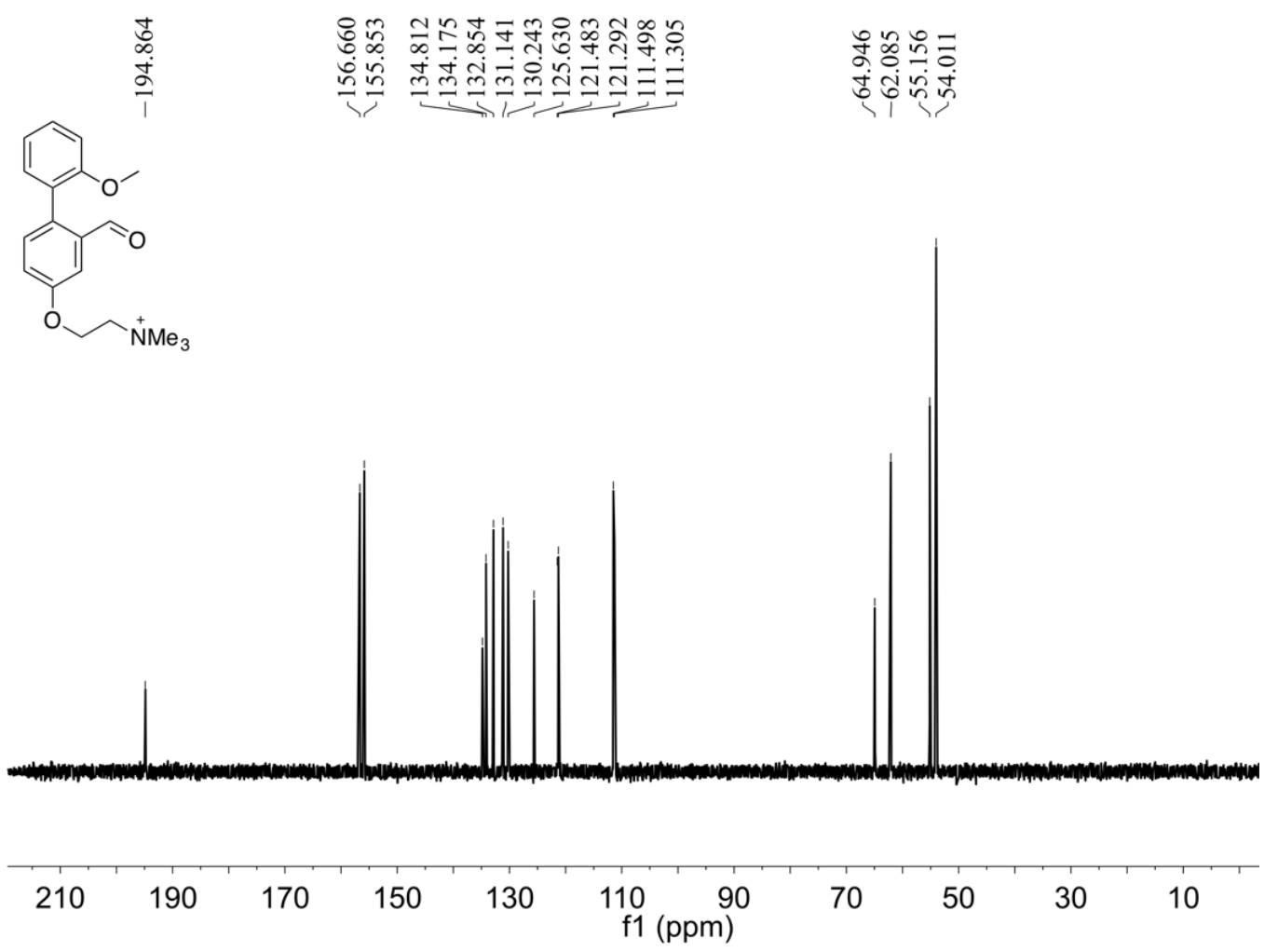

Figure S4. ${ }^{13} \mathrm{C}$ NMR spectrum of $\mathbf{3}(\mathrm{OMe})$ in $\mathrm{D}_{2} \mathrm{O}$. 

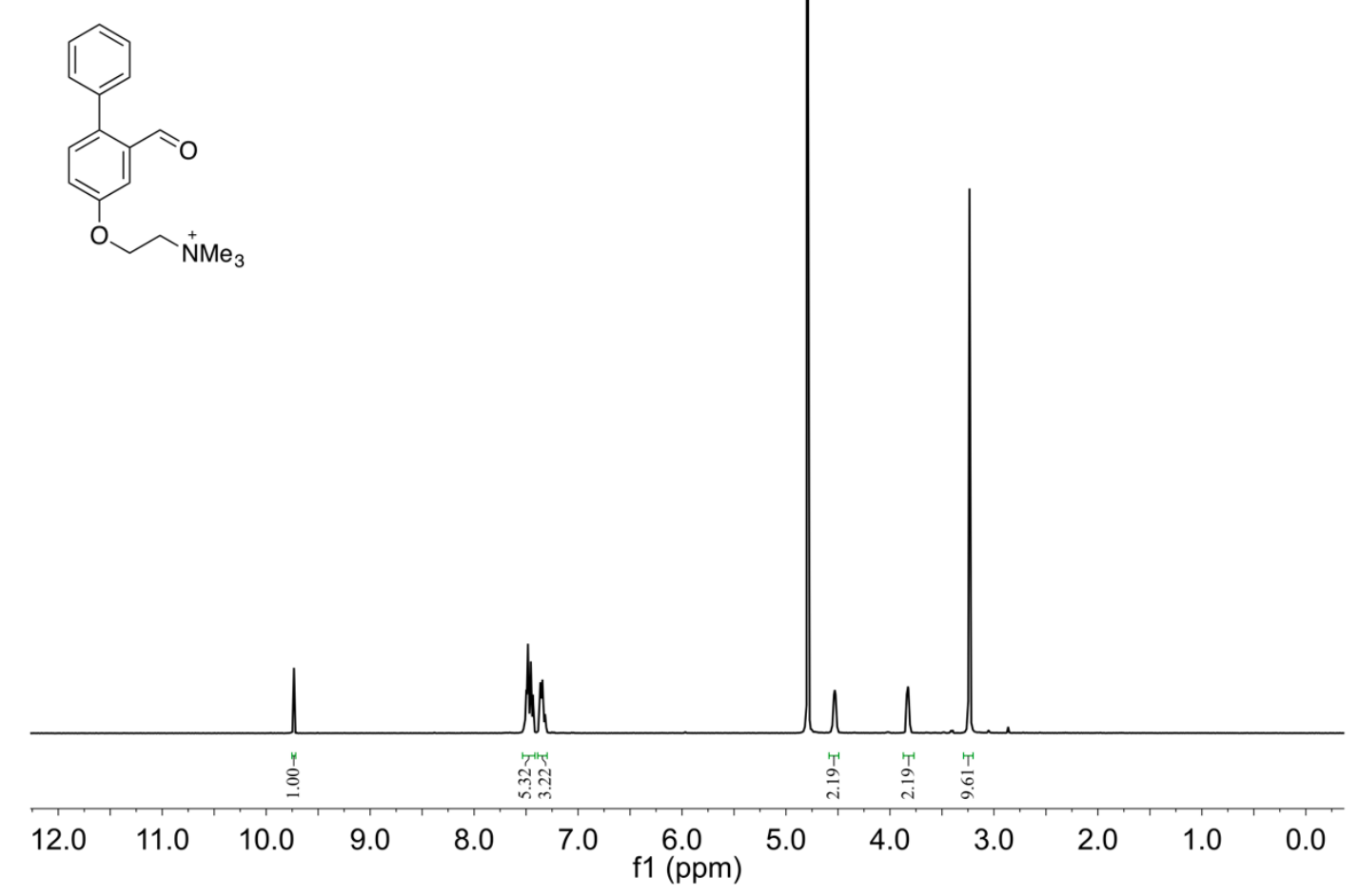

Figure S5. ${ }^{1} \mathrm{H}$ NMR spectrum of $\mathbf{3}(\mathrm{H})$ in $\mathrm{D}_{2} \mathrm{O}$.

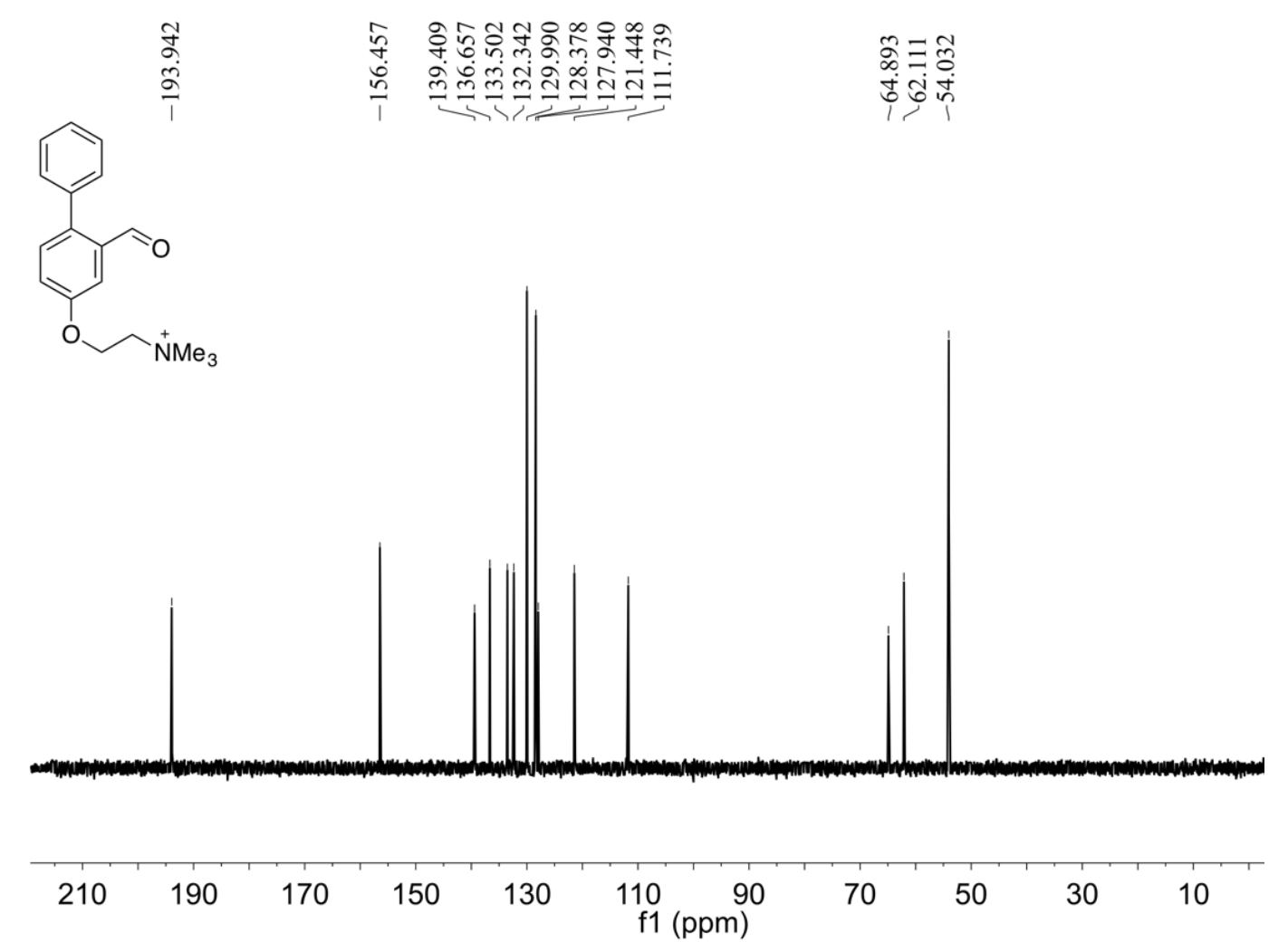

Figure S6. ${ }^{13} \mathrm{C}$ NMR spectrum of $\mathbf{3}(\mathrm{H})$ in $\mathrm{D}_{2} \mathrm{O}$. 


\section{(4) Crystal structures of $1(X)$}

a<smiles>COc1ccccc1-c1ccccc1C=O</smiles>

b

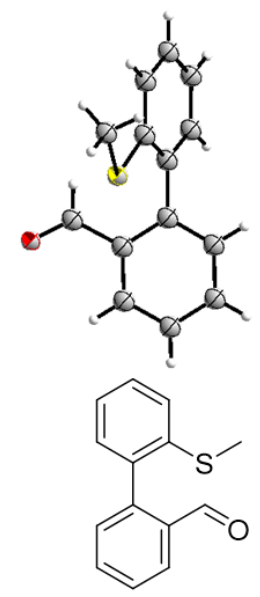

Figure S7. Crystal structure of 1(OMe) (a) and 1(SMe) (b).

Table S1. Summary of crystallographic data for $\mathbf{1}(\mathrm{OMe})$ and $\mathbf{1}(\mathrm{SMe})$.

\begin{tabular}{|c|c|c|}
\hline & $\mathbf{1}(\mathrm{OMe})$ & $\mathbf{1}(\mathrm{SMe})$ \\
\hline Formula & $\mathrm{C}_{14} \mathrm{H}_{12} \mathrm{O}_{2}$ & $\mathrm{C}_{14} \mathrm{H}_{12} \mathrm{OS}$ \\
\hline Formula weight & 212.24 & 228.30 \\
\hline $\mathrm{T} / \mathrm{K}$ & 100 & 293 \\
\hline Crystallization solvent & Cyclohexane & Cyclohexane \\
\hline Color & Colorless & Colorless \\
\hline Crystal system & monoclinic & monoclinic \\
\hline Space group & P 1211 & P $121 / \mathrm{c} 1$ \\
\hline$a / \AA$ & $7.6256(4)$ & $10.530(4)$ \\
\hline$b / \AA$ & $7.4766(3)$ & $7.555(3)$ \\
\hline$c / \AA$ & $9.9777(5)$ & $15.466(6)$ \\
\hline$\alpha /^{\circ}$ & 90.00 & 90.00 \\
\hline$\beta /{ }^{\circ}$ & $108.663(2)$ & $105.601(5)$ \\
\hline$\gamma /{ }^{\circ}$ & 90.00 & 90.00 \\
\hline$V / \AA^{3}$ & $538.95(4)$ & $1185.1(8)$ \\
\hline$Z$ & 2 & 4 \\
\hline$D_{\mathrm{x}} / \mathrm{g} \mathrm{cm}^{-3}$ & 1.308 & 1.280 \\
\hline$\mu / \mathrm{mm}^{-1}$ & 0.087 & 0.247 \\
\hline$F(000)$ & 224.0 & 480.0 \\
\hline$\theta$ range $/{ }^{\circ}$ & 2.950 to 25.414 & 2.7167 to 27.5126 \\
\hline GOF on $\mathrm{F}^{2}$ & 1.294 & 1.049 \\
\hline$R_{1}[I>2 \sigma(I)]$ & 0.0269 & 0.0359 \\
\hline$w R_{2}$ (all data) & 0.0970 & 0.1029 \\
\hline
\end{tabular}




\section{Dynamic Covalent Reactions}

Dynamic Covalent Reactions (DCRs) were performed in situ in $\mathrm{CD}_{3} \mathrm{CN}$ without isolation and purification. To a stirred solution of 1 (20 mM, 1.0 equiv.) in $\mathrm{CD}_{3} \mathrm{CN}$ $(0.60 \mathrm{~mL})$, were added 1-butylamine ( $22 \mathrm{mM}, 1.2$ equiv.) and activated $3 \AA$ molecular sieves (MS, 4-8 mesh). The mixture was stirred at room temperature overnight and characterized by ${ }^{1} \mathrm{H}$ NMR and ESI-MS. For imine exchange, another aldehyde (20 $\mathrm{mM}, 1.0$ equiv.) was then added, and the exchange was monitored by ${ }^{1} \mathrm{H}$ NMR. For competition experiments, both aldehydes (20 mM each, 1.0 equiv.) were mixed with 1-butylamine (24 mM, 1.2 equiv.) in $\mathrm{CD}_{3} \mathrm{CN}(0.60 \mathrm{~mL})$, and the mixture was stirred overnight and characterized by ${ }^{1} \mathrm{H}$ NMR. To ensure reproducibility all competition experiments were performed twice.

\section{(1) Imine formation}

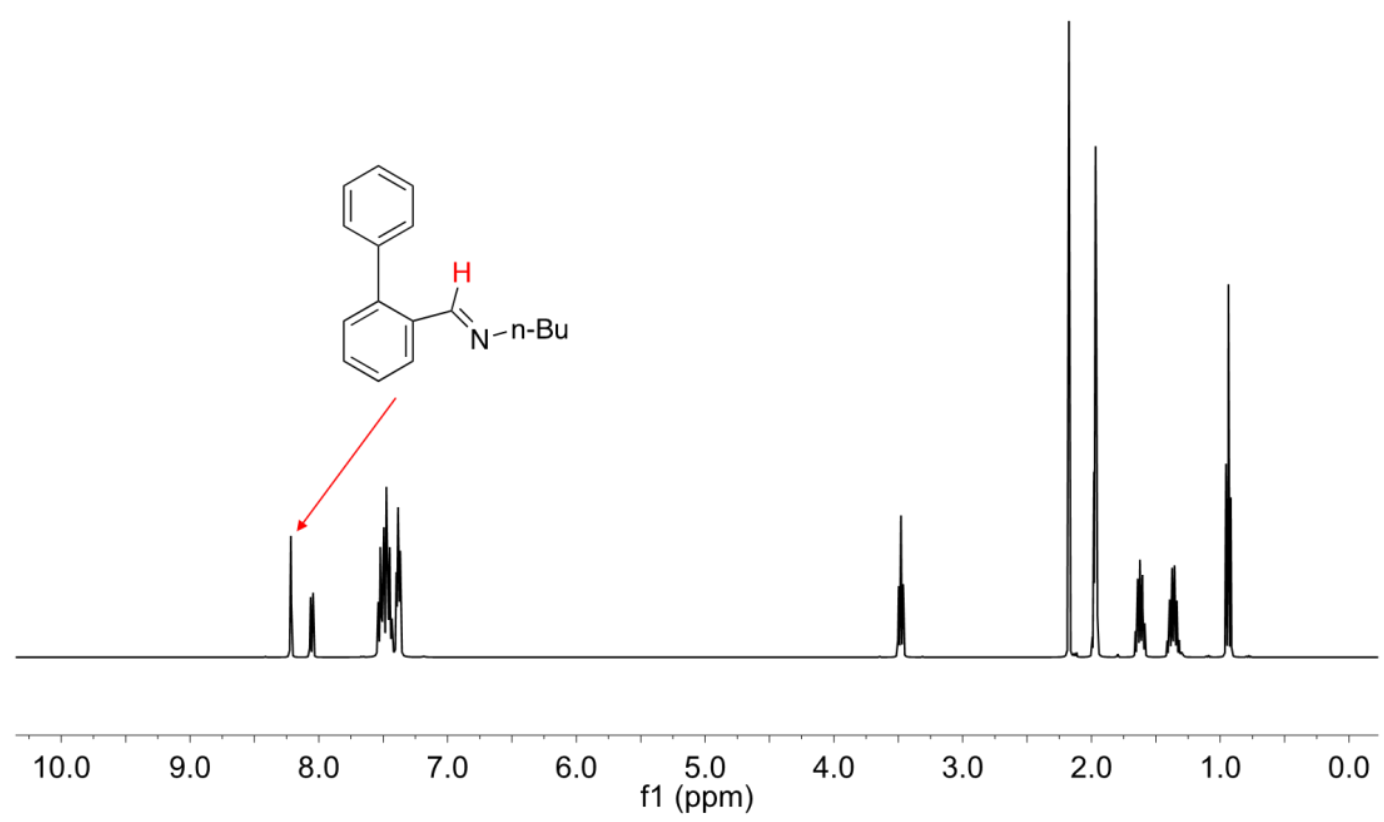

Figure S8. ${ }^{1} \mathrm{H}$ NMR spectrum of the reaction of $1(\mathrm{H})$ and 1-butylamine in $\mathrm{CD}_{3} \mathrm{CN}$. 


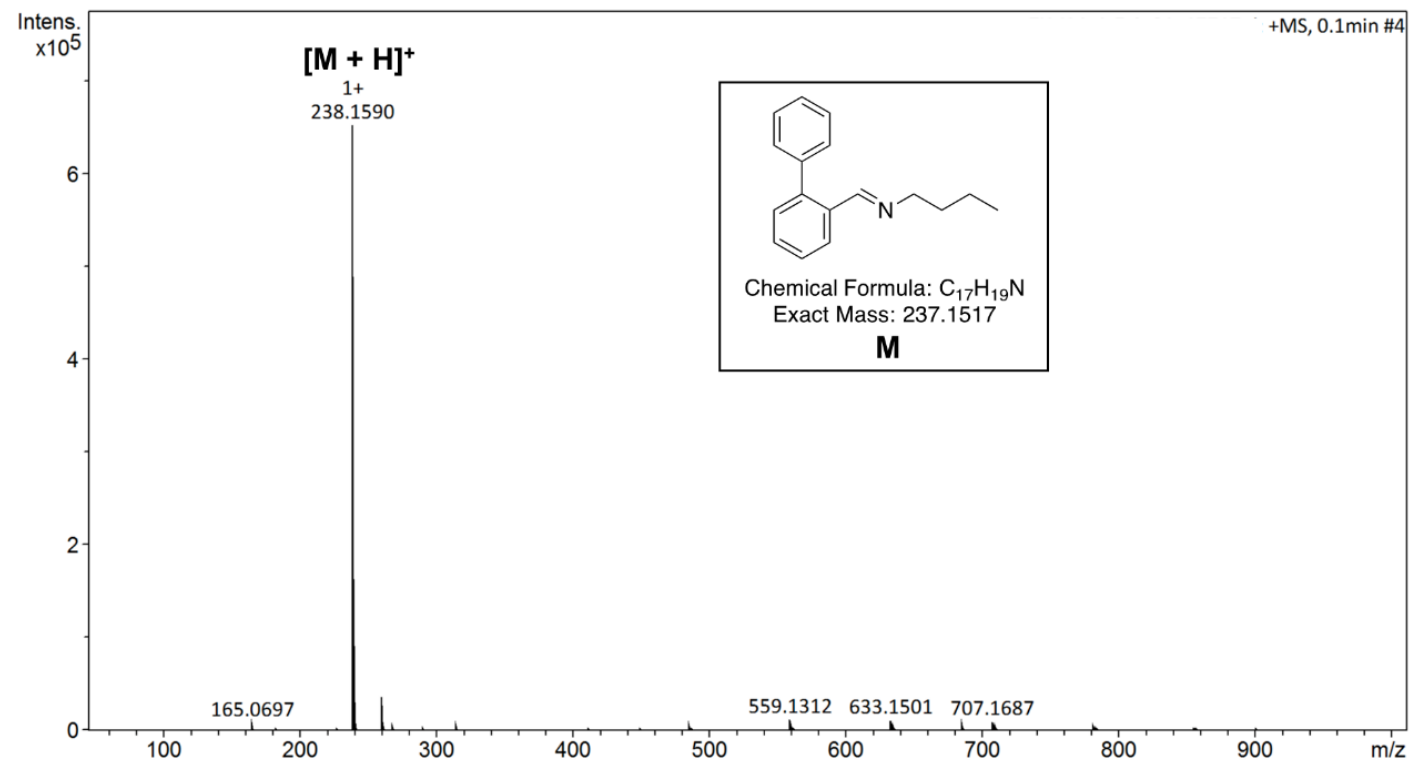

Figure S9. ESI-MS spectrum of the reaction of $\mathbf{1}(\mathrm{H})$ and 1-butylamine in $\mathrm{CD}_{3} \mathrm{CN}$.

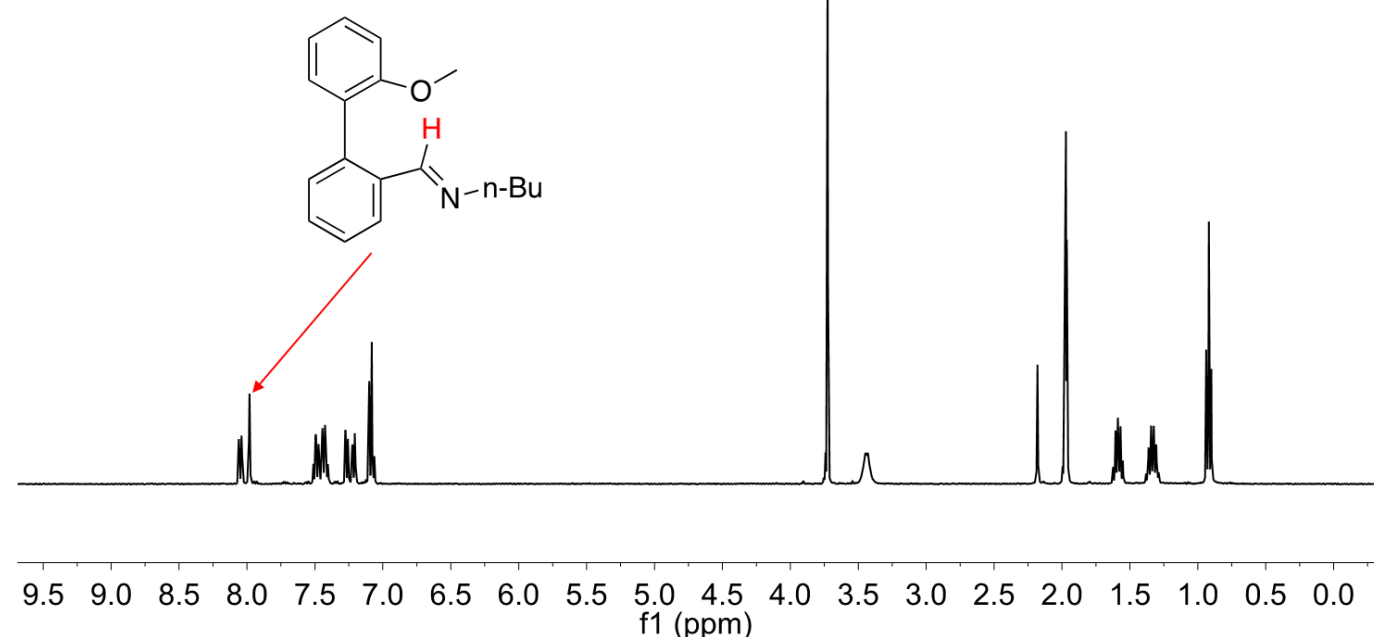

Figure S10. ${ }^{1} \mathrm{H}$ NMR spectrum of the reaction of $1(\mathrm{OMe})$ and 1-butylamine in $\mathrm{CD}_{3} \mathrm{CN}$. 


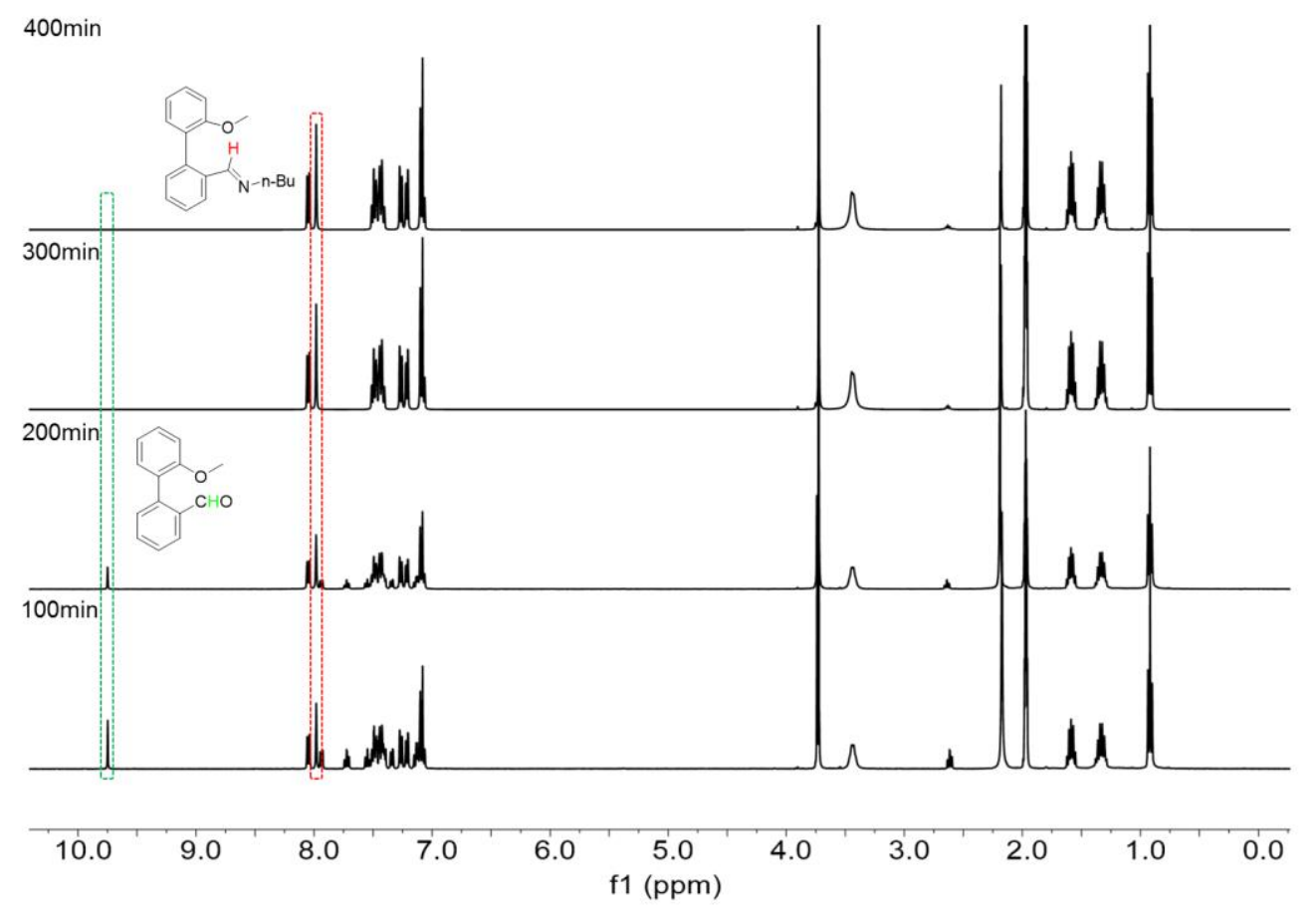

Figure S11. ${ }^{1} \mathrm{H}$ NMR spectra of the reaction between $1(\mathrm{OMe})(20 \mathrm{mM}, 1.0$ equiv.) and 1-butylamine (24 mM, 1.2 equiv.) in $\mathrm{CD}_{3} \mathrm{CN}$ at varied time. The reaction was complete in $300 \mathrm{~min}$.

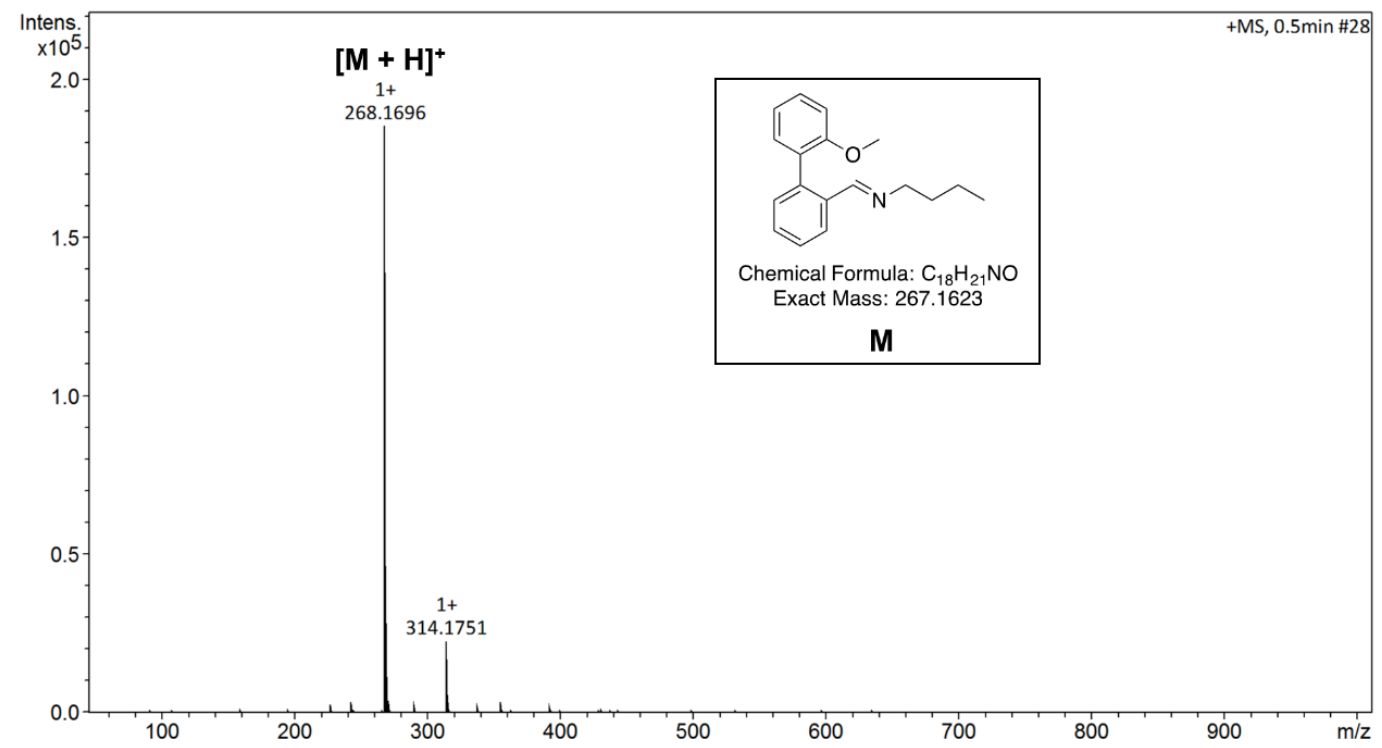

Figure S12. ESI-MS spectrum of the reaction of $1(\mathrm{OMe})$ and 1-butylamine in $\mathrm{CD}_{3} \mathrm{CN}$. 


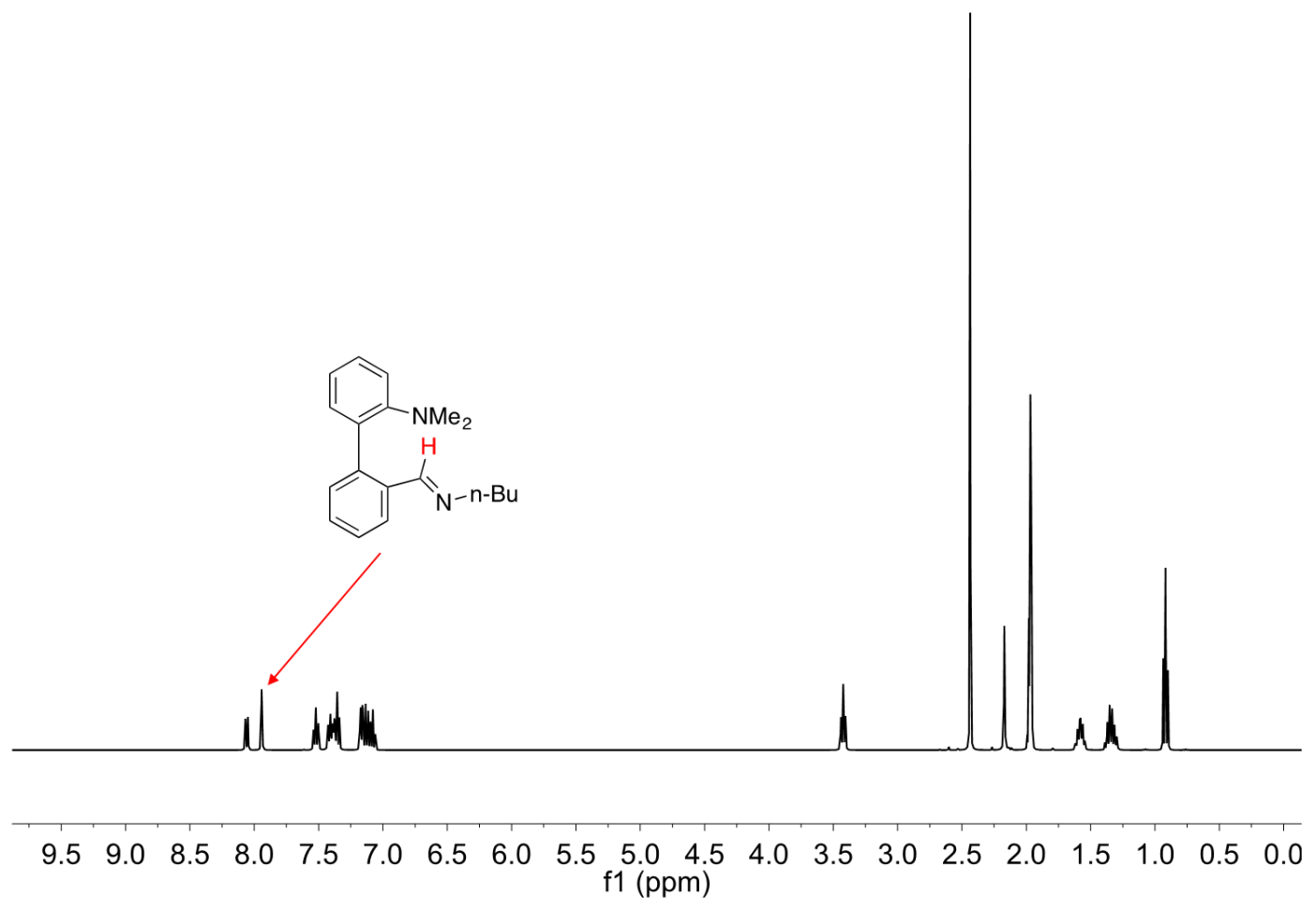

Figure S13. ${ }^{1} \mathrm{H}$ NMR spectrum of the reaction of $1\left(\mathrm{NMe}_{2}\right)$ and 1-butylamine in $\mathrm{CD}_{3} \mathrm{CN}$.

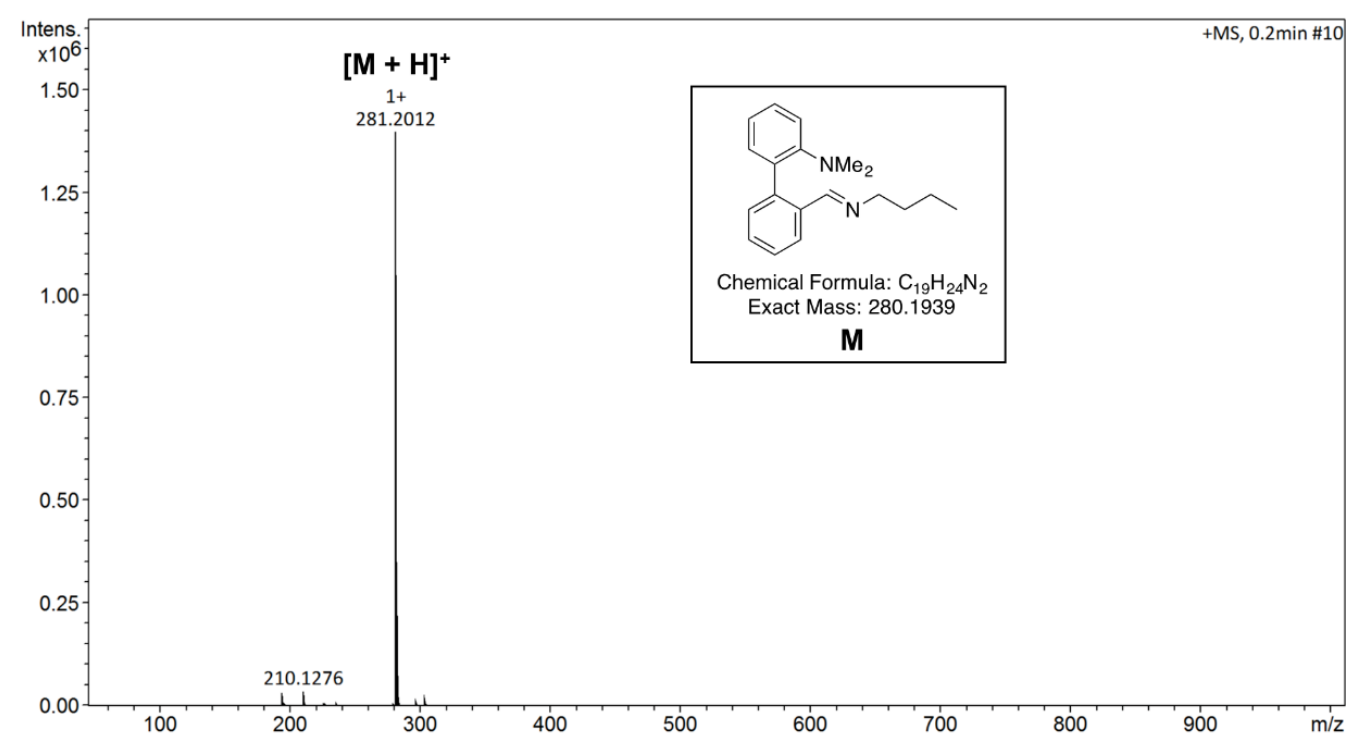

Figure S14. ESI-MS spectrum of the reaction of $1\left(\mathrm{NMe}_{2}\right)$ and 1-butylamine in $\mathrm{CD}_{3} \mathrm{CN}$. 


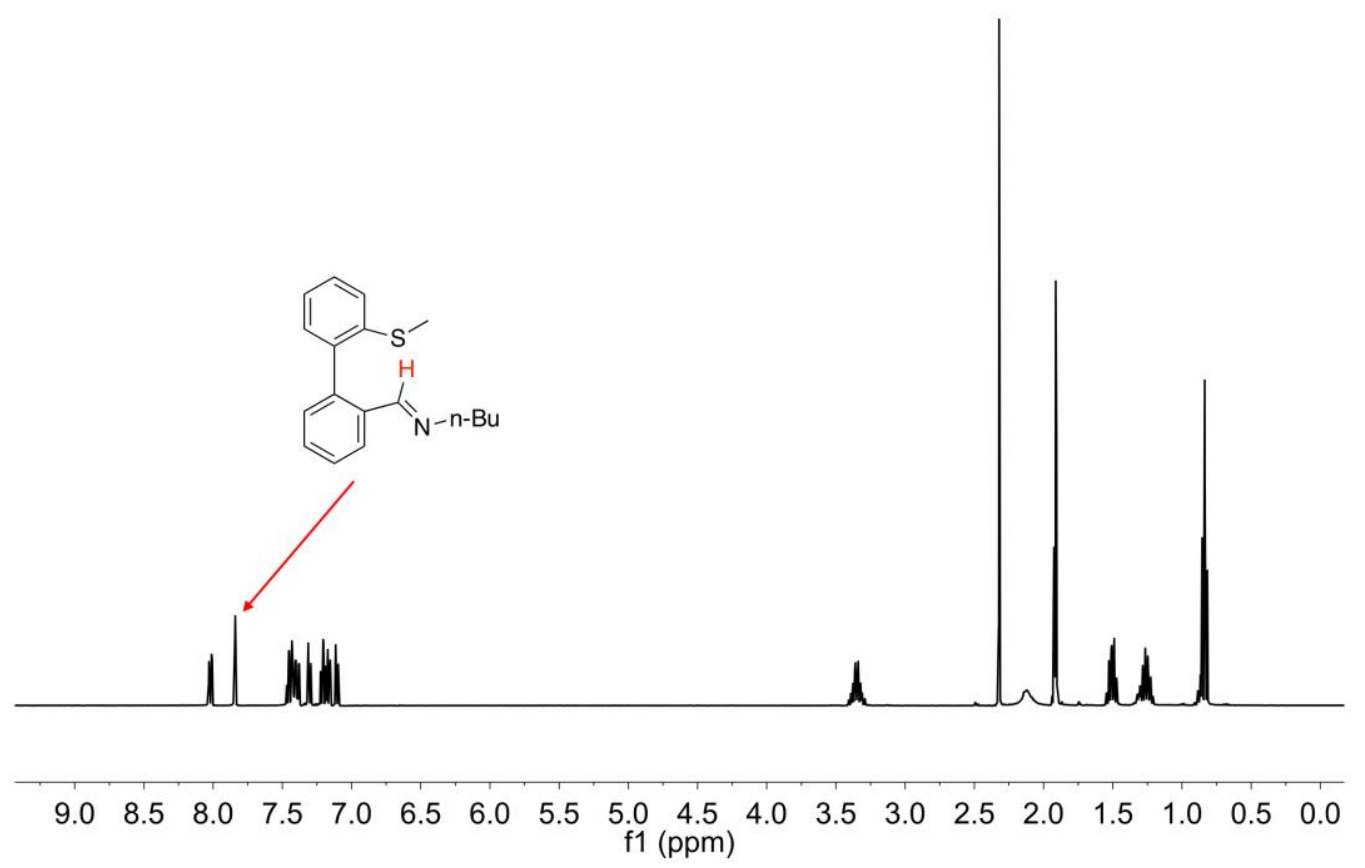

Figure S15. ${ }^{1} \mathrm{H}$ NMR spectrum of the reaction of $\mathbf{1}(\mathrm{SMe})$ and 1-butylamine in $\mathrm{CD}_{3} \mathrm{CN}$.

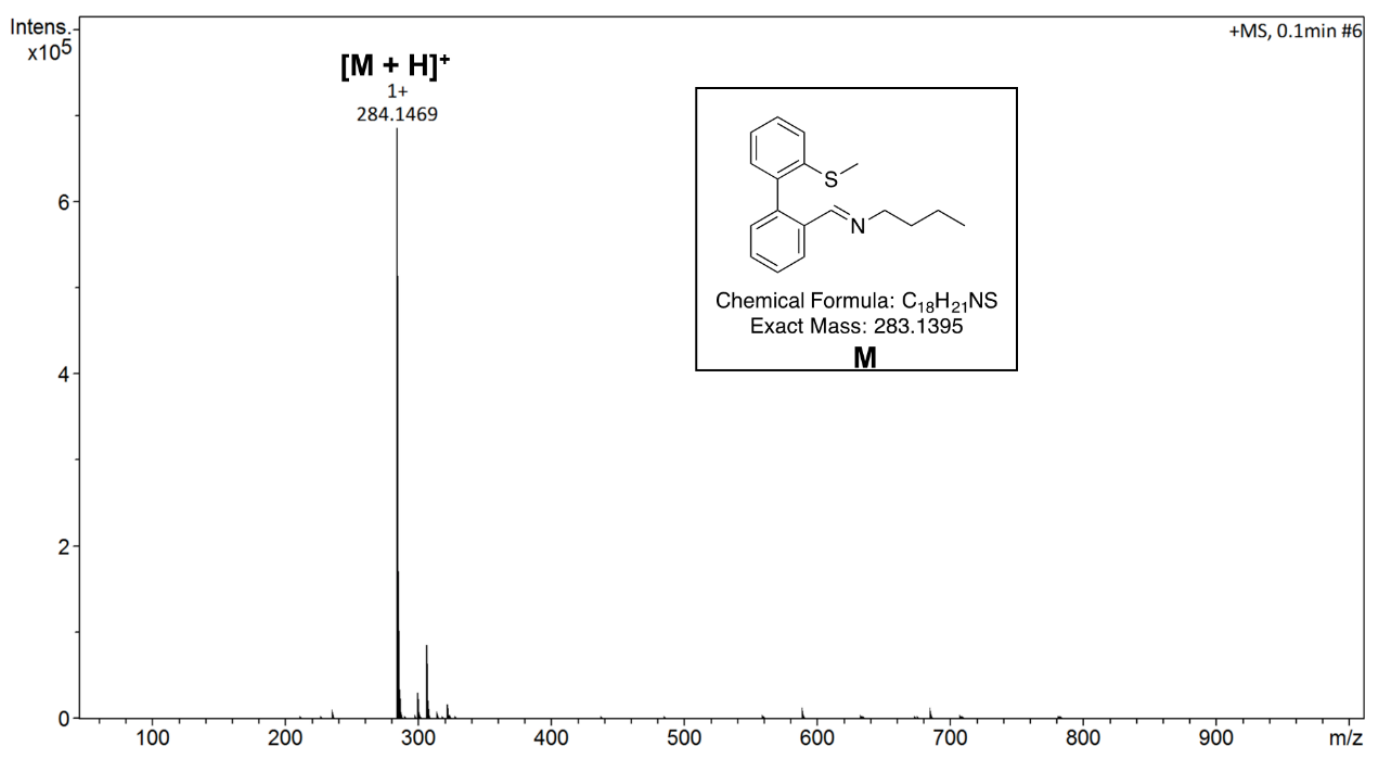

Figure S16. ESI-MS spectrum of the reaction of $1(\mathrm{SMe})$ and 1-butylamine in $\mathrm{CD}_{3} \mathrm{CN}$. 


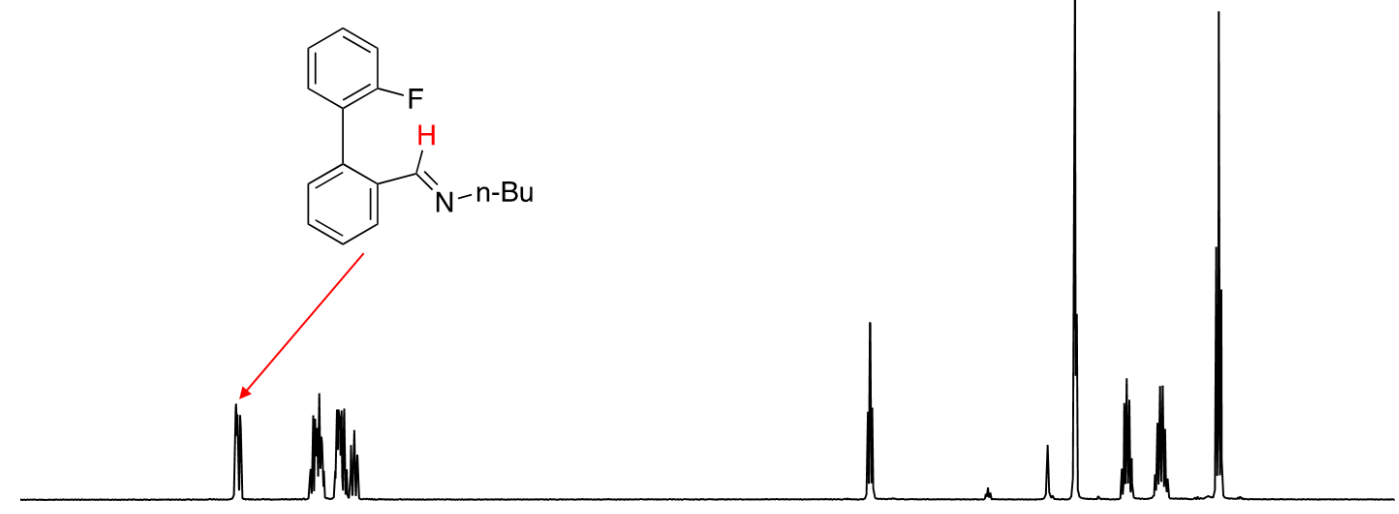

$\begin{array}{lllllllllllllllllllll}9.5 & 9.0 & 8.5 & 8.0 & 7.5 & 7.0 & 6.5 & 6.0 & 5.5 & \begin{array}{c}5.0 \\ \mathrm{f} 1(\mathrm{ppm})\end{array} & 4.5 & 4.0 & 3.5 & 3.0 & 2.5 & 2.0 & 1.5 & 1.0 & 0.5 & 0.0\end{array}$

Figure S17. ${ }^{1} \mathrm{H}$ NMR spectrum of the reaction of $1(\mathrm{~F})$ and 1-butylamine in $\mathrm{CD}_{3} \mathrm{CN}$.

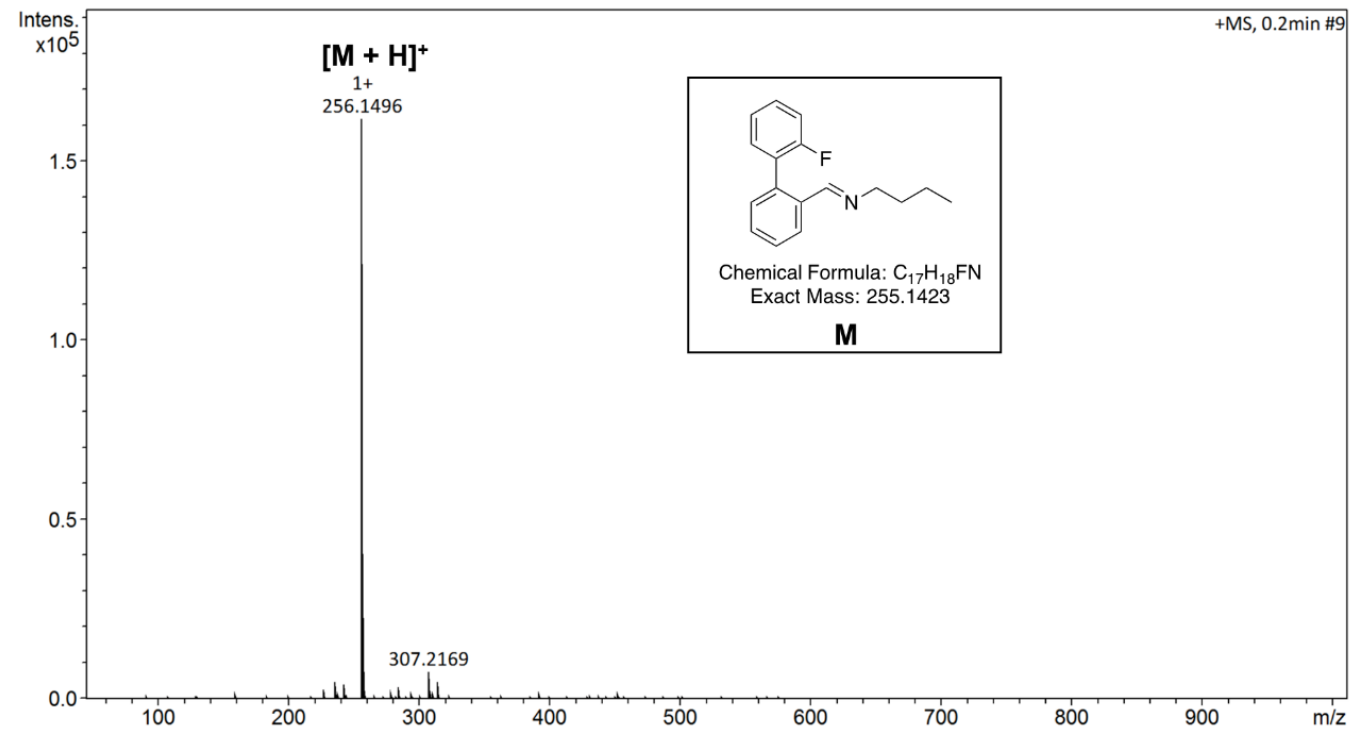

Figure S18. ESI-MS spectrum of the reaction of $1(\mathrm{~F})$ and 1-butylamine in $\mathrm{CD}_{3} \mathrm{CN}$. 


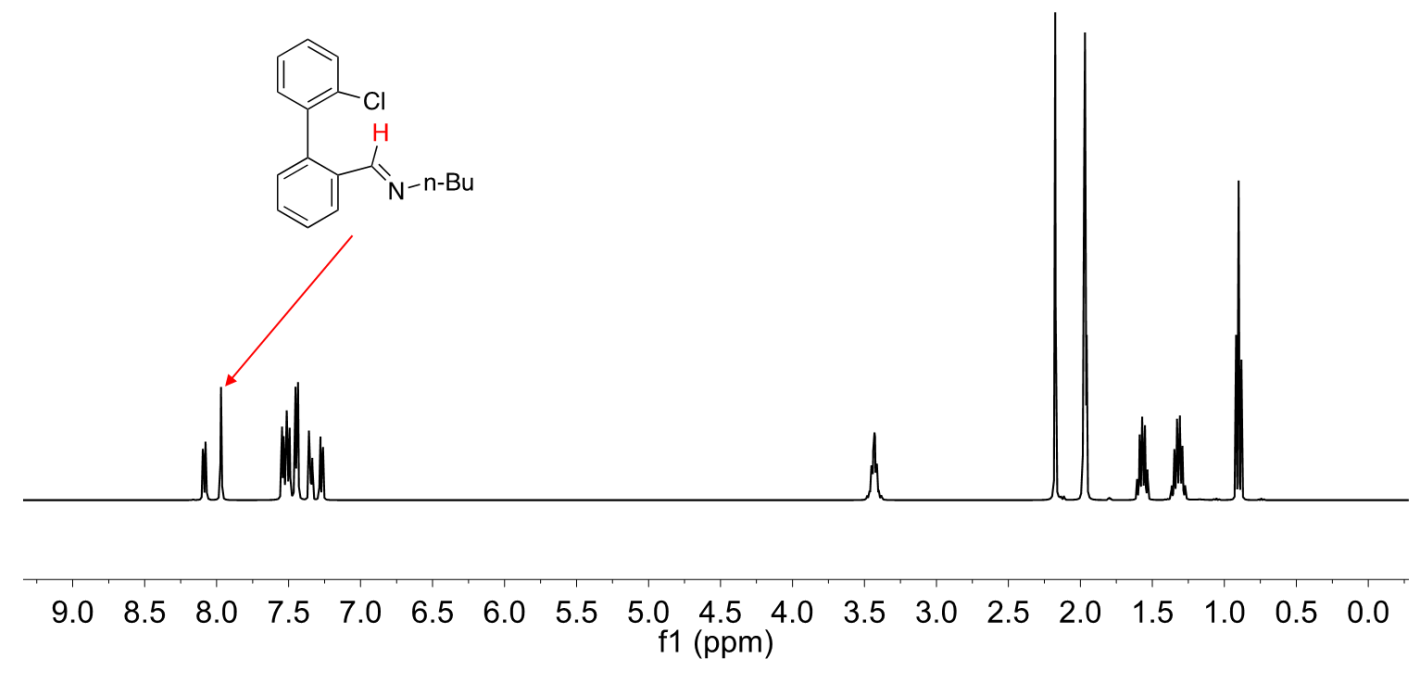

Figure S19. ${ }^{1} \mathrm{H}$ NMR spectrum of the reaction of $1(\mathrm{Cl})$ and 1-butylamine in $\mathrm{CD}_{3} \mathrm{CN}$.

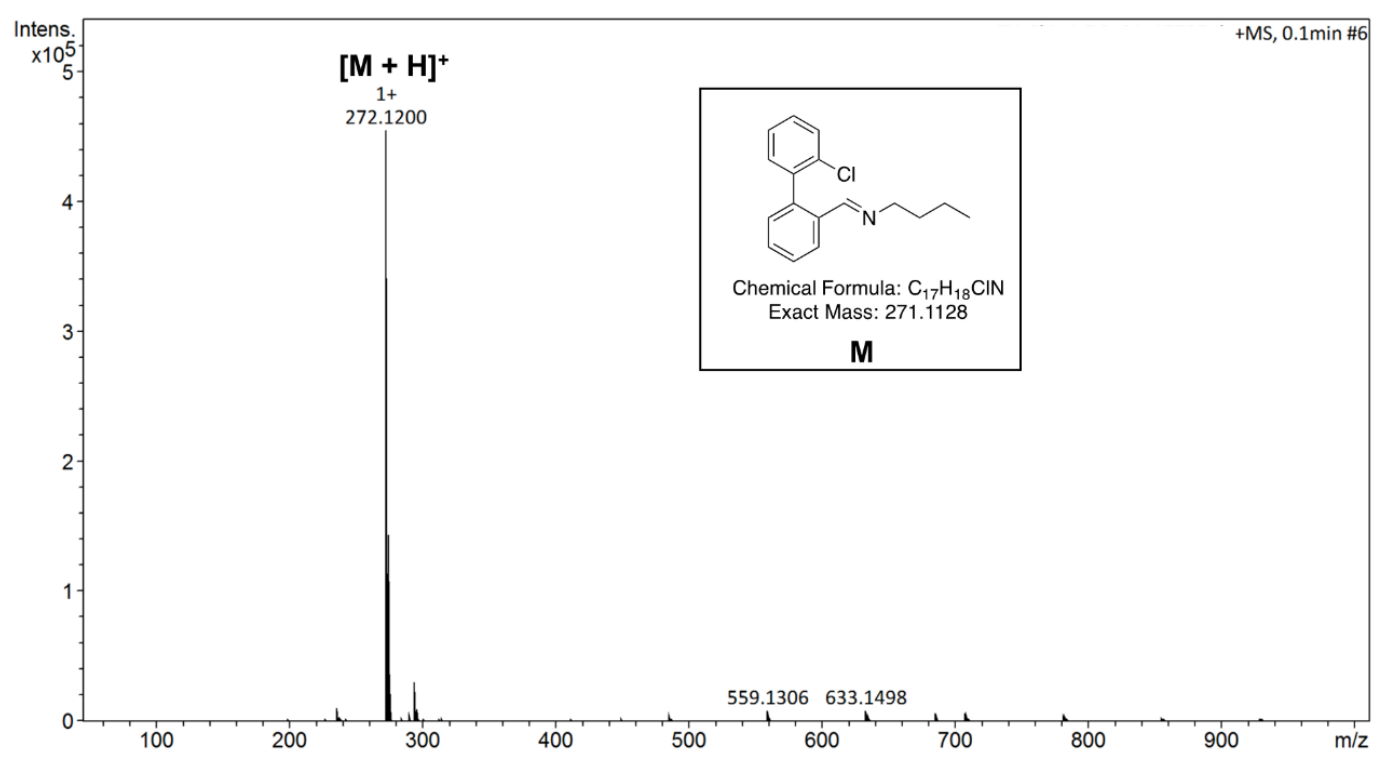

Figure S20. ESI-MS spectrum of the reaction of $1(\mathrm{Cl})$ and 1-butylamine in $\mathrm{CD}_{3} \mathrm{CN}$. 


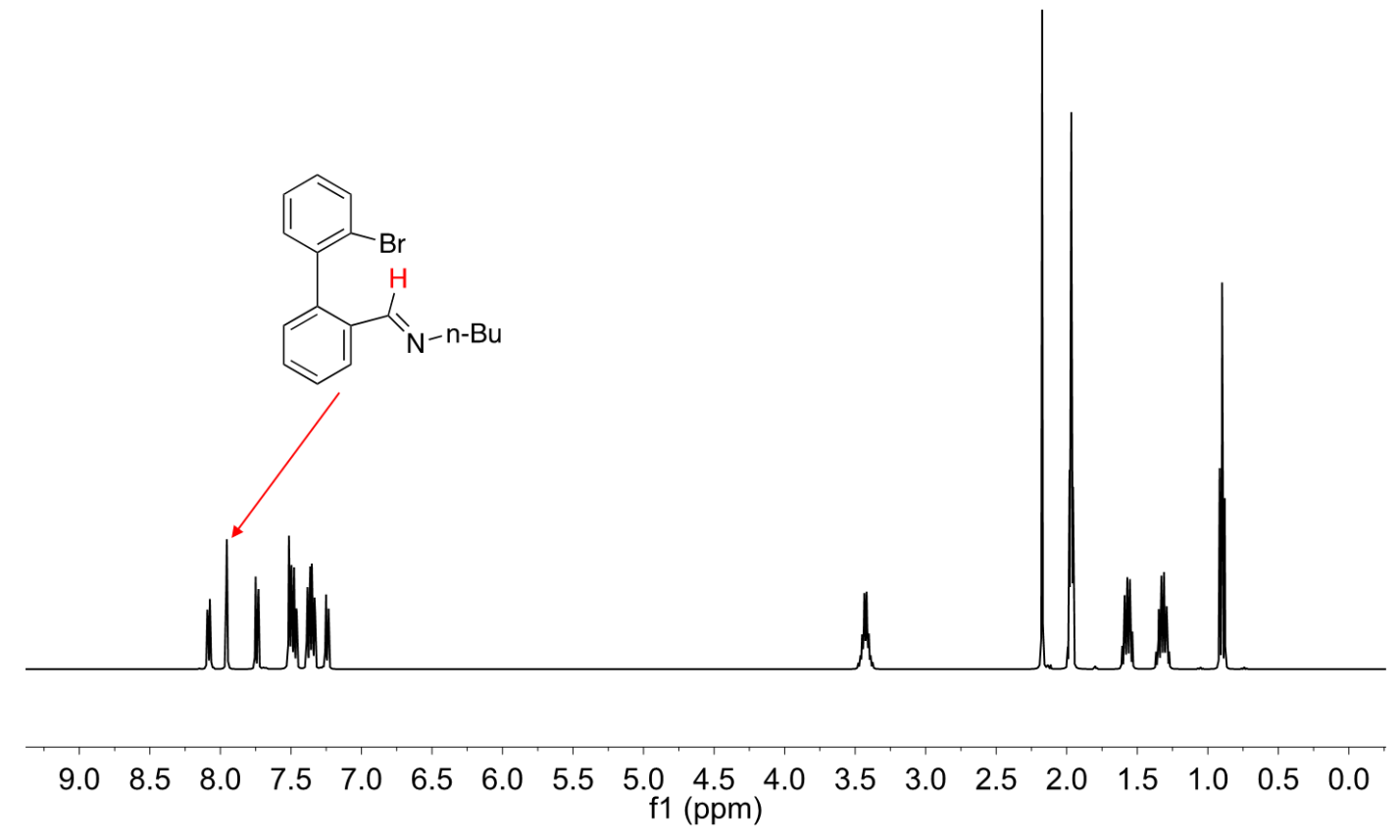

Figure S21. ${ }^{1} \mathrm{H}$ NMR spectrum of the reaction of $1(\mathrm{Br})$ and 1-butylamine in $\mathrm{CD}_{3} \mathrm{CN}$.

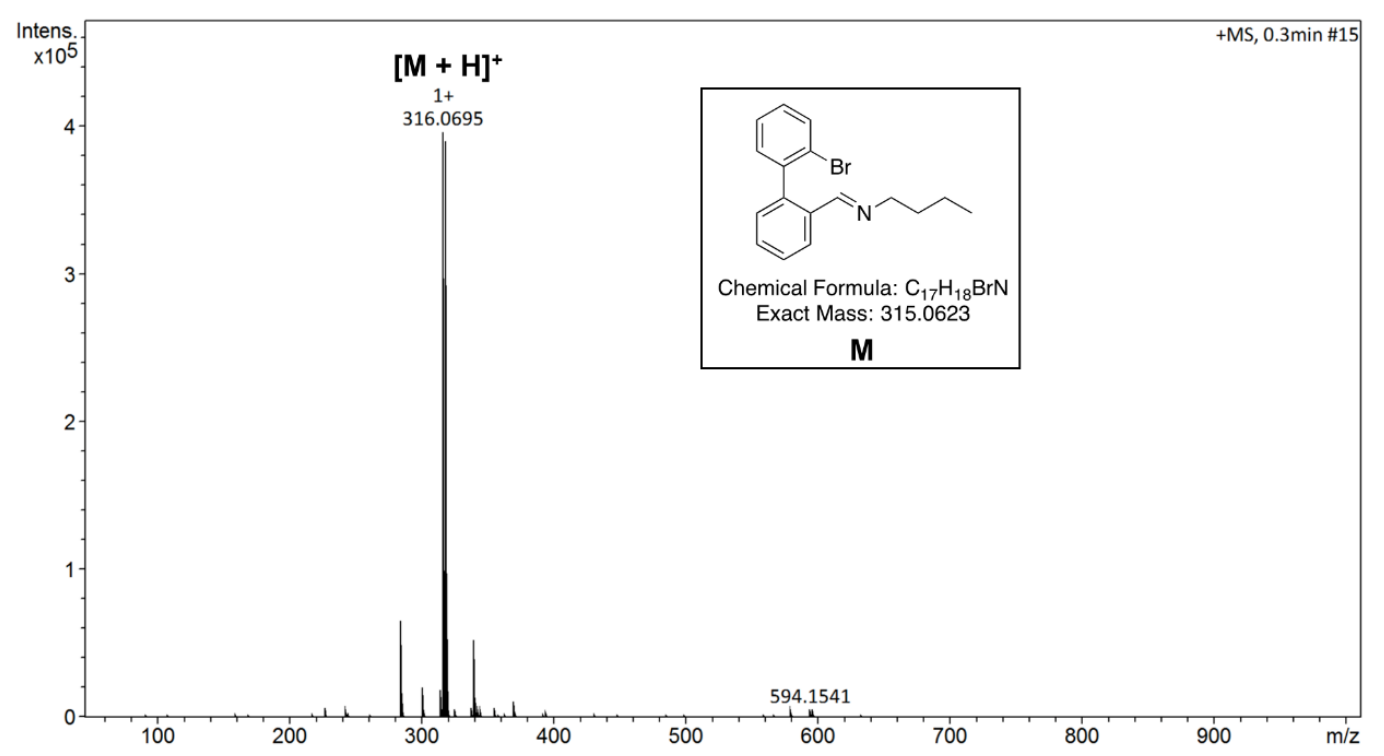

Figure S22. ESI-MS spectrum of the reaction of $\mathbf{1}(\mathrm{Br})$ and 1-butylamine in $\mathrm{CD}_{3} \mathrm{CN}$. 


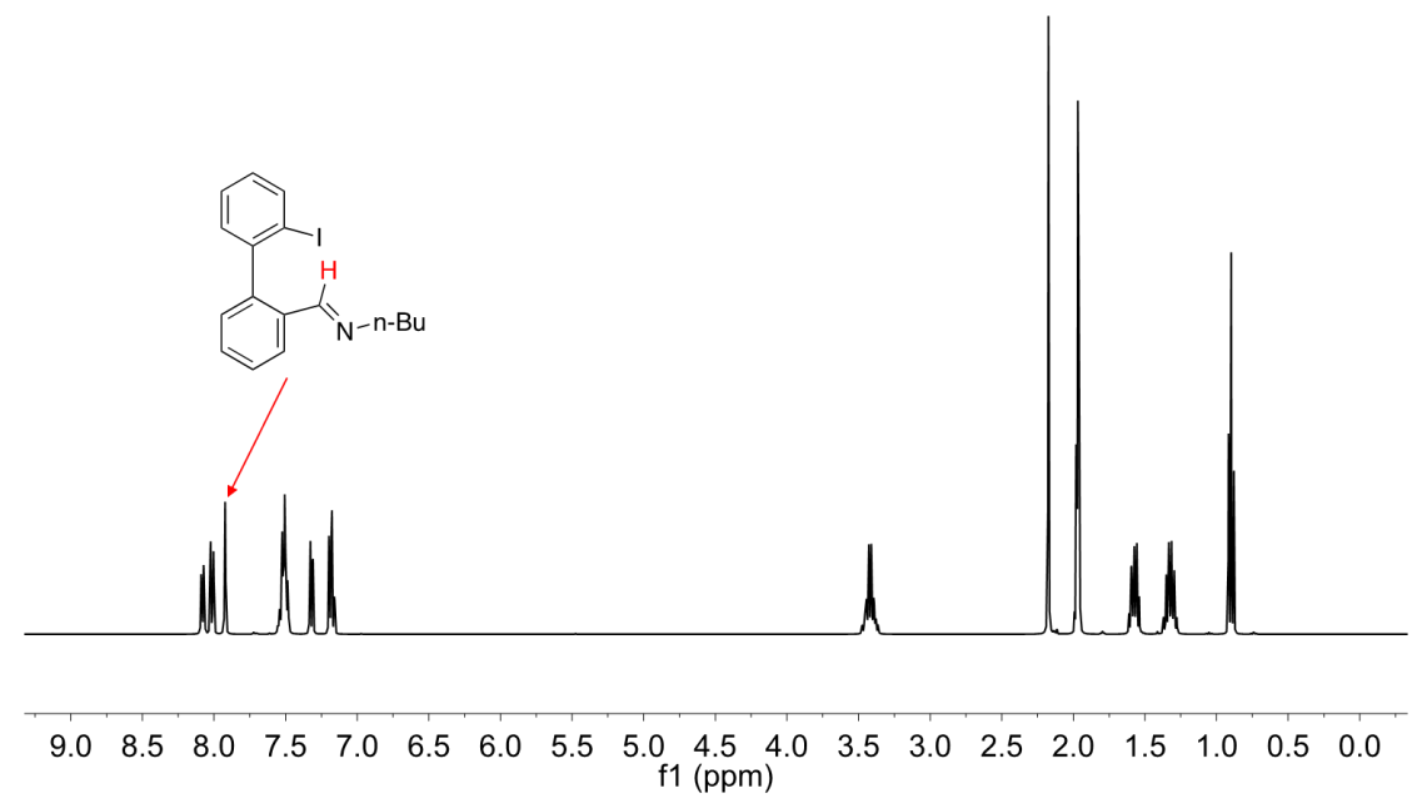

Figure S23. ${ }^{1} \mathrm{H}$ NMR spectrum of the reaction of $\mathbf{1}(\mathrm{I})$ and 1-butylamine in $\mathrm{CD}_{3} \mathrm{CN}$.

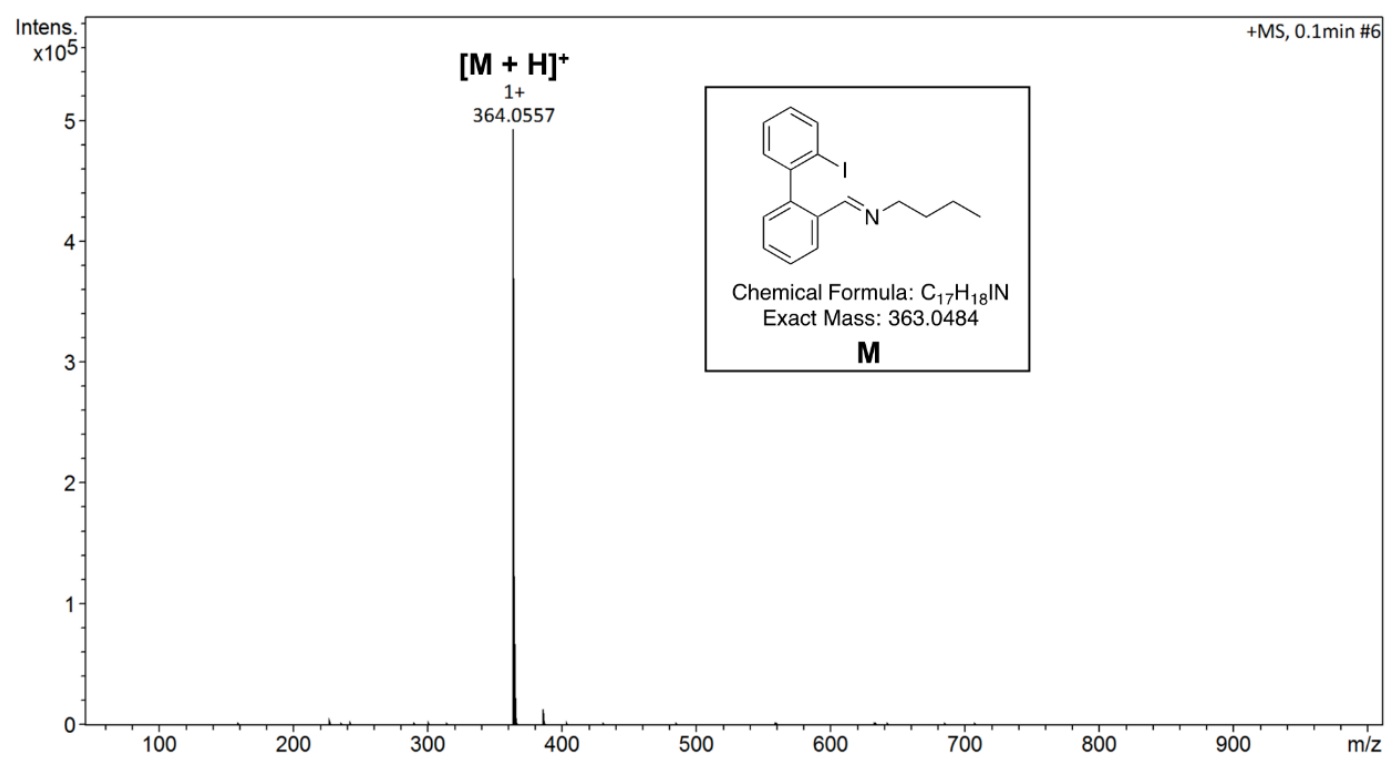

Figure S24. ESI-MS spectrum of the reaction of $1(\mathrm{I})$ and 1-butylamine in $\mathrm{CD}_{3} \mathrm{CN}$. 


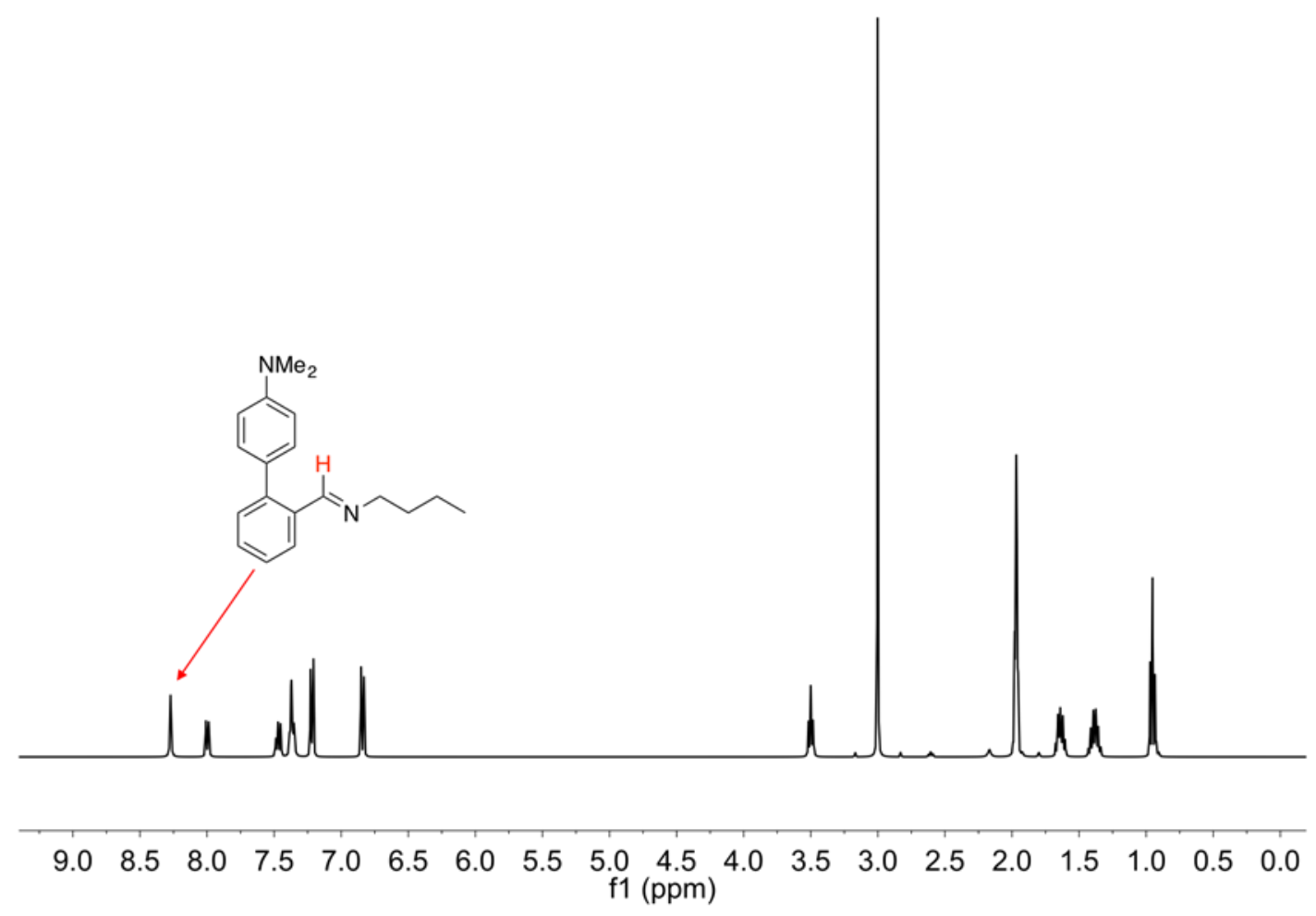

Figure S25. ${ }^{1} \mathrm{H}$ NMR spectrum of the reaction of $\mathbf{1}\left(p-\mathrm{NMe}_{2}\right)$ and 1-butylamine in $\mathrm{CD}_{3} \mathrm{CN}$.

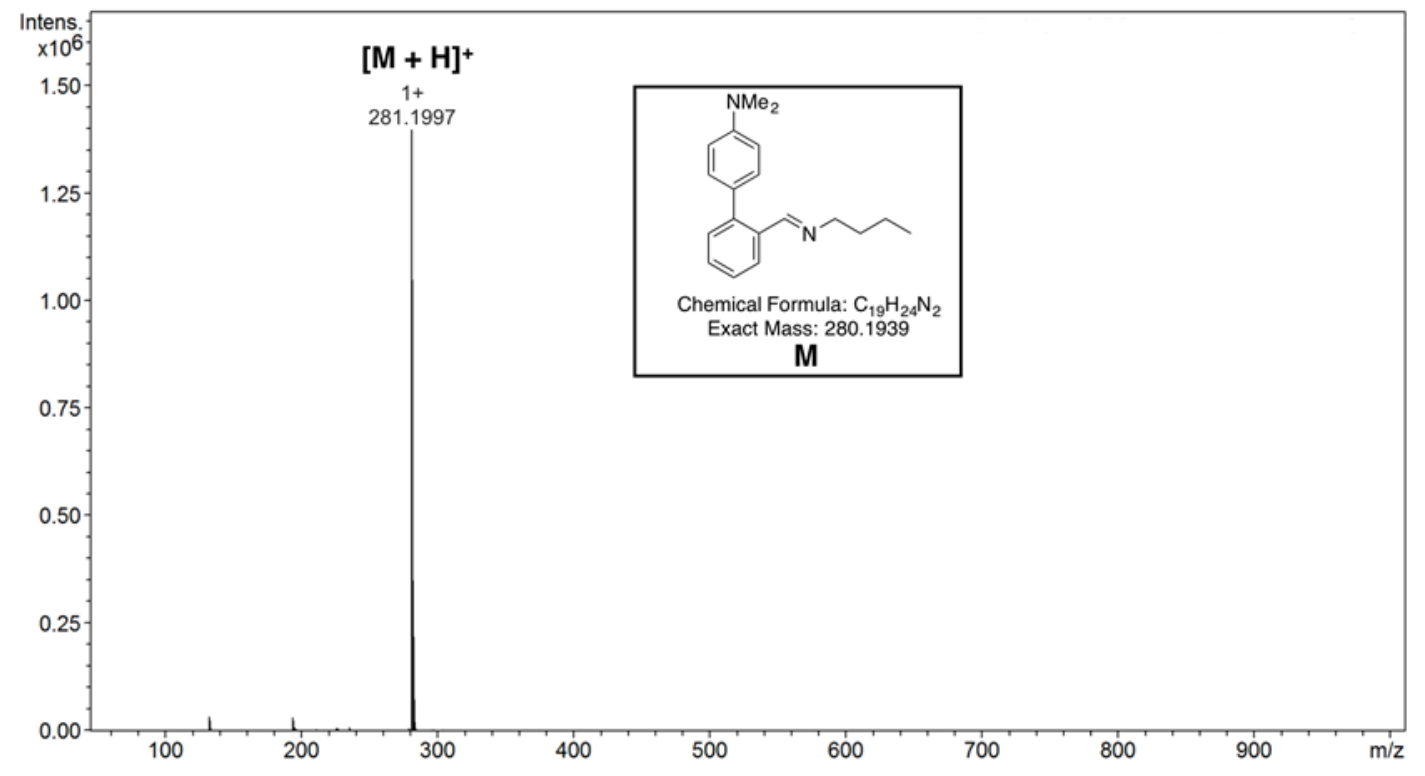

Figure S26. ESI-MS spectrum of the reaction of $\mathbf{1}\left(p-\mathrm{NMe}_{2}\right)$ and 1-butylamine in $\mathrm{CD}_{3} \mathrm{CN}$. 


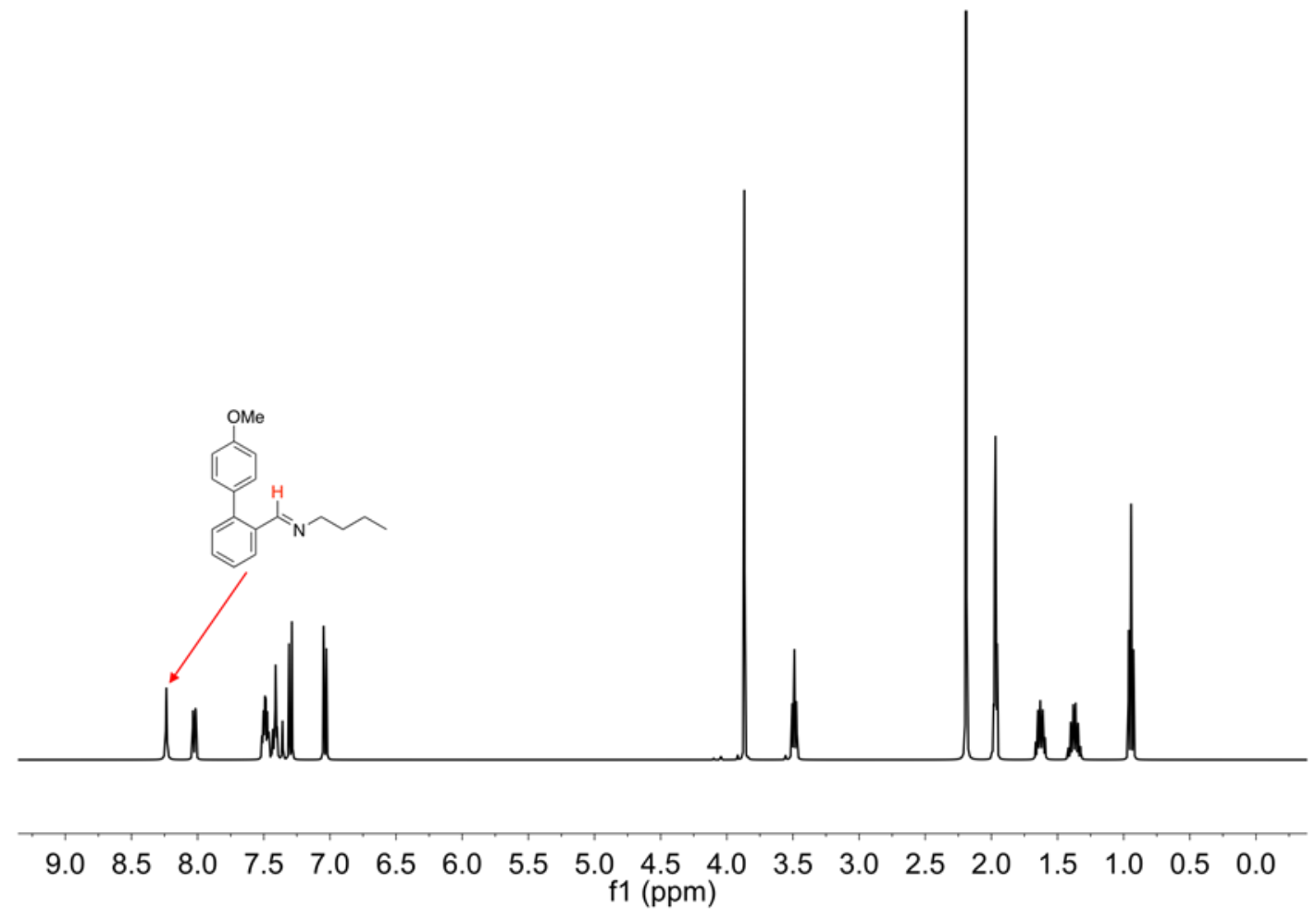

Figure S27. ${ }^{1} \mathrm{H}$ NMR spectrum of the reaction of $\mathbf{1}(p-\mathrm{OMe})$ and 1-butylamine in $\mathrm{CD}_{3} \mathrm{CN}$.

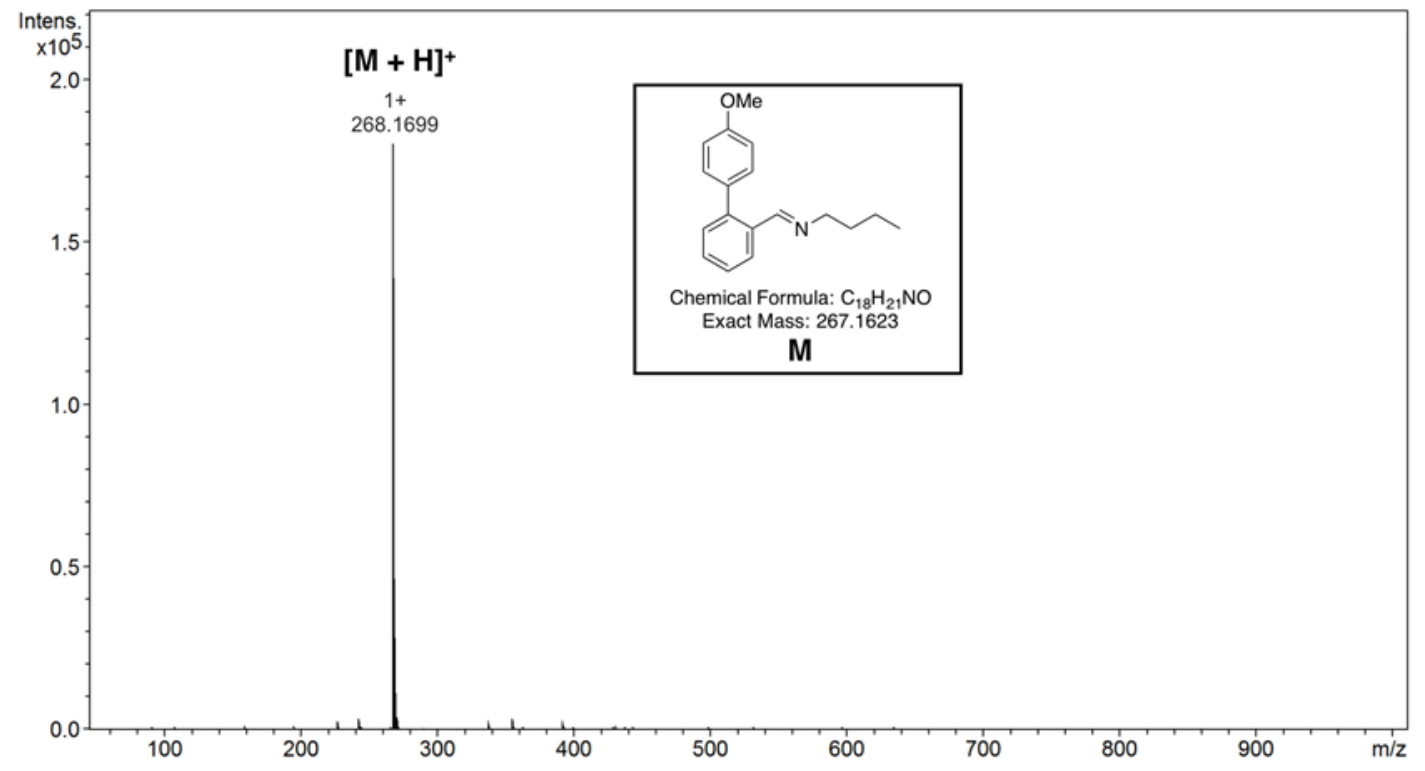

Figure S28. ESI-MS spectrum of the reaction of $1(p-\mathrm{OMe})$ and 1-butylamine in $\mathrm{CD}_{3} \mathrm{CN}$. 

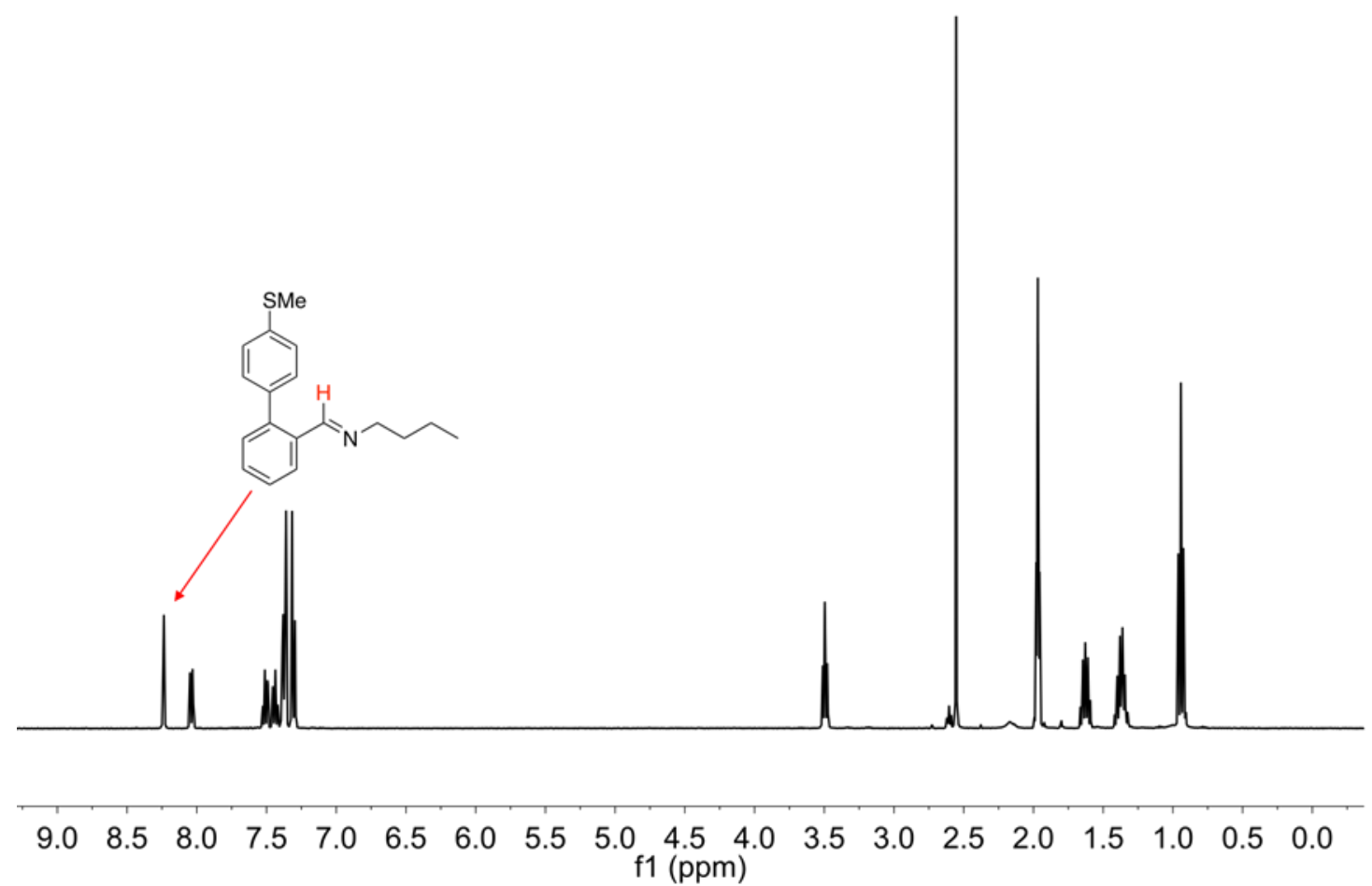

Figure S29. ${ }^{1} \mathrm{H}$ NMR spectrum of the reaction of $1(p-\mathrm{SMe})$ and 1-butylamine in $\mathrm{CD}_{3} \mathrm{CN}$.

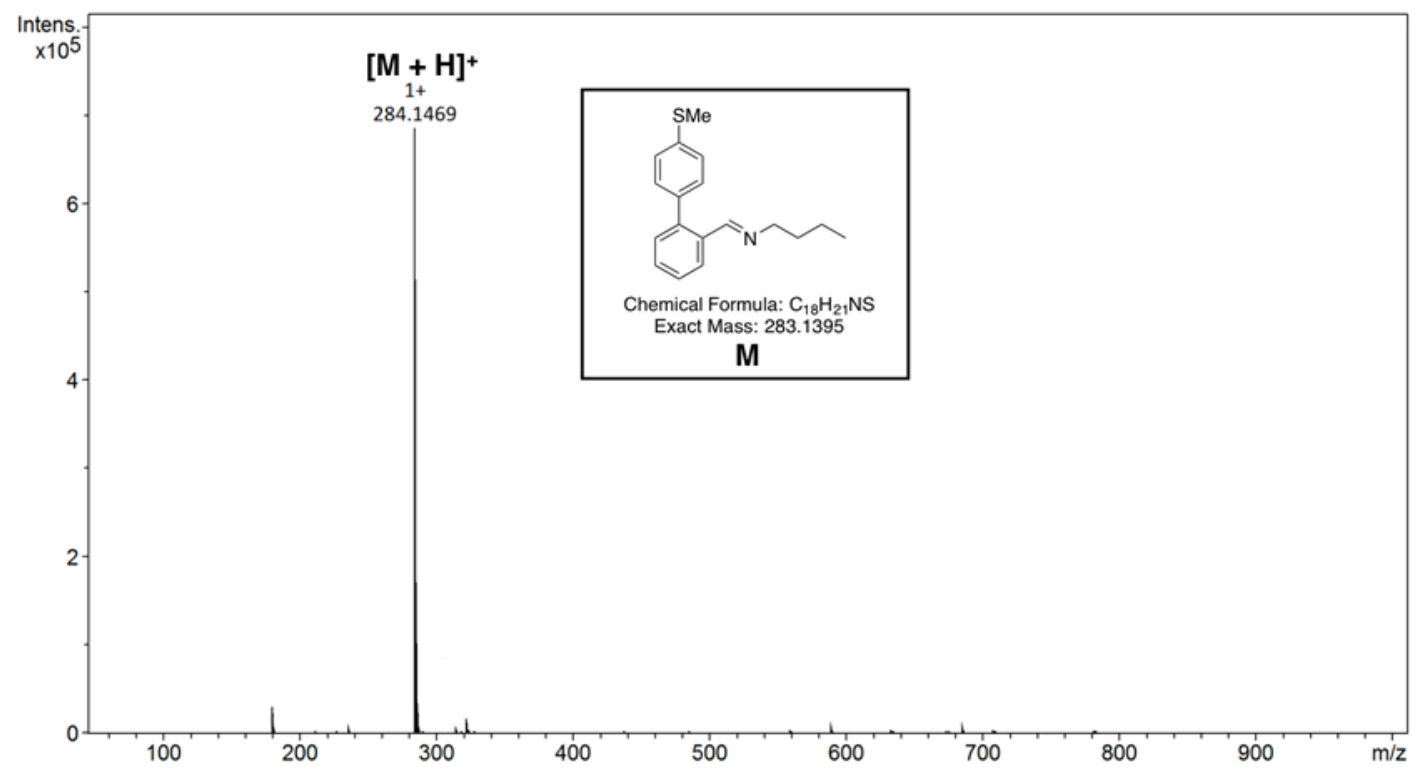

Figure S30. ESI-MS spectrum of the reaction of $1(p-\mathrm{SMe})$ and 1-butylamine in $\mathrm{CD}_{3} \mathrm{CN}$. 

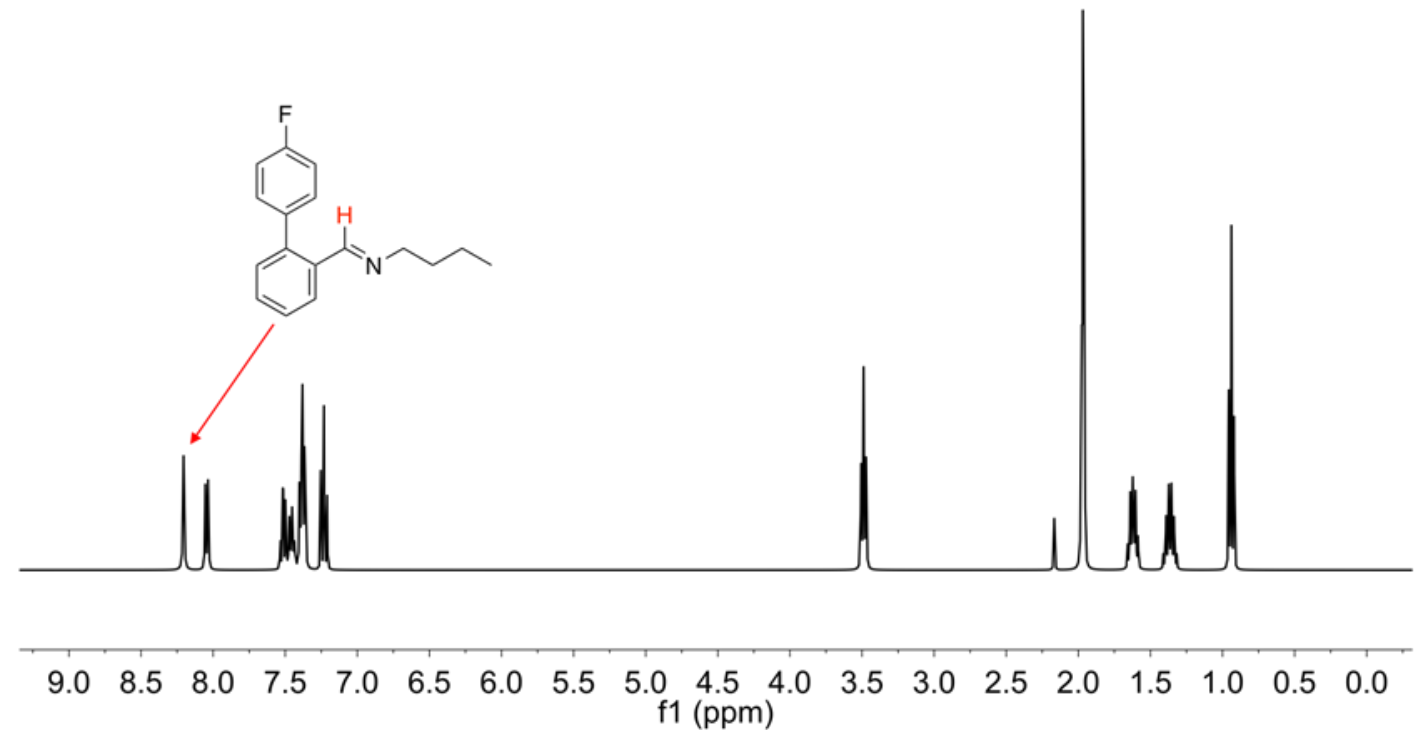

Figure S31. ${ }^{1} \mathrm{H}$ NMR spectrum of the reaction of $1(p-\mathrm{F})$ and 1-butylamine in $\mathrm{CD}_{3} \mathrm{CN}$.

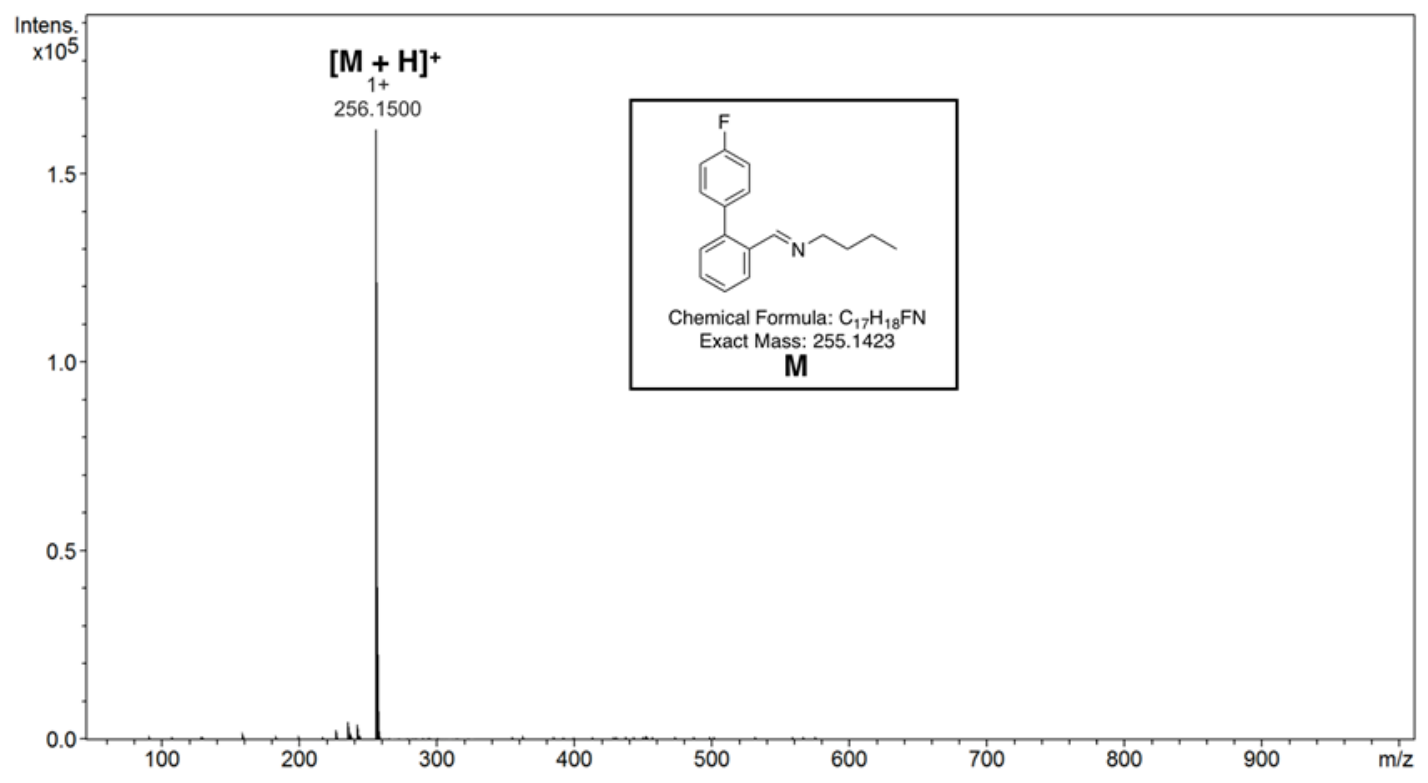

Figure S32. ESI-MS spectrum of the reaction of $1(p-\mathrm{F})$ and 1-butylamine in $\mathrm{CD}_{3} \mathrm{CN}$. 

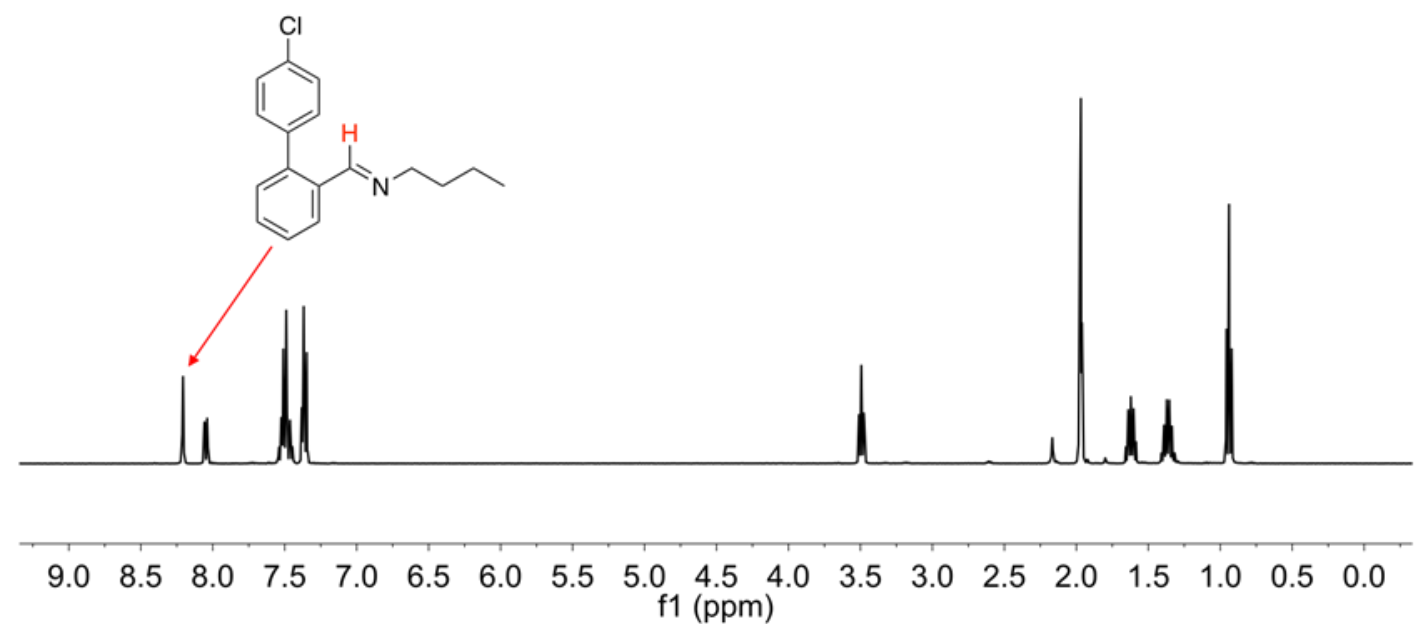

Figure S33. ${ }^{1} \mathrm{H}$ NMR spectrum of the reaction of $1(p-\mathrm{Cl})$ and 1-butylamine in $\mathrm{CD}_{3} \mathrm{CN}$.

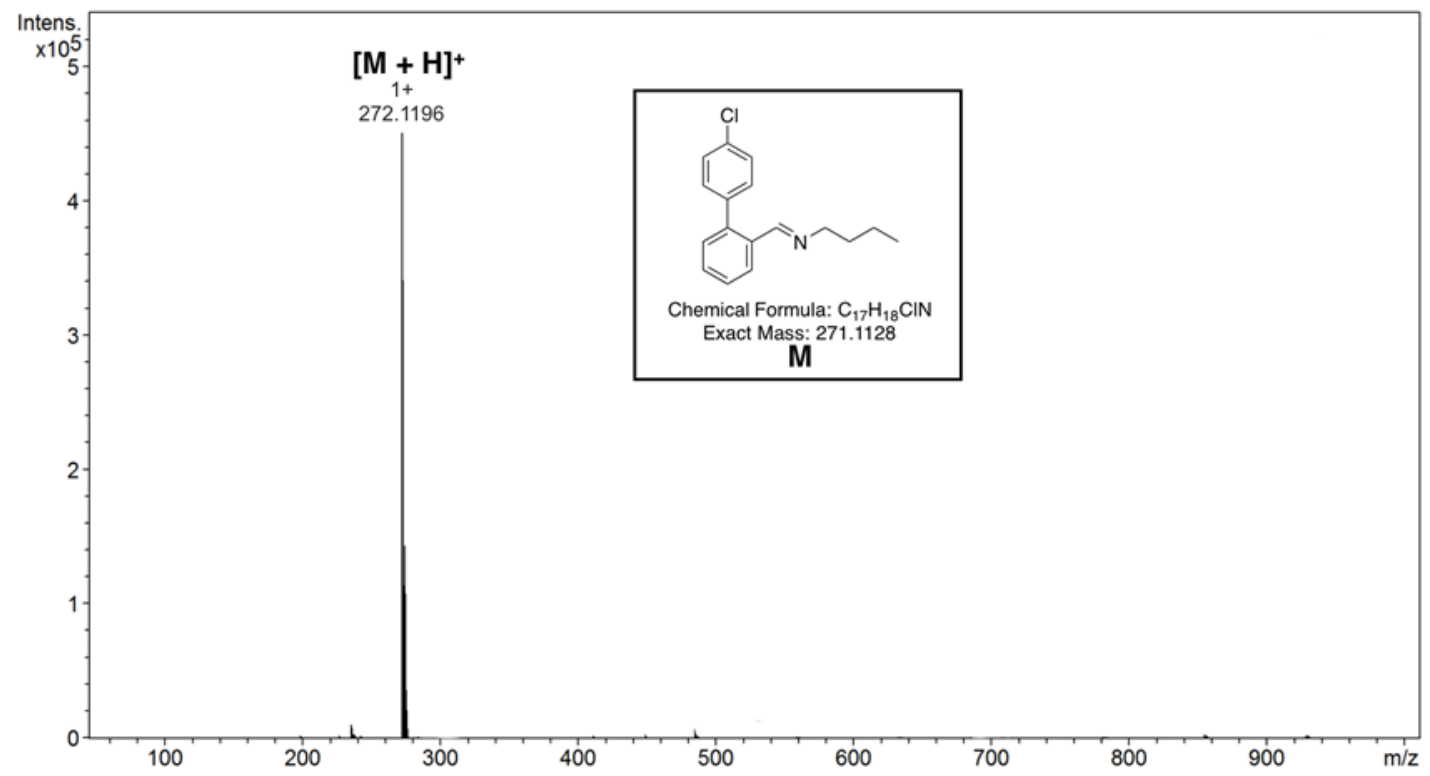

Figure S34. ESI-MS spectrum of the reaction of $1(p-C l)$ and 1-butylamine in $\mathrm{CD}_{3} \mathrm{CN}$. 

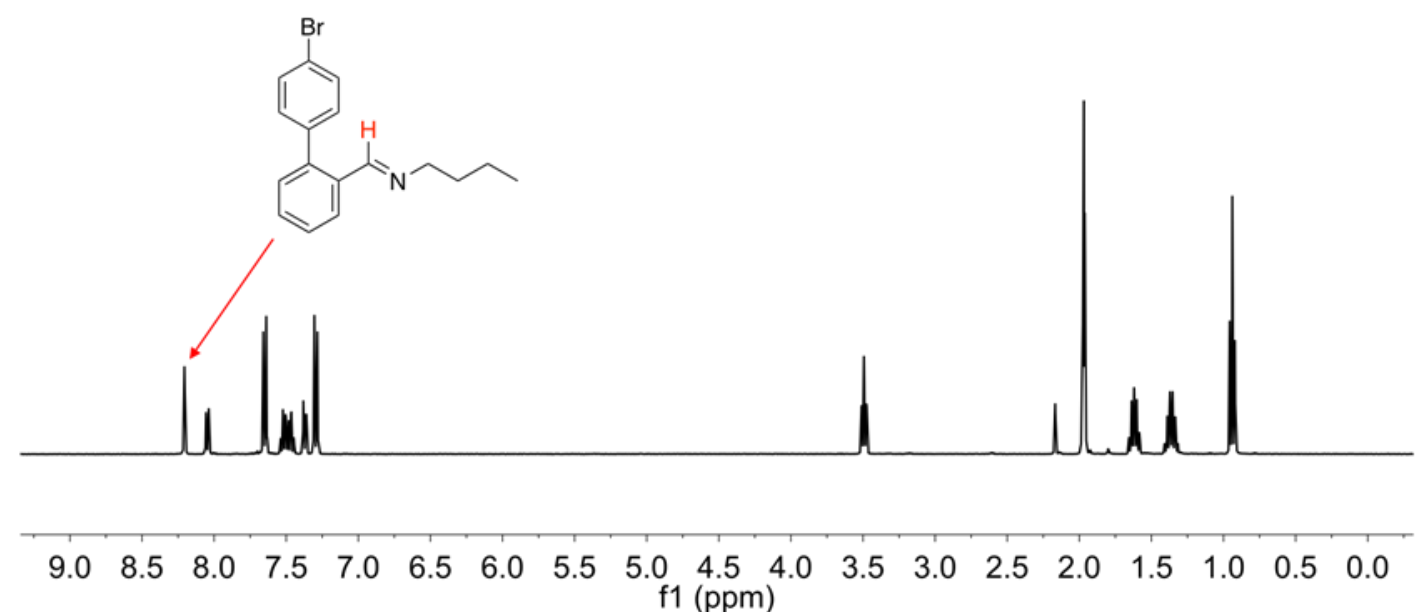

Figure S35. ${ }^{1} \mathrm{H}$ NMR spectrum of the reaction of $1(p-\mathrm{Br})$ and 1-butylamine in $\mathrm{CD}_{3} \mathrm{CN}$.

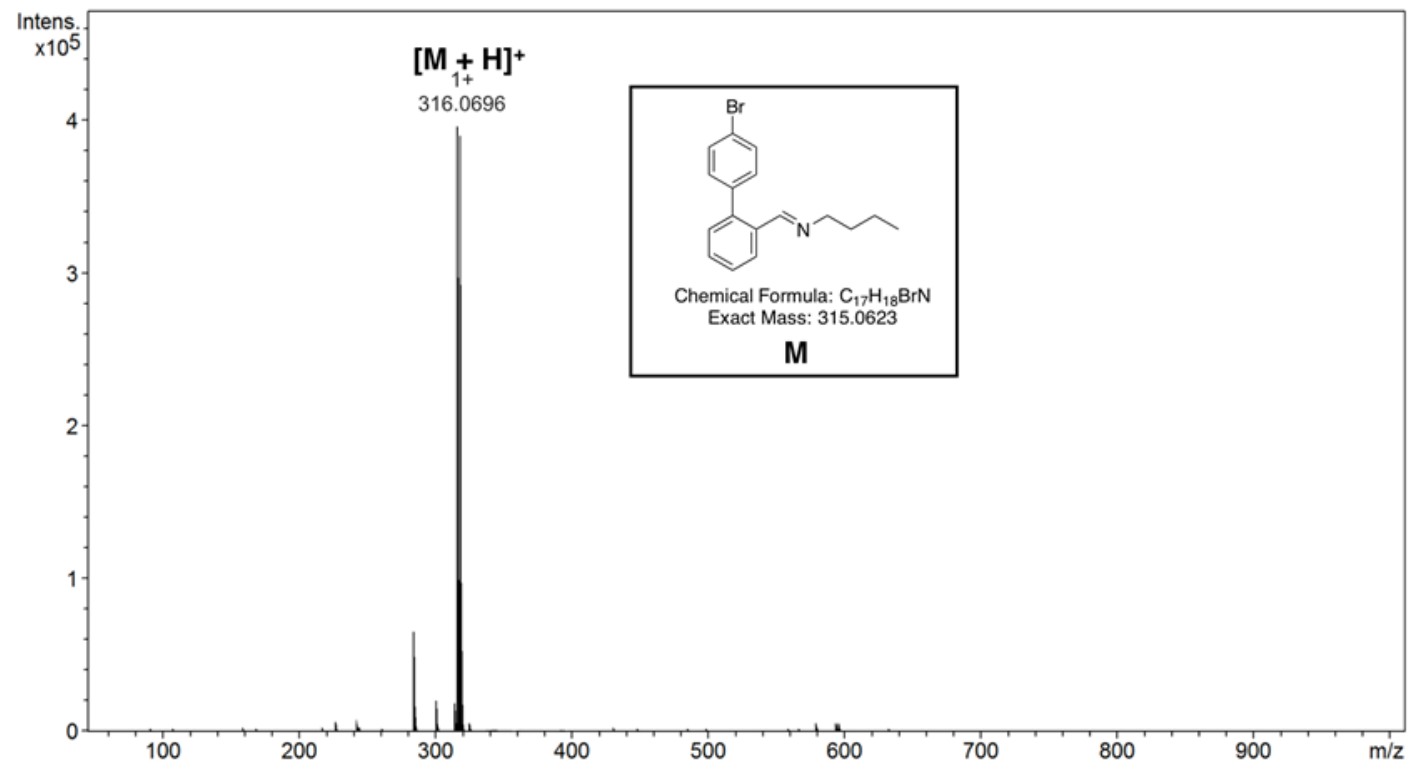

Figure S36. ESI-MS spectrum of the reaction of $1(p-\mathrm{Br})$ and 1-butylamine in $\mathrm{CD}_{3} \mathrm{CN}$. 


\section{(2) Imine exchange}

Table S2. The equilibrium constant and equilibrating time of the imine exchange with different sequence of reagents addition in different solvents.

\begin{tabular}{|c|c|c|c|c|}
\hline & $1(\mathrm{H})$ & & OMe) & $2(\mathrm{H})$ \\
\hline Panel & $\begin{array}{c}\text { Sequence of adding } \\
\text { reagents }\end{array}$ & Solvent & $K$ & Equilibrating time \\
\hline $\mathrm{a}$ & \multirow{3}{*}{$\begin{array}{c}\text { Generate } 2(\mathrm{OMe}) \text { in situ, } \\
\text { then add } \mathbf{1}(\mathrm{H})\end{array}$} & $\mathrm{CD}_{3} \mathrm{CN}$ & 1.63 & 180 day \\
\hline b & & $\begin{array}{c}5 \% \mathrm{D}_{2} \mathrm{O} \\
95 \% \mathrm{CD}_{3} \mathrm{CN}\end{array}$ & 1.53 & 100 day \\
\hline $\mathrm{c}$ & & $\begin{array}{c}10 \% \mathrm{D}_{2} \mathrm{O} \\
90 \% \mathrm{CD}_{3} \mathrm{CN}\end{array}$ & 1.44 & 55 day \\
\hline d & \multirow{3}{*}{$\begin{array}{l}\text { Generate } \mathbf{2}(\mathrm{H}) \text { in situ, } \\
\text { then add } \mathbf{1}(\mathrm{OMe})\end{array}$} & $\mathrm{CD}_{3} \mathrm{CN}$ & 1.64 & 150 day \\
\hline $\mathrm{e}$ & & $\begin{array}{c}5 \% \mathrm{D}_{2} \mathrm{O} \\
95 \% \mathrm{CD}_{3} \mathrm{CN}\end{array}$ & 1.54 & 58 day \\
\hline f & & $\begin{array}{c}10 \% \mathrm{D}_{2} \mathrm{O} \\
90 \% \mathrm{CD}_{3} \mathrm{CN}\end{array}$ & 1.44 & 30 day \\
\hline $\mathrm{g}$ & \multirow{3}{*}{$\begin{array}{c}\mathbf{1}(\mathrm{H}) \text { and } \mathbf{1}(\mathrm{OMe}) \\
\text { simultaneously reacted } \\
\text { with 1-butylamine }\end{array}$} & $\mathrm{CD}_{3} \mathrm{CN}$ & 1.64 & 1 day \\
\hline $\mathrm{h}$ & & $\begin{array}{c}5 \% \mathrm{D}_{2} \mathrm{O} \\
95 \% \mathrm{CD}_{3} \mathrm{CN}\end{array}$ & 1.52 & 1 day \\
\hline $\mathrm{i}$ & & $\begin{array}{c}10 \% \mathrm{D}_{2} \mathrm{O} \\
90 \% \mathrm{CD}_{3} \mathrm{CN}\end{array}$ & 1.45 & 1 day \\
\hline
\end{tabular}




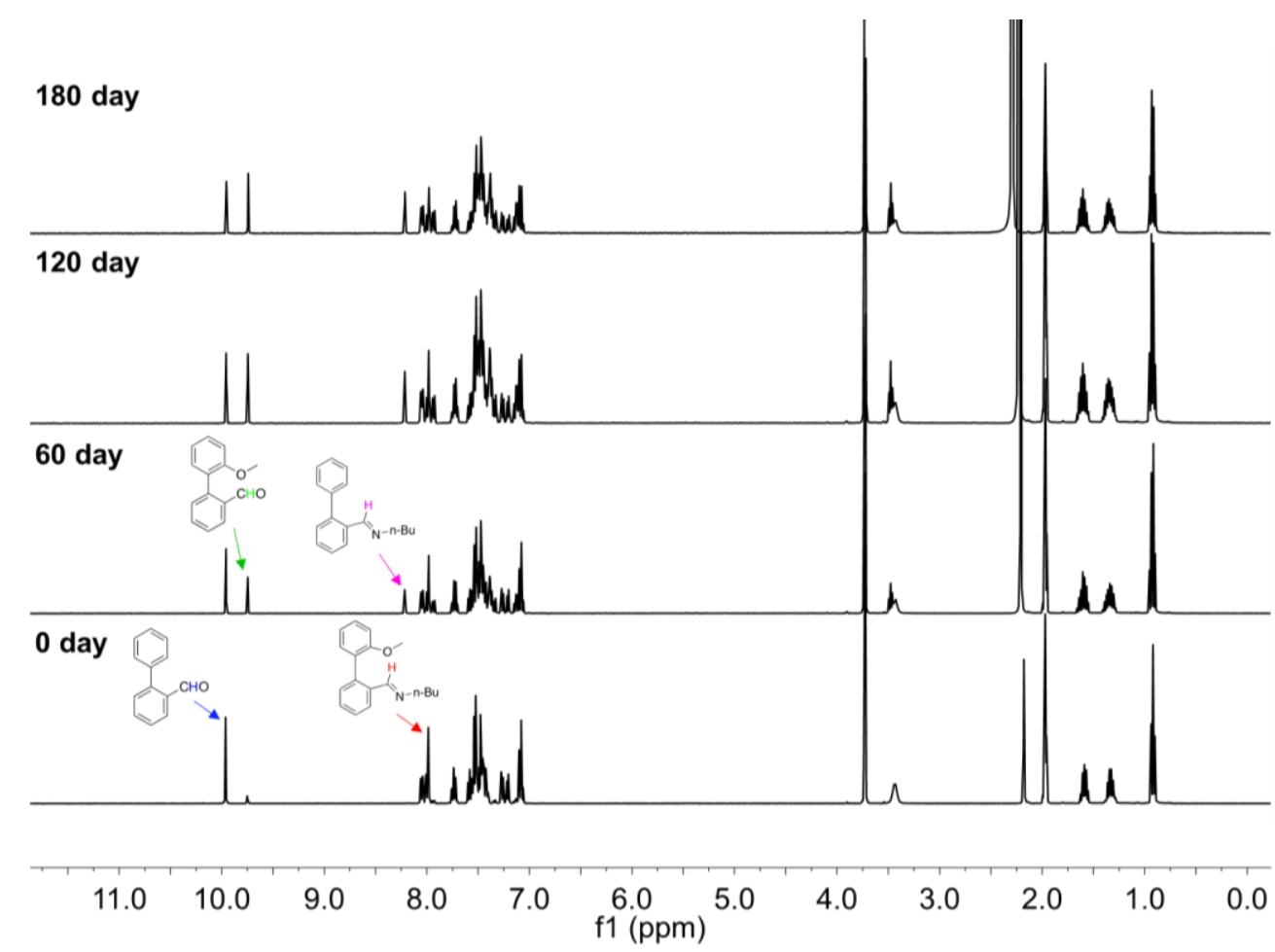

Figure S37. ${ }^{1} \mathrm{H}$ NMR spectra of the reaction of preformed $2(\mathrm{OMe})$ and $\mathbf{1}(\mathrm{H})$ in $\mathrm{CD}_{3} \mathrm{CN}$ at varied time (the corresponding spectra of panel a in Table S2).

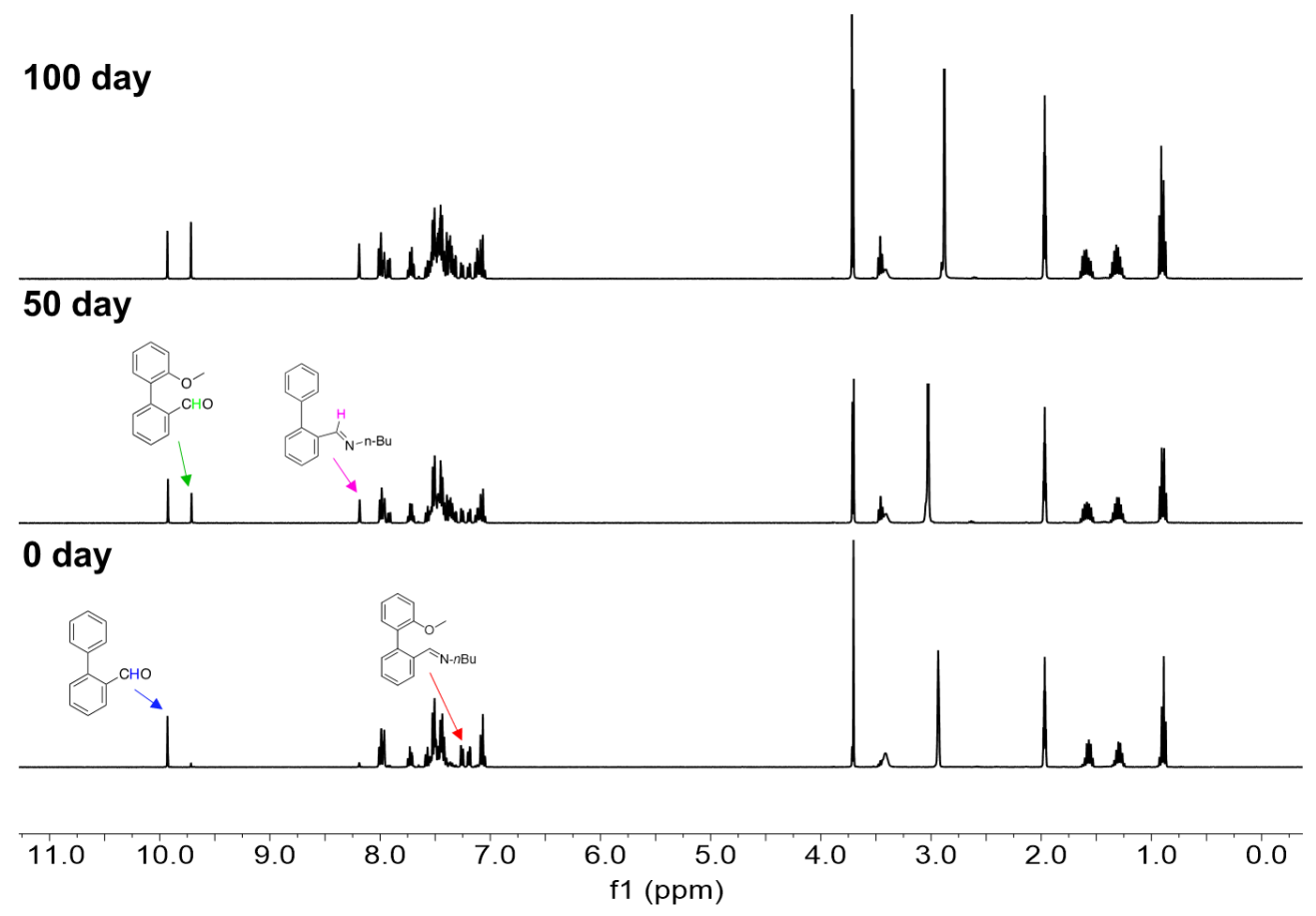

Figure S38. ${ }^{1} \mathrm{H}$ NMR spectra of the reaction of preformed $\mathbf{2}(\mathrm{OMe})$ and $\mathbf{1}(\mathrm{H})$ in mixed solvent $\left(5 \% \mathrm{D}_{2} \mathrm{O}, 95 \% \mathrm{CD}_{3} \mathrm{CN}\right)$ at varied time (the corresponding spectra of panel $\mathrm{b}$ in Table S2). 


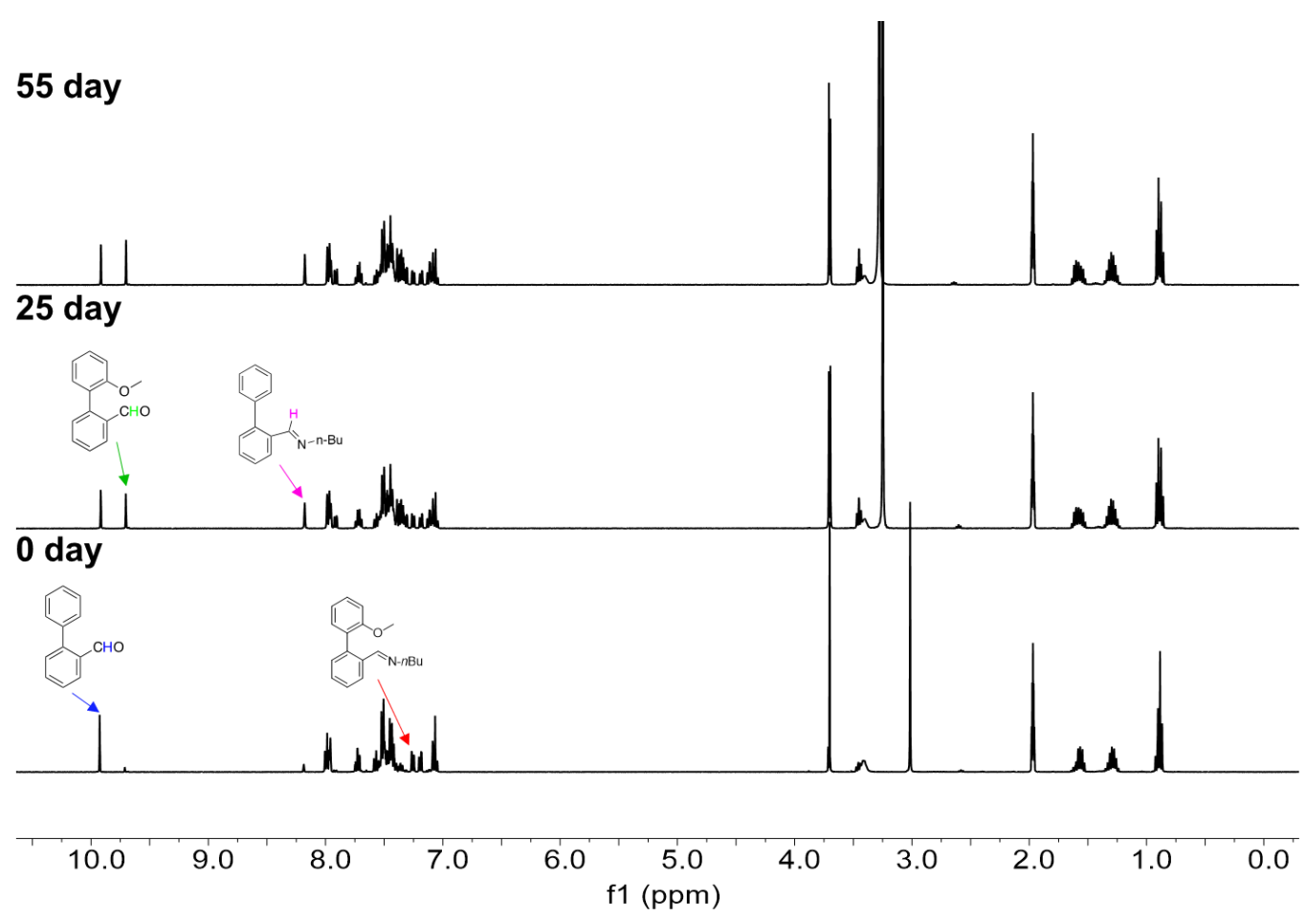

Figure S39. ${ }^{1} \mathrm{H}$ NMR spectra of the reaction of preformed $2(\mathrm{OMe})$ and $\mathbf{1}(\mathrm{H})$ in mixed solvent $\left(10 \% \mathrm{D}_{2} \mathrm{O}, 90 \% \mathrm{CD}_{3} \mathrm{CN}\right)$ at varied time (the corresponding spectra of panel c in Table S2).

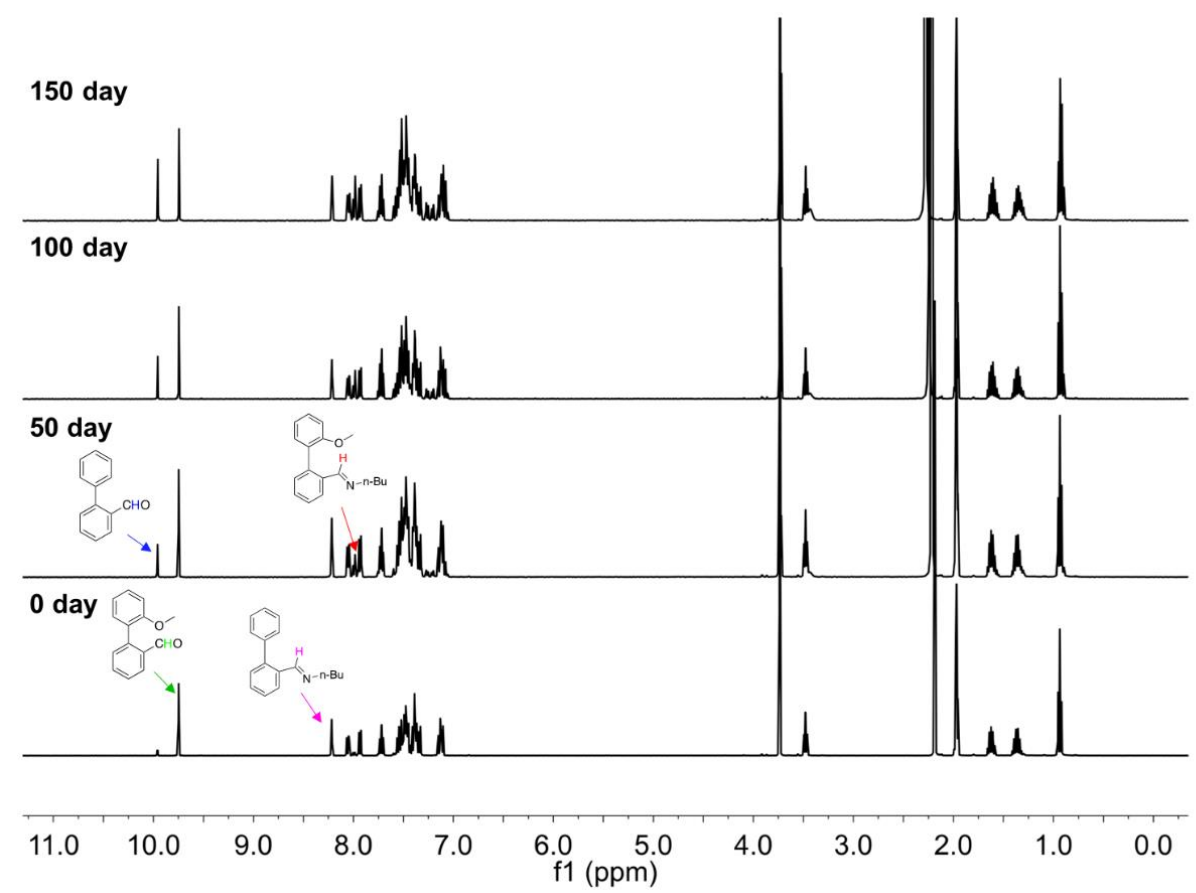

Figure S40. ${ }^{1} \mathrm{H}$ NMR spectra of the reaction of preformed $2(\mathrm{H})$ and $\mathbf{1}(\mathrm{OMe})$ in $\mathrm{CD}_{3} \mathrm{CN}$ at varied time (the corresponding spectra of panel $\mathrm{d}$ in Table S2). 


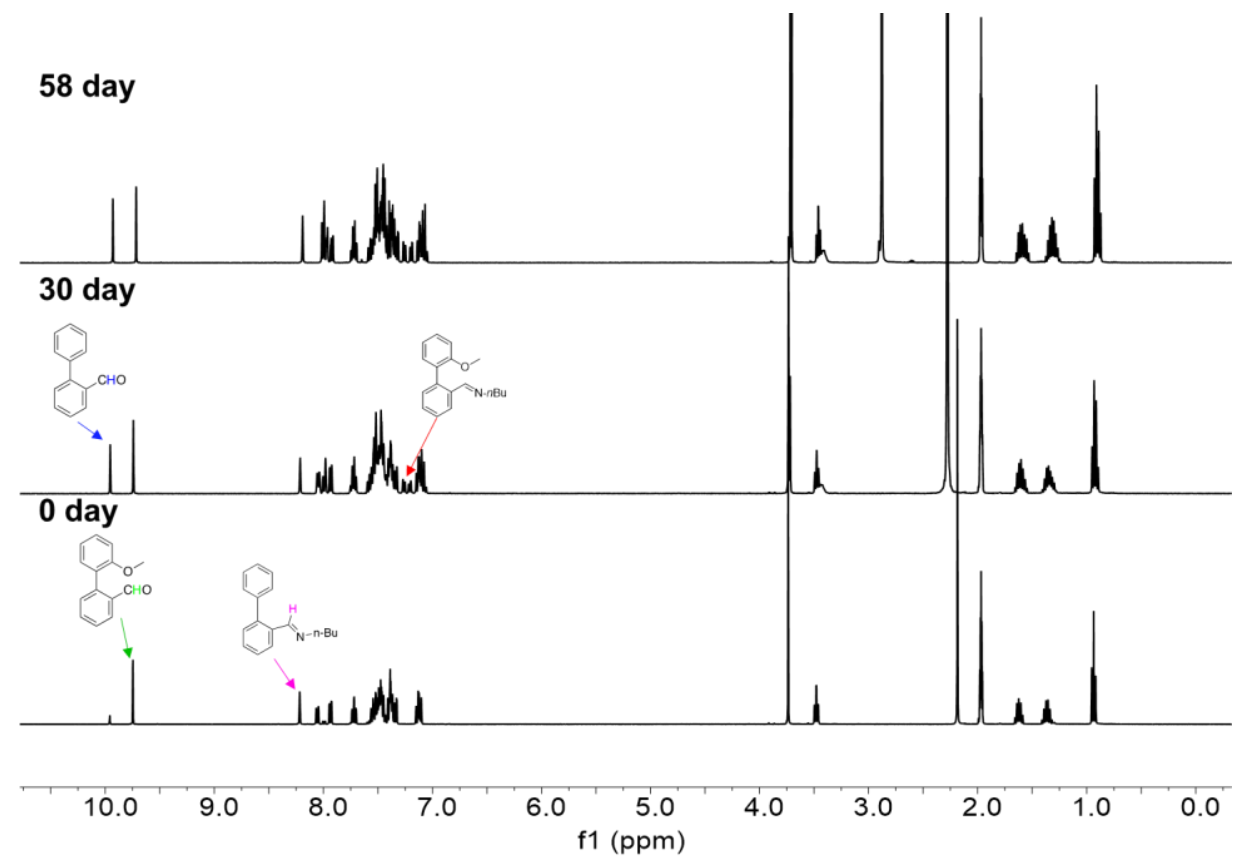

Figure S41. ${ }^{1} \mathrm{H}$ NMR spectra of the reaction of preformed $\mathbf{2}(\mathrm{H})$ and $\mathbf{1}(\mathrm{OMe})$ in mixed solvent $\left(5 \% \mathrm{D}_{2} \mathrm{O}, 95 \% \mathrm{CD}_{3} \mathrm{CN}\right)$ at varied time (the corresponding spectra of panel $\mathrm{e}$ in Table S2).

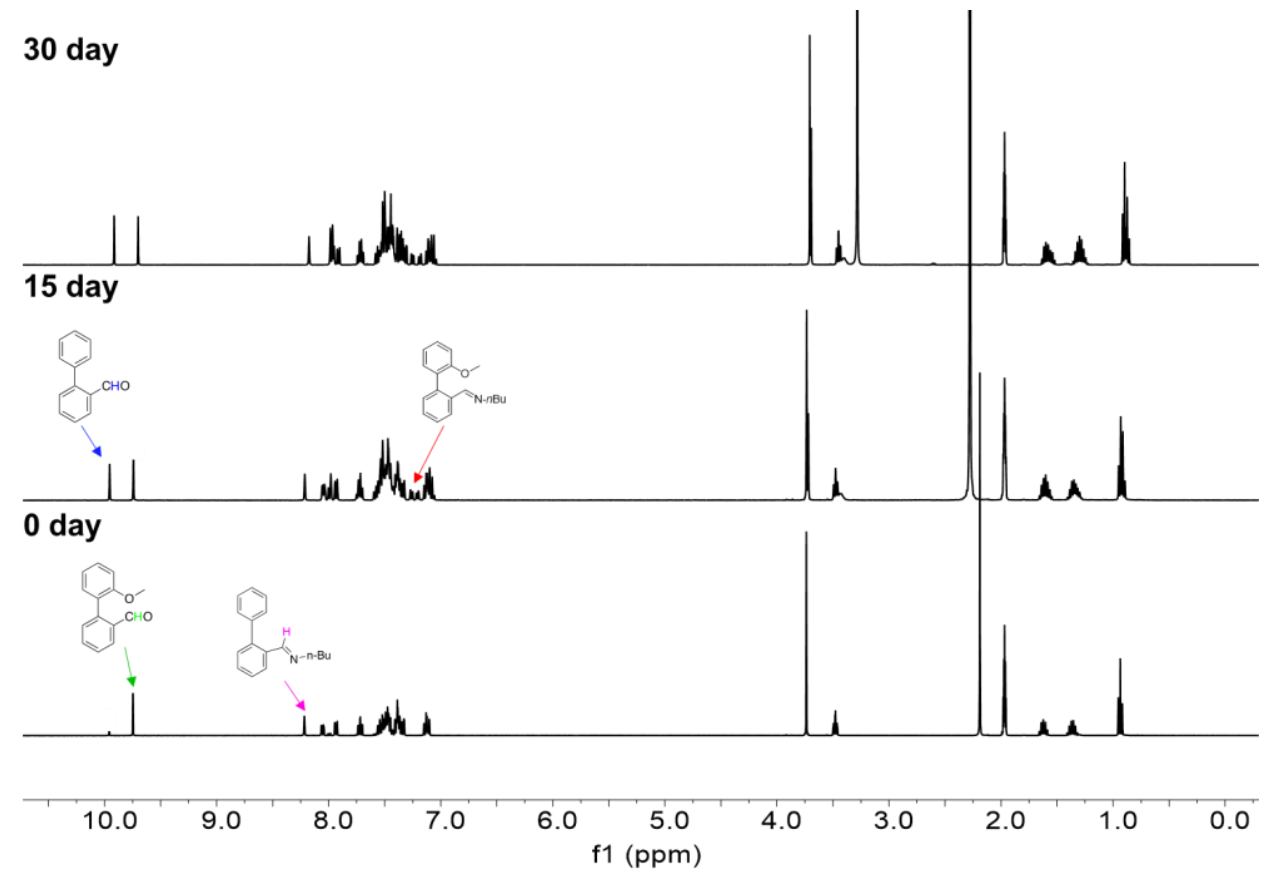

Figure S42. ${ }^{1} \mathrm{H}$ NMR spectra of the reaction of preformed $\mathbf{2}(\mathrm{H})$ and $\mathbf{1}(\mathrm{OMe})$ in mixed solvent $\left(10 \% \mathrm{D}_{2} \mathrm{O}, 90 \% \mathrm{CD}_{3} \mathrm{CN}\right)$ at varied time (the corresponding spectra of panel $\mathrm{f}$ in Table S2). 


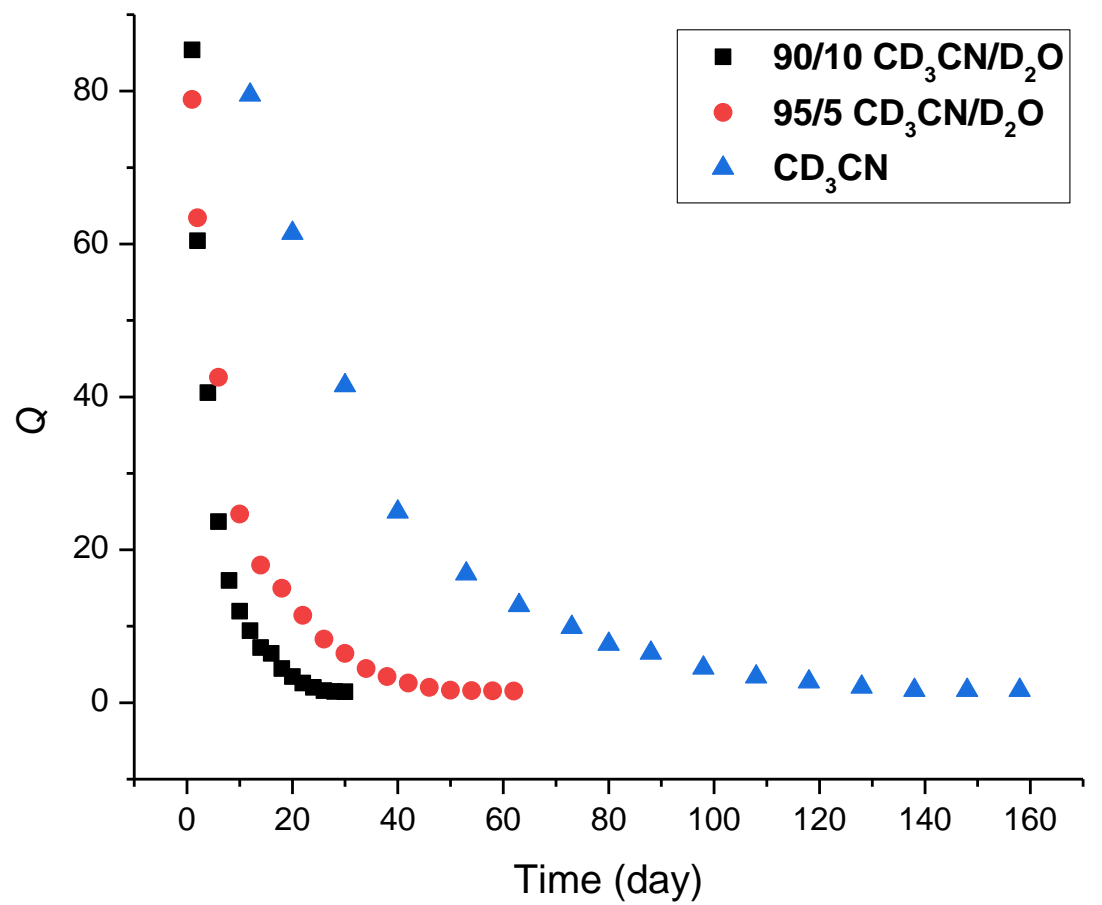

Figure S43. Kinetic profile of the reaction of preformed $2(\mathrm{H})$ and $\mathbf{1}(\mathrm{OMe})$ in different solvent.

Table S3. The equilibrium constants of imine exchange reactions. The representative NMR spectrums were shown in Figures S44-S56.

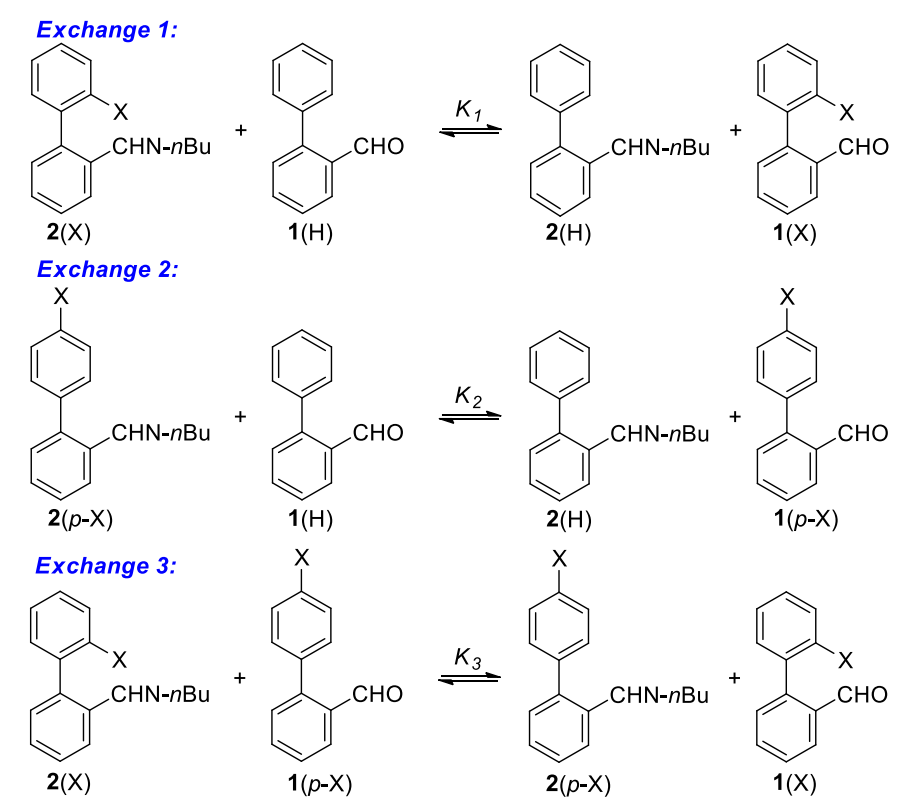

$\mathrm{X}=\mathrm{NMe}_{2}, \mathrm{OMe}, \mathrm{SMe}, \mathrm{F}, \mathrm{Cl}, \mathrm{Br}$, I

\begin{tabular}{cccc}
\hline $\mathbf{X}$ & $\boldsymbol{K}_{\boldsymbol{1}}$ & $\boldsymbol{K}_{\boldsymbol{2}}$ & $\boldsymbol{K}_{\mathbf{3}}$ \\
\hline $\mathrm{NMe}_{2}$ & 2.42 & 0.98 & 2.38
\end{tabular}




\begin{tabular}{cccc} 
OMe & 1.64 & 1.04 & 1.58 \\
$\mathrm{SMe}$ & 1.39 & 1.04 & 1.33 \\
$\mathrm{~F}$ & 1.19 & 1.03 & 1.13 \\
$\mathrm{Cl}$ & 1.06 & 1.01 & 1.08 \\
$\mathrm{Br}$ & 1.04 & 0.99 & 1.06 \\
$\mathrm{I}$ & 1.02 & - & - \\
$\mathrm{H}$ & 1 & 1 & 1 \\
\hline
\end{tabular}

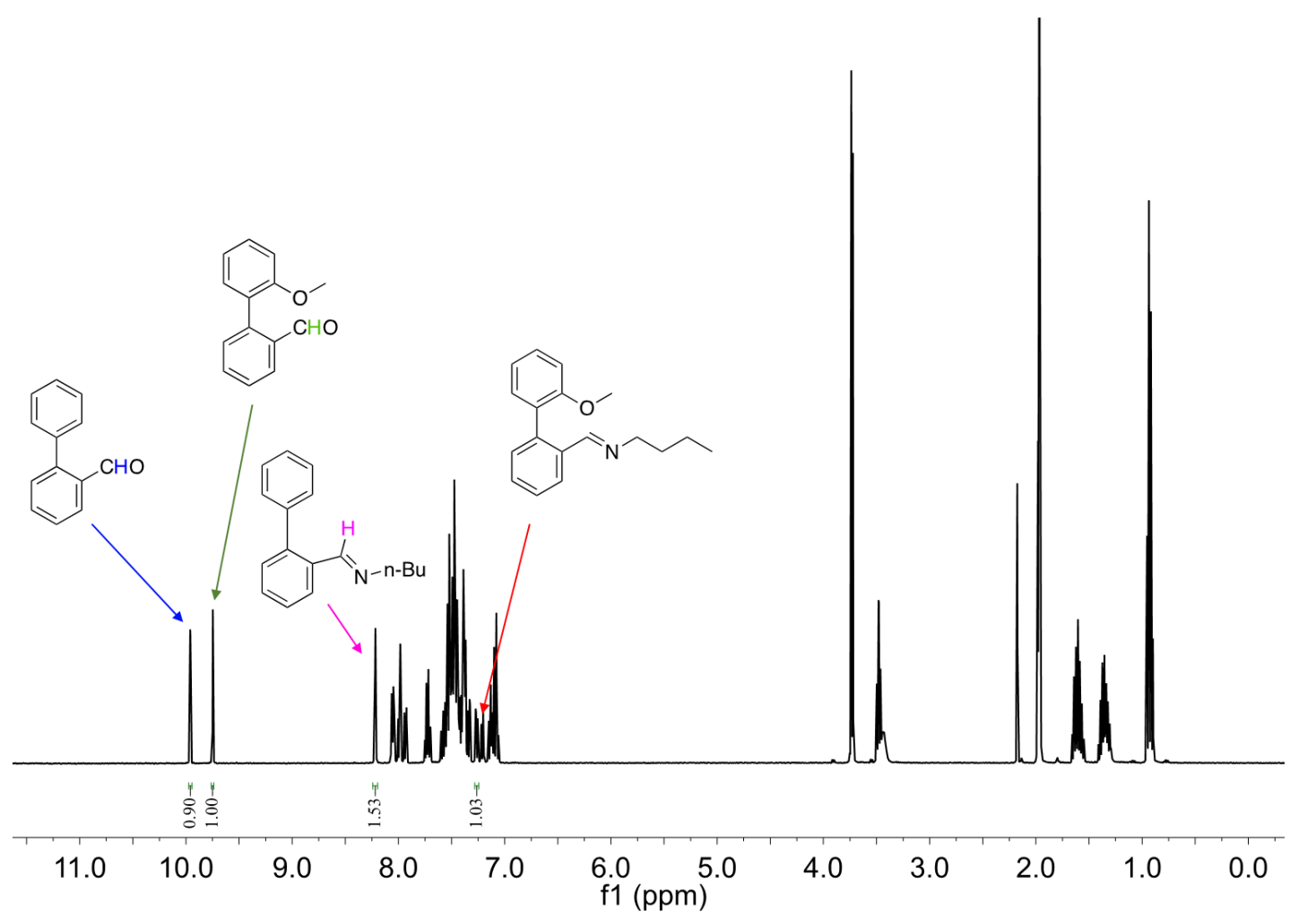

Figure S44. ${ }^{1} \mathrm{H}$ NMR spectrum of the competition between $\mathbf{1}(\mathrm{H})$ and $\mathbf{1}(\mathrm{OMe})$ for the reaction with 1-butylamine in $\mathrm{CD}_{3} \mathrm{CN}$. 


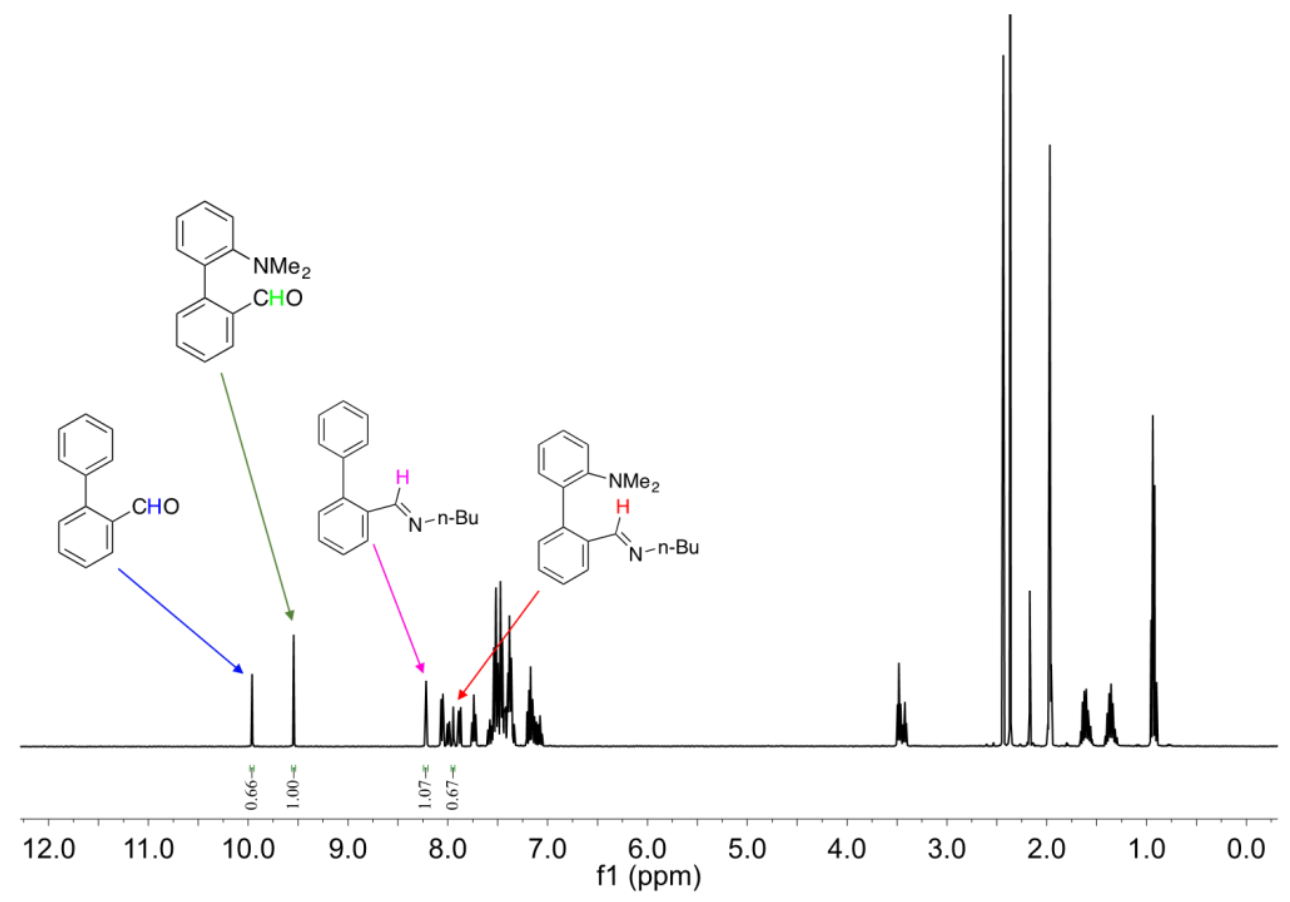

Figure S45. ${ }^{1} \mathrm{H}$ NMR spectrum of the competition between $\mathbf{1}(\mathrm{H})$ and $\mathbf{1}\left(\mathrm{NMe}_{2}\right)$ for the reaction with 1-butylamine in $\mathrm{CD}_{3} \mathrm{CN}$.

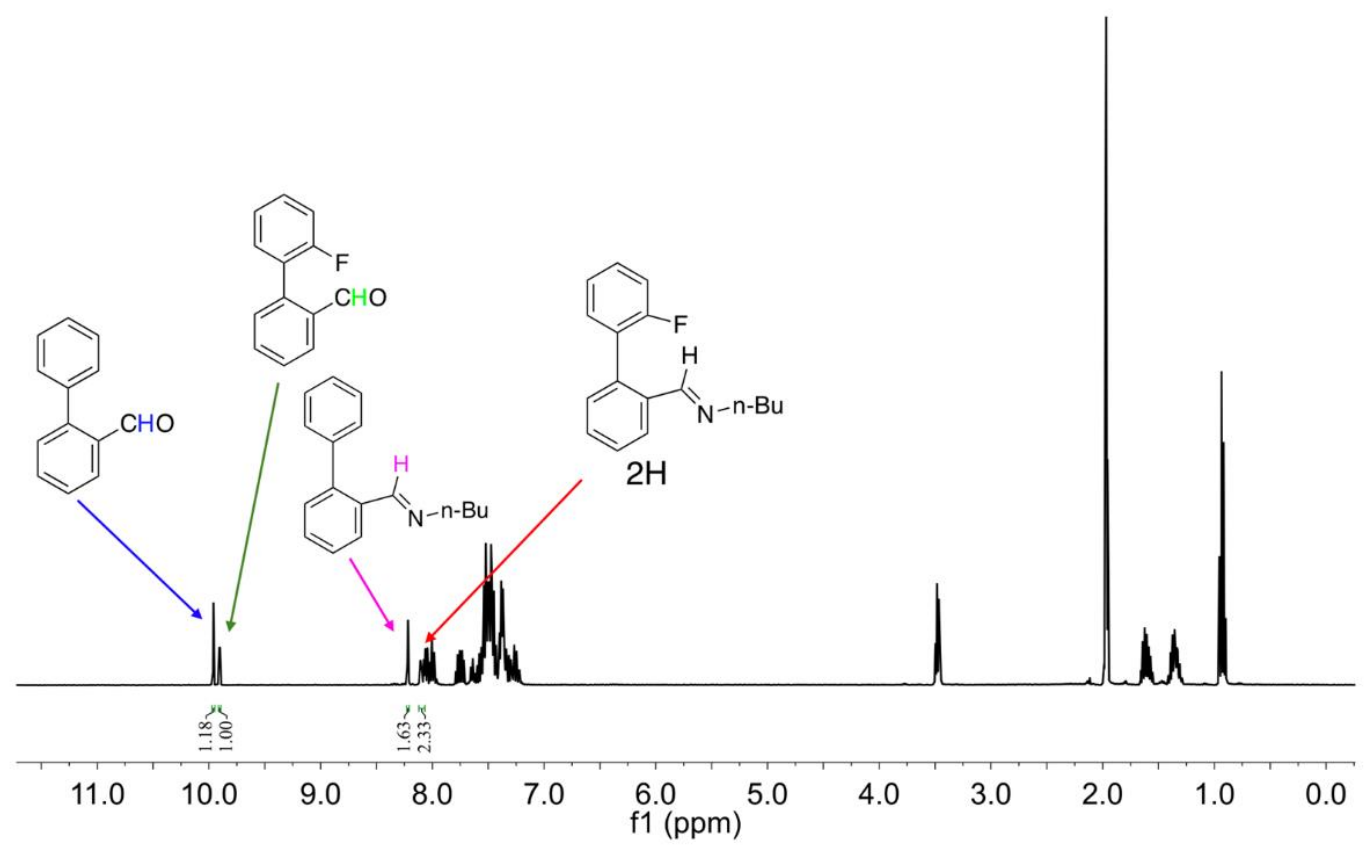

Figure S46. ${ }^{1} \mathrm{H}$ NMR spectrum of the competition between $1(\mathrm{H})$ and $\mathbf{1}(\mathrm{F})$ for the reaction with 1-butylamine in $\mathrm{CD}_{3} \mathrm{CN}$. 


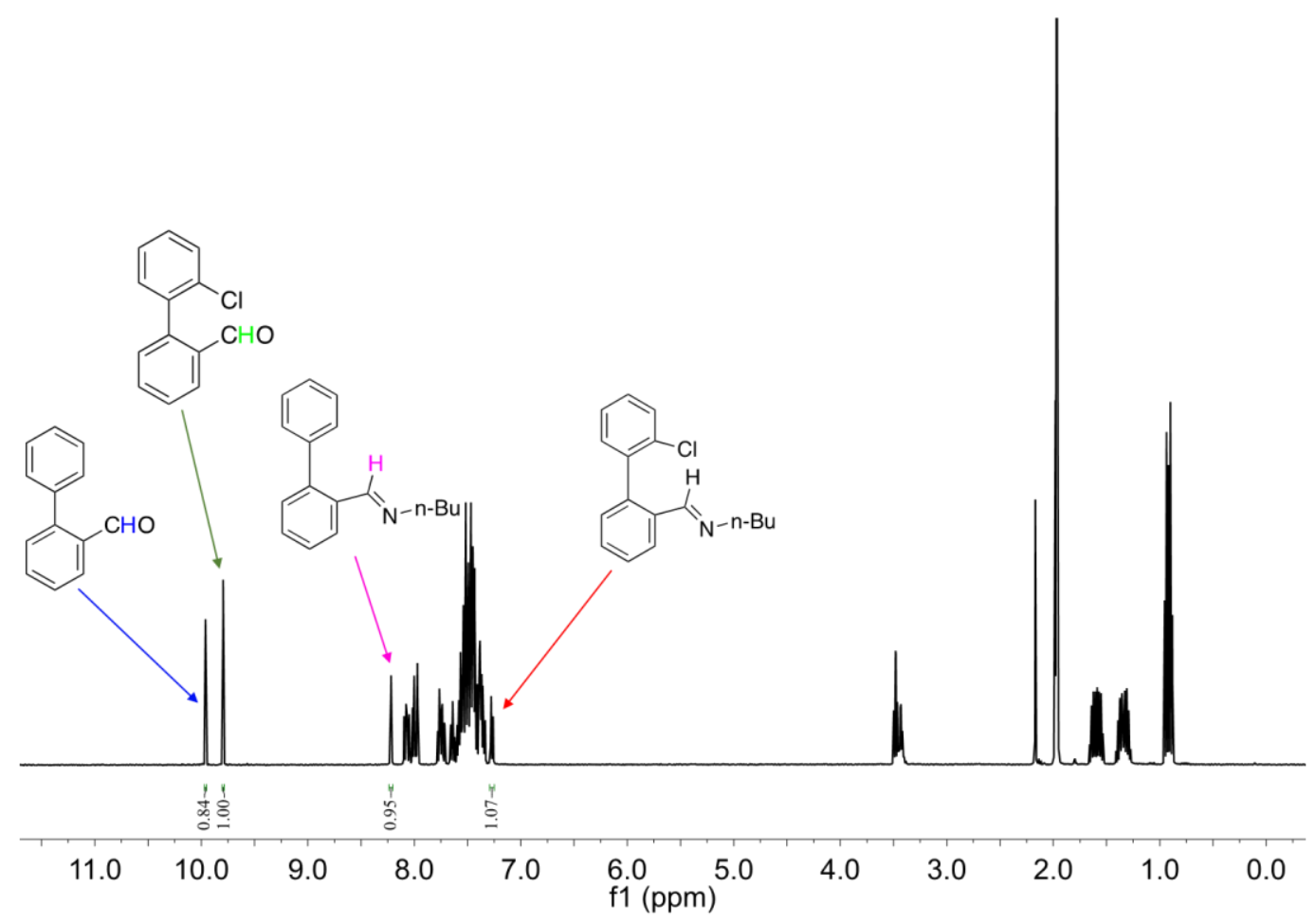

Figure S47. ${ }^{1} \mathrm{H}$ NMR spectrum of the competition between $\mathbf{1}(\mathrm{H})$ and $\mathbf{1}(\mathrm{Cl})$ for the reaction with 1-butylamine in $\mathrm{CD}_{3} \mathrm{CN}$.

a

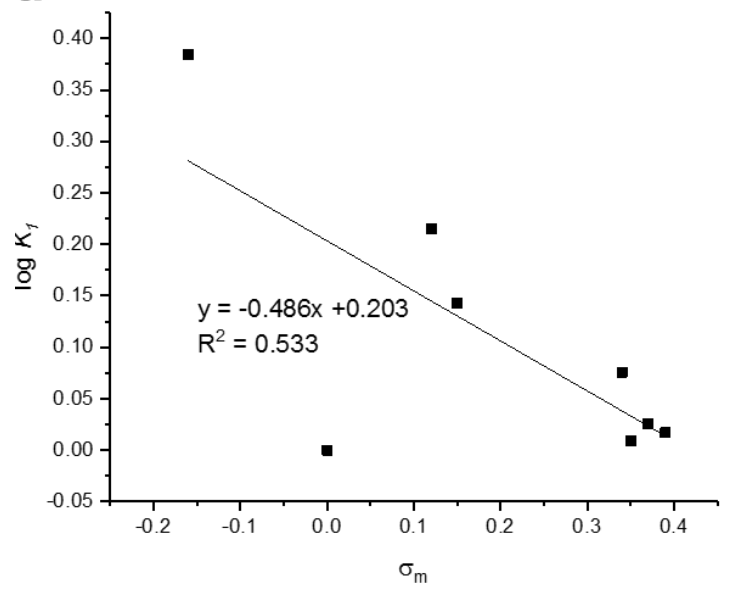

b

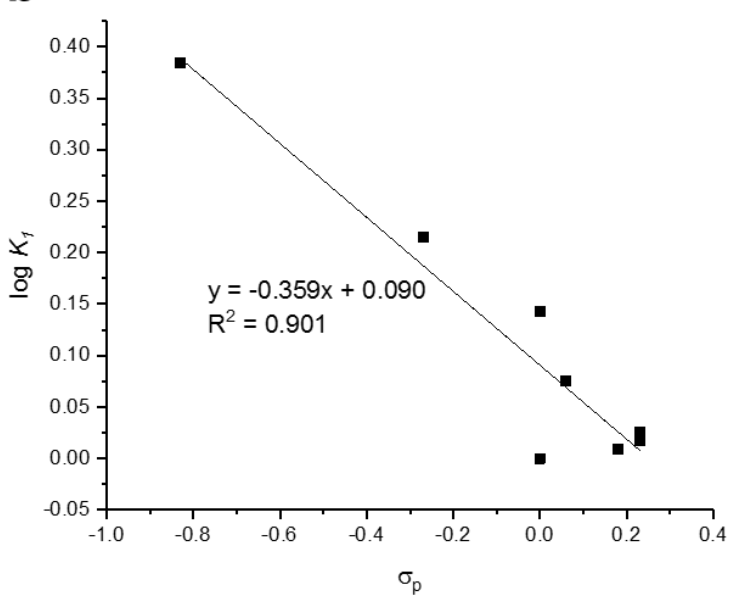

Figure S48. (a) $\log K$ of imine exchange 1 (Figure 2 and Table S3) versus $\sigma_{\mathrm{m}}$. (b) $\log$ $K$ of imine exchange 1 versus $\sigma_{\mathrm{p}}$. 


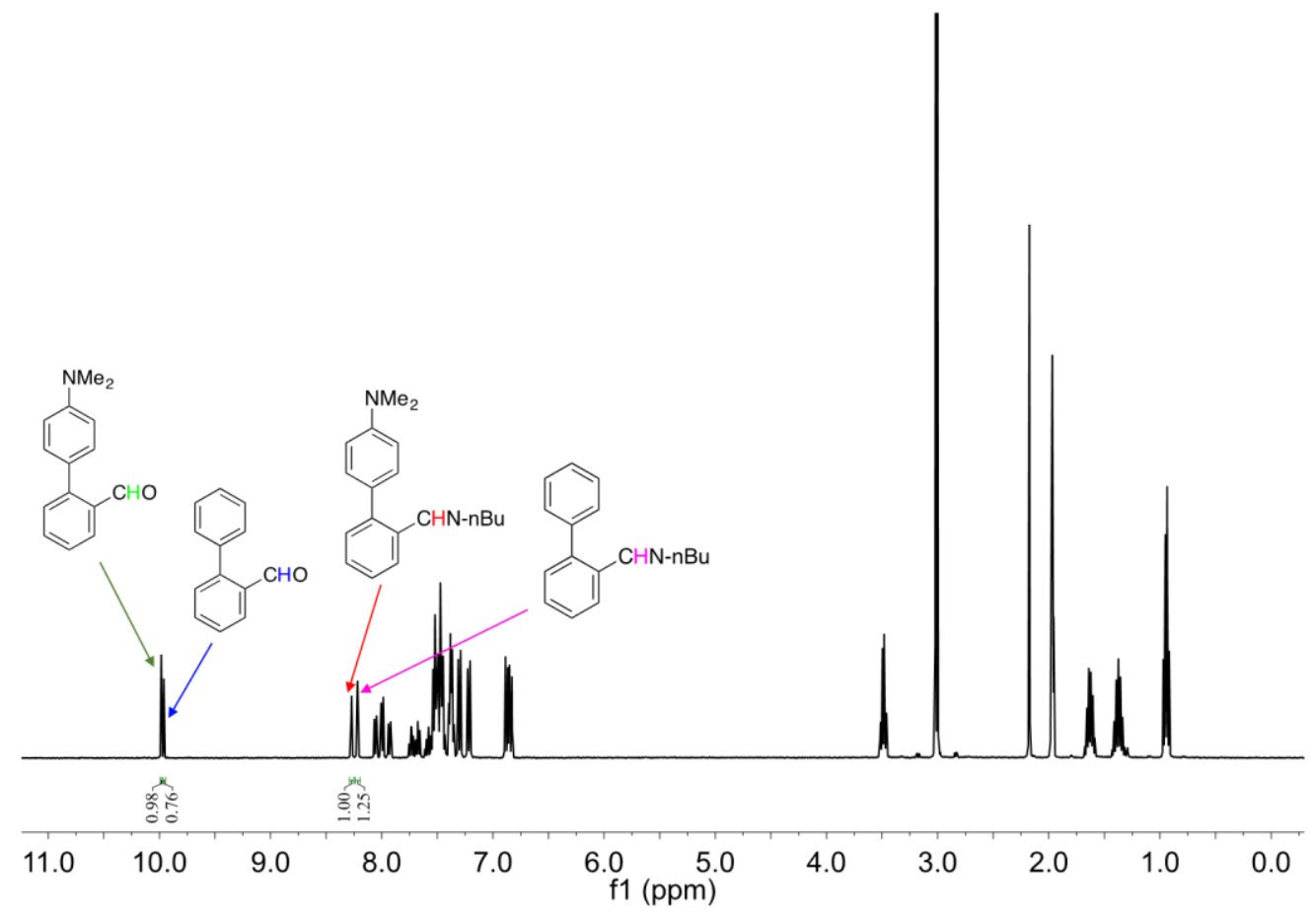

Figure S49. ${ }^{1} \mathrm{H}$ NMR spectrum of the competition between $\mathbf{1}(\mathrm{H})$ and $\mathbf{1}\left(p-\mathrm{NMe}_{2}\right)$ for the reaction with 1-butylamine in $\mathrm{CD}_{3} \mathrm{CN}$.

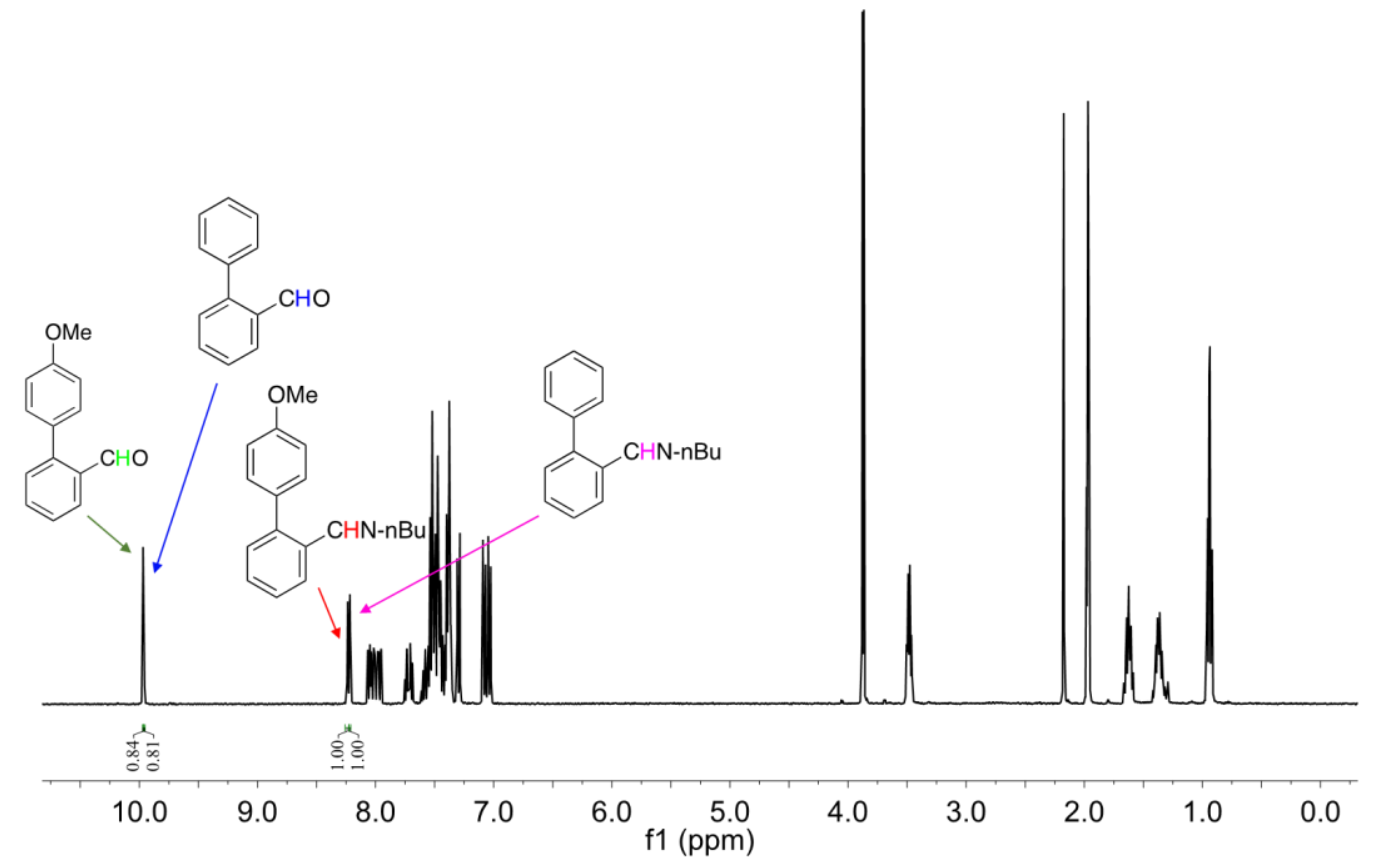

Figure S50. ${ }^{1} \mathrm{H}$ NMR spectrum of the competition between $\mathbf{1}(\mathrm{H})$ and $\mathbf{1}(p-\mathrm{OMe})$ for the reaction with 1-butylamine in $\mathrm{CD}_{3} \mathrm{CN}$. 


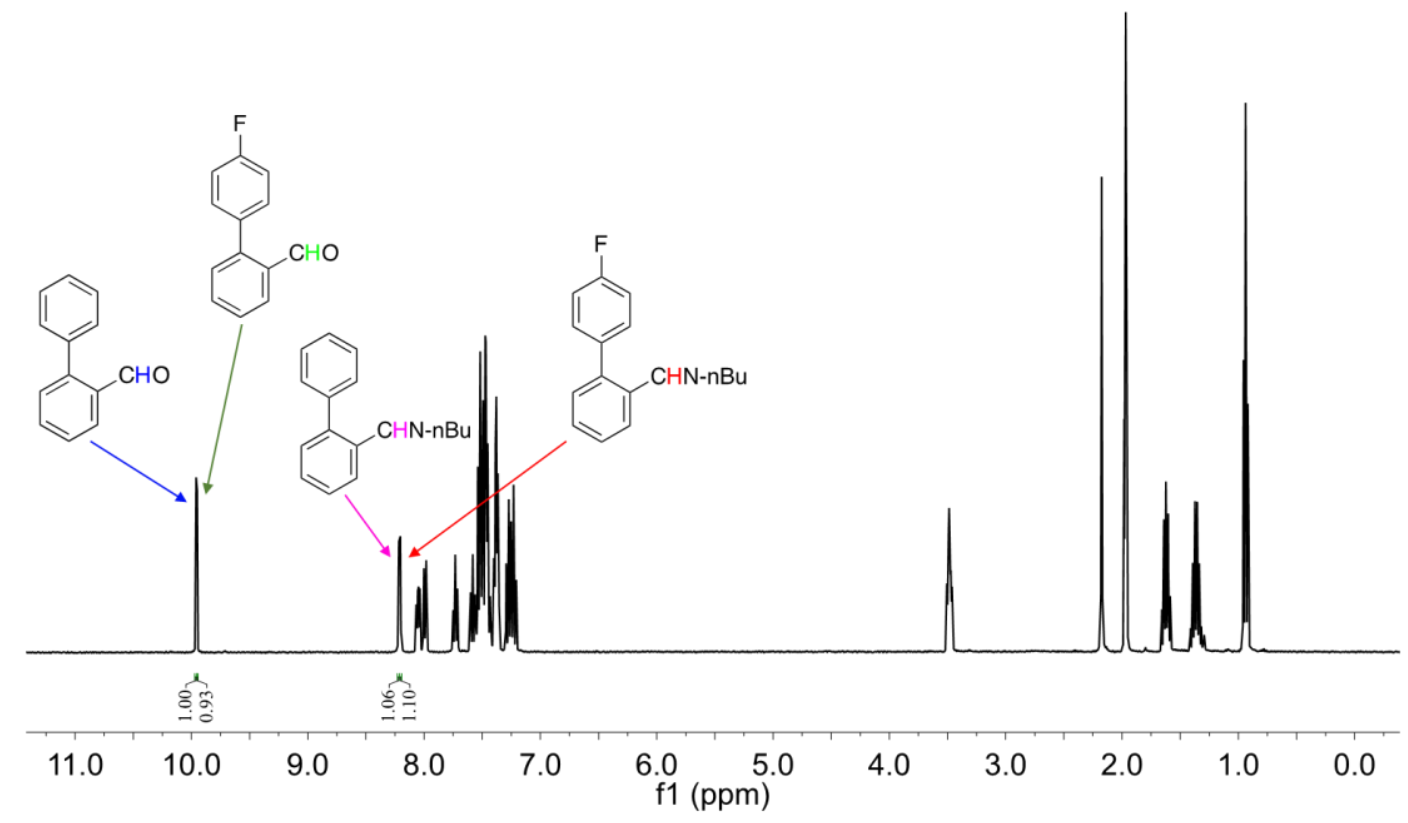

Figure S51. ${ }^{1} \mathrm{H}$ NMR spectrum of the competition between $\mathbf{1}(\mathrm{H})$ and $\mathbf{1}(p-\mathrm{F})$ for the reaction with 1-butylamine in $\mathrm{CD}_{3} \mathrm{CN}$.

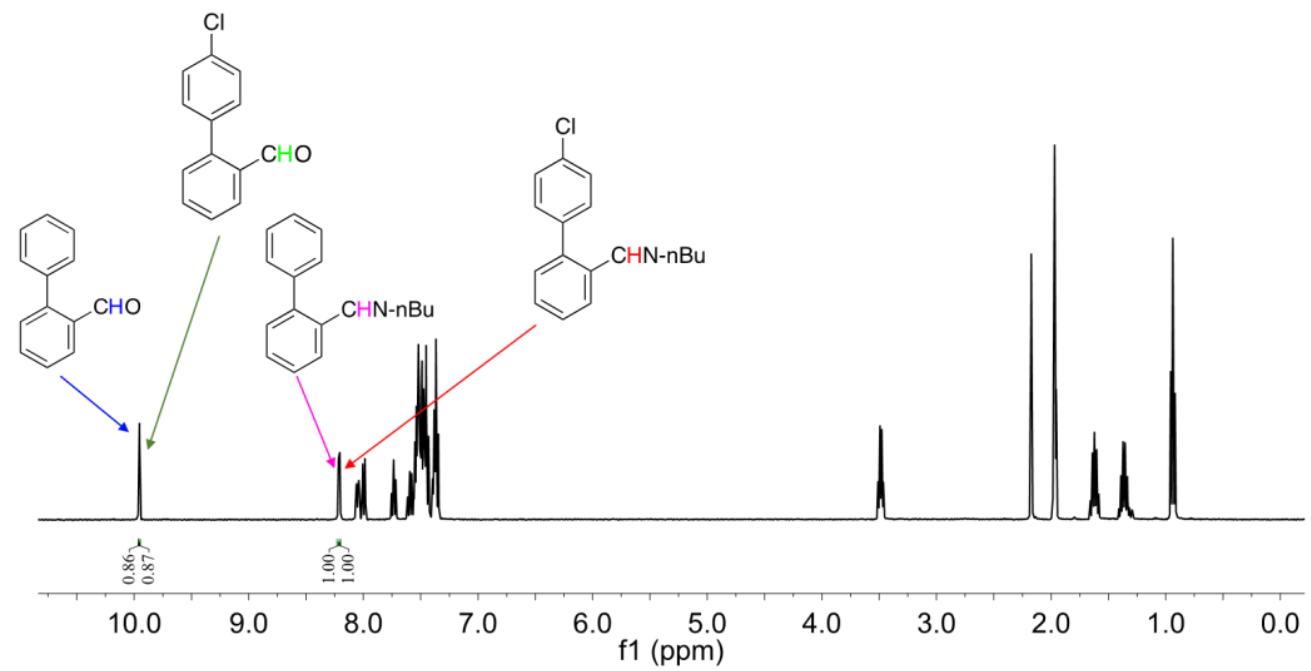

Figure S52. ${ }^{1} \mathrm{H}$ NMR spectrum of the competition between $\mathbf{1}(\mathrm{H})$ and $\mathbf{1}(p-\mathrm{Cl})$ for the reaction with 1-butylamine in $\mathrm{CD}_{3} \mathrm{CN}$. 


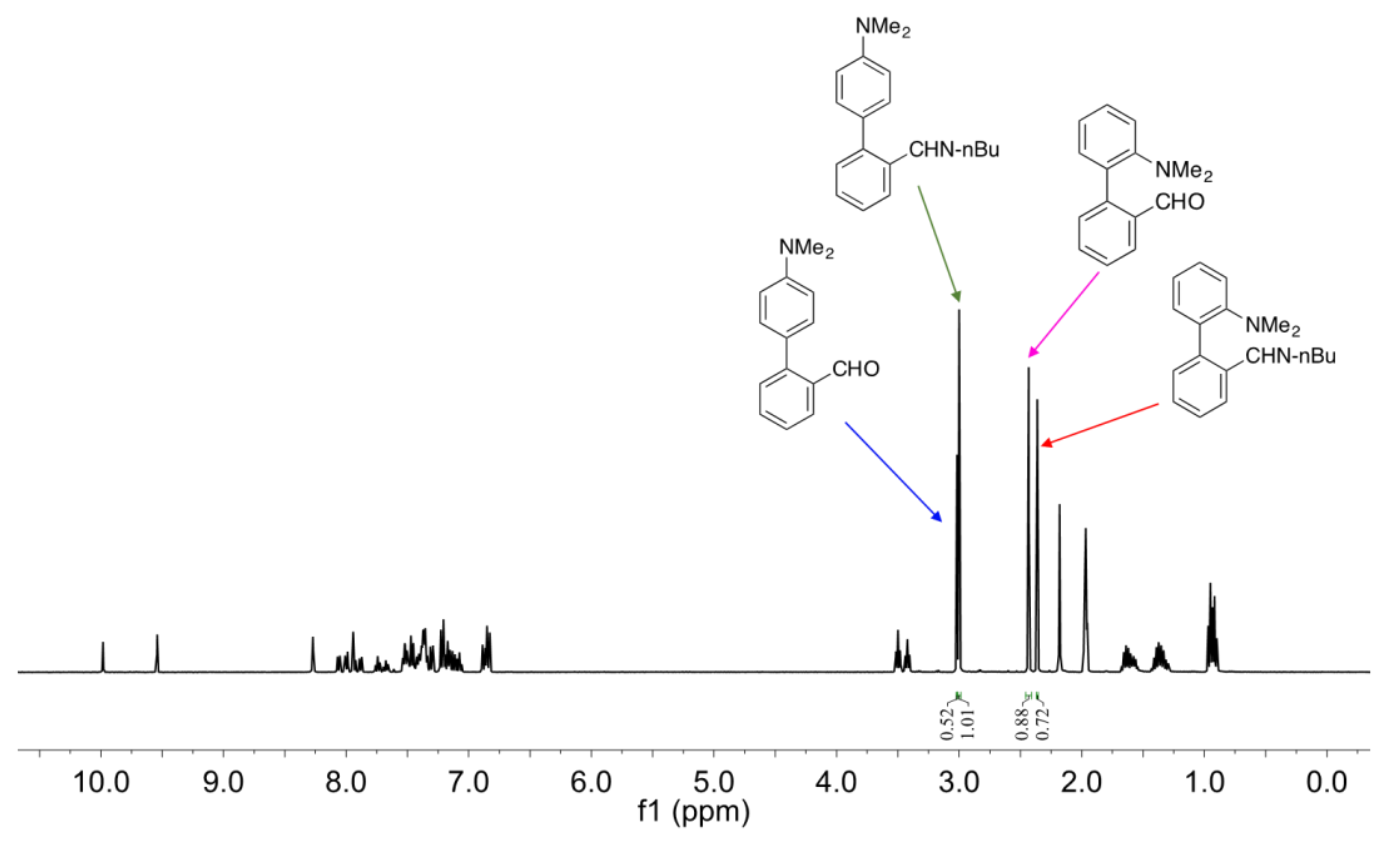

Figure S53. ${ }^{1} \mathrm{H}$ NMR spectrum of the competition between $\mathbf{1}\left(\mathrm{NMe}_{2}\right)$ and $\mathbf{1}\left(p-\mathrm{NMe}_{2}\right)$ for the reaction with 1-butylamine in $\mathrm{CD}_{3} \mathrm{CN}$.

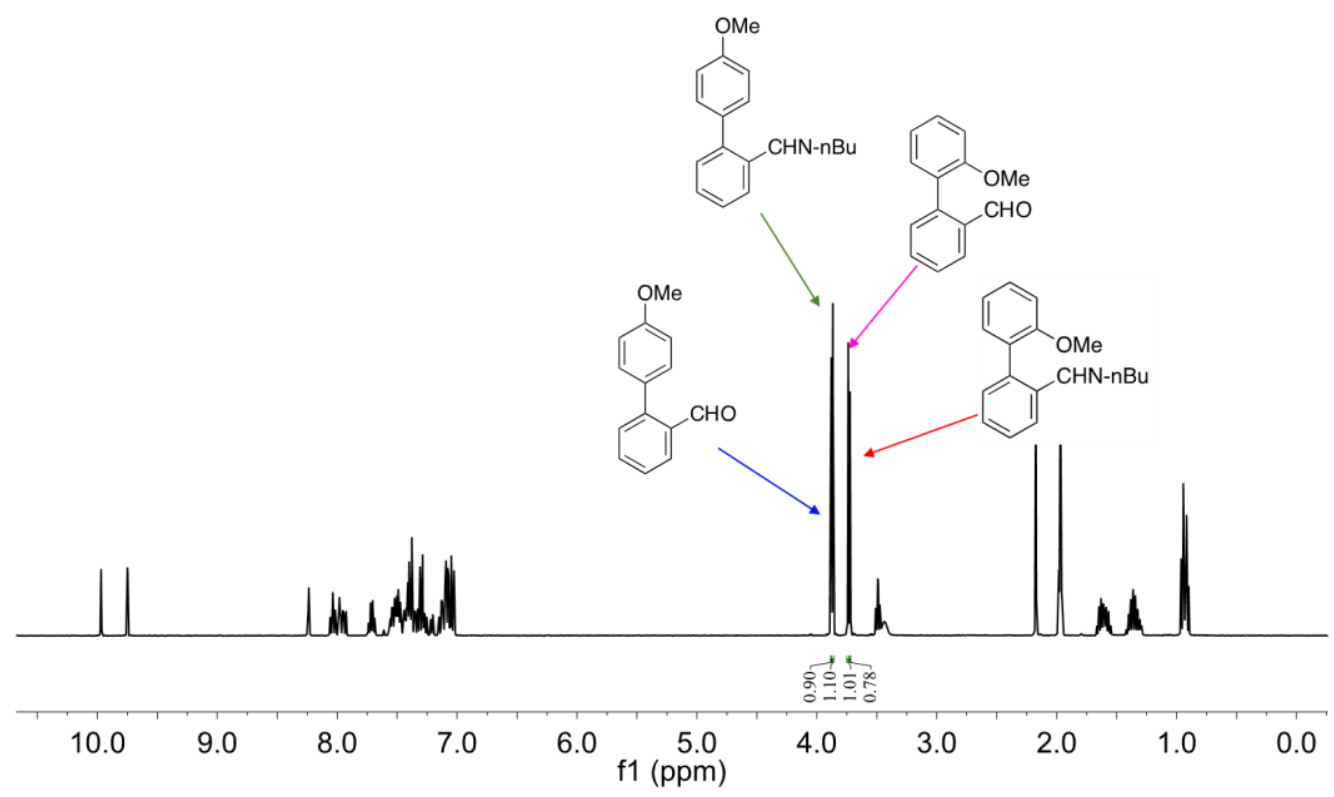

Figure S54. ${ }^{1} \mathrm{H}$ NMR spectrum of the competition between $\mathbf{1}(\mathrm{OMe})$ and $\mathbf{1}(p-\mathrm{OMe})$ for the reaction with 1-butylamine in $\mathrm{CD}_{3} \mathrm{CN}$. 


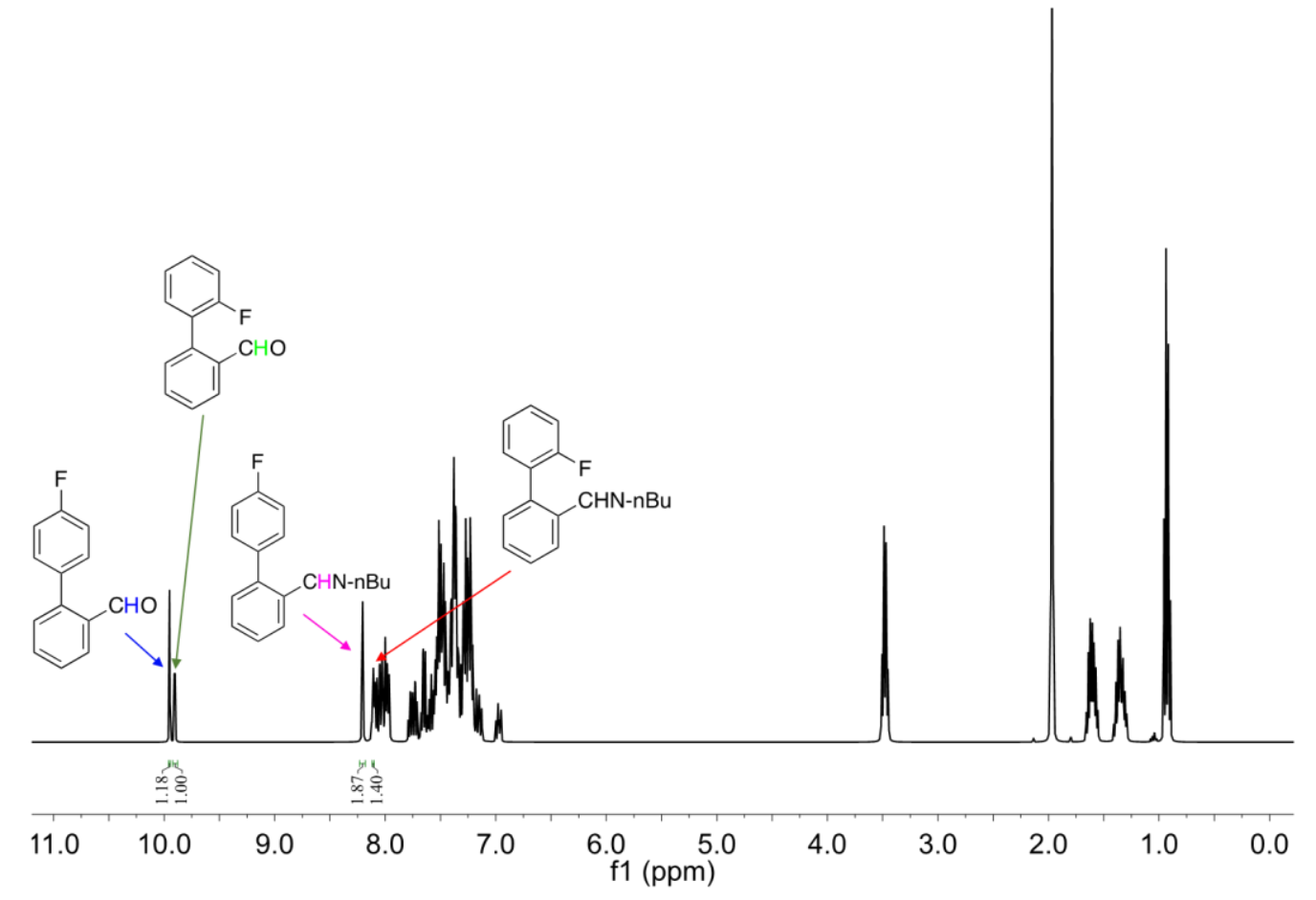

Figure S55. ${ }^{1} \mathrm{H}$ NMR spectrum of the competition between $1(\mathrm{~F})$ and $\mathbf{1}(p-\mathrm{F})$ for the reaction with 1-butylamine in $\mathrm{CD}_{3} \mathrm{CN}$.

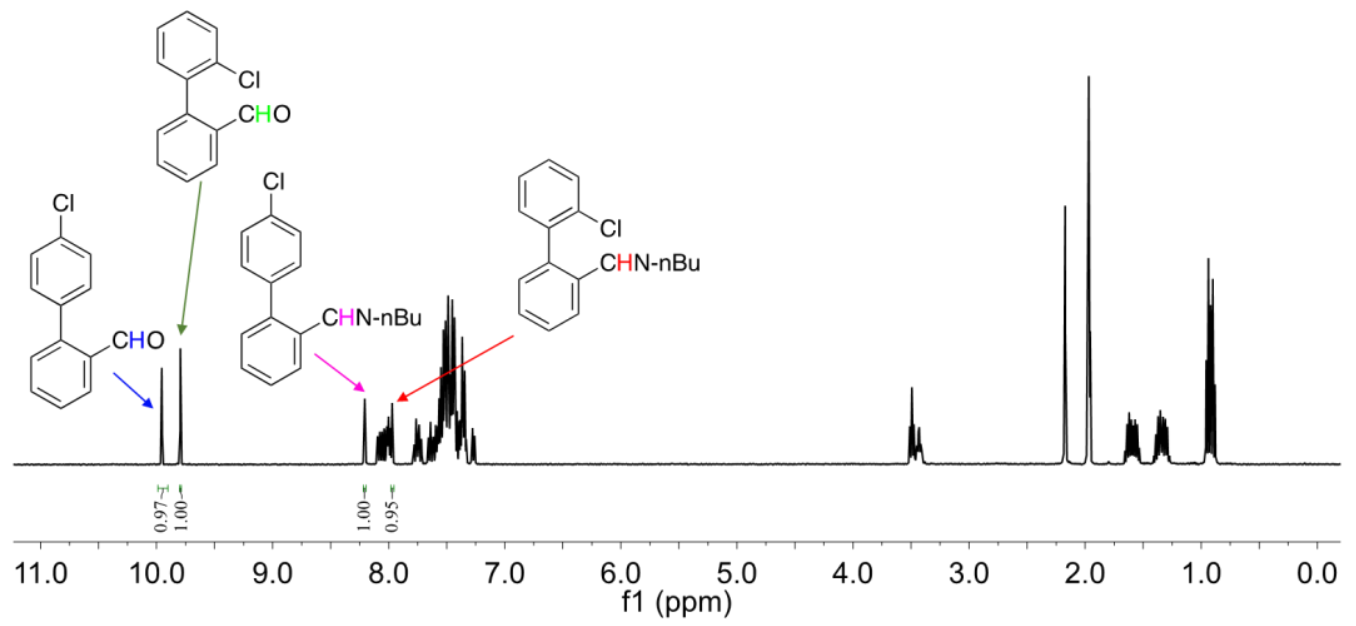

Figure S56. ${ }^{1} \mathrm{H}$ NMR spectrum of the competition between $\mathbf{1}(\mathrm{Cl})$ and $\mathbf{1}(p-\mathrm{Cl})$ for the reaction with 1-butylamine in $\mathrm{CD}_{3} \mathrm{CN}$. 


\section{Correlation with $\boldsymbol{n} \rightarrow \boldsymbol{\pi}^{*}$ Interaction}

All calculations were performed by using Gaussian 09 packages. ${ }^{\mathrm{S} 10}$ The method and basis set of M062X-D3/Def2-TZVP, M062X/Def2-TZVP, and B3LYP/Def2-TZVP was employed for the optimization and frequency analysis of model compounds $\mathbf{1}(\mathrm{X})$ and $2(\mathrm{X})\left(\mathrm{X}=\mathrm{NMe}_{2}\right.$ and $\left.\mathrm{OMe}\right)$, respectively. PCM solvent model is also included for acetonitrile. By frequency analysis, the number of imaginary frequencies for minima is 0 . Conformers 1 and 2 (with or without $n \rightarrow \pi^{*}$ interaction, Figure 3 ) were found, and the corresponding $\mathrm{G}$ were calculated. Conformers 1 and 2 were also revealed to account for more than $95 \%$ of the population of $1(\mathrm{OMe})$ and $2(\mathrm{OMe})$, respectively, and other isomers, such as Z-isomer of 2(OMe) and structures in which the carbonyl/imine points toward the other phenyl plane, were not considered further. $\triangle \mathrm{G}$ of the exchange reaction was then calculated based on Boltzmann distribution of conformers, and summarized in Table S4. Both M062X and M062X-D3 were able to correctly predict the trend of experimental substituent effect, but with D3 correction, $\triangle \mathrm{G}_{\text {cacld }}$ from M062X-D3 is more close to $\triangle \mathrm{G}_{\text {exp }}$ than M062X. Therefore, M062X-D3/Def2-TZVP (with an ultrafine integration grid) was employed for the subsequent Natural bond orbital (NBO) calculation, nocovalent interaction (NCI) analysis. In order to focus on $n \rightarrow \pi^{*}$ interaction, only conformer 1 was calculated for other X substituents. NBO was implemented by NBO 3.1 module $^{\mathrm{S} 11}$ in Gaussian 09 packages. The electronic density cubes for $\mathrm{NCI}^{\mathrm{S} 12}$ were generated by Multiwfn 3.38 using the optimized structures. ${ }^{\mathrm{S} 13} \mathrm{NBO}$ and NCI plot were presented by VMD1.90. ${ }^{\mathrm{S} 14}$

Table S4. Summary of calculated $\triangle \mathrm{G}$ with different DFT functions.

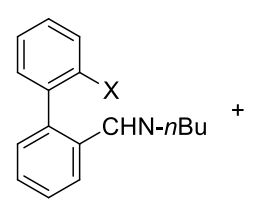

2(X)

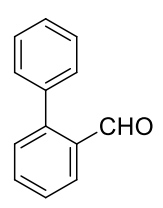

1(H)
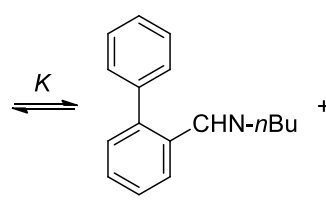

2(H)

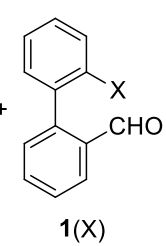

$1(X)$

\begin{tabular}{ccccc}
\hline $\mathrm{X}$ & $\begin{array}{c}\text { M062X-D3 } \\
(\mathrm{kcal} / \mathrm{mol})\end{array}$ & $\begin{array}{c}\text { M062X } \\
(\mathrm{kcal} / \mathrm{mol})\end{array}$ & $\begin{array}{c}\text { B3LYP } \\
(\mathrm{kcal} / \mathrm{mol})\end{array}$ & $\begin{array}{c}\text { Experimental } \triangle \mathrm{G} \\
(\mathrm{kcal} / \mathrm{mol})\end{array}$ \\
\hline $\mathrm{NMe}_{2}$ & -0.464 & -0.779 & -0.345 & -0.524 \\
$\mathrm{OMe}$ & -0.252 & 0.282 & -0.348 & -0.293 \\
\hline
\end{tabular}


Table S5. The values of second order stabilization energy $(\mathrm{kcal} / \mathrm{mol})$ for each natural bond orbital (based on the number of lone pairs of X) and their sums for conformer 1 of $1(X)$.

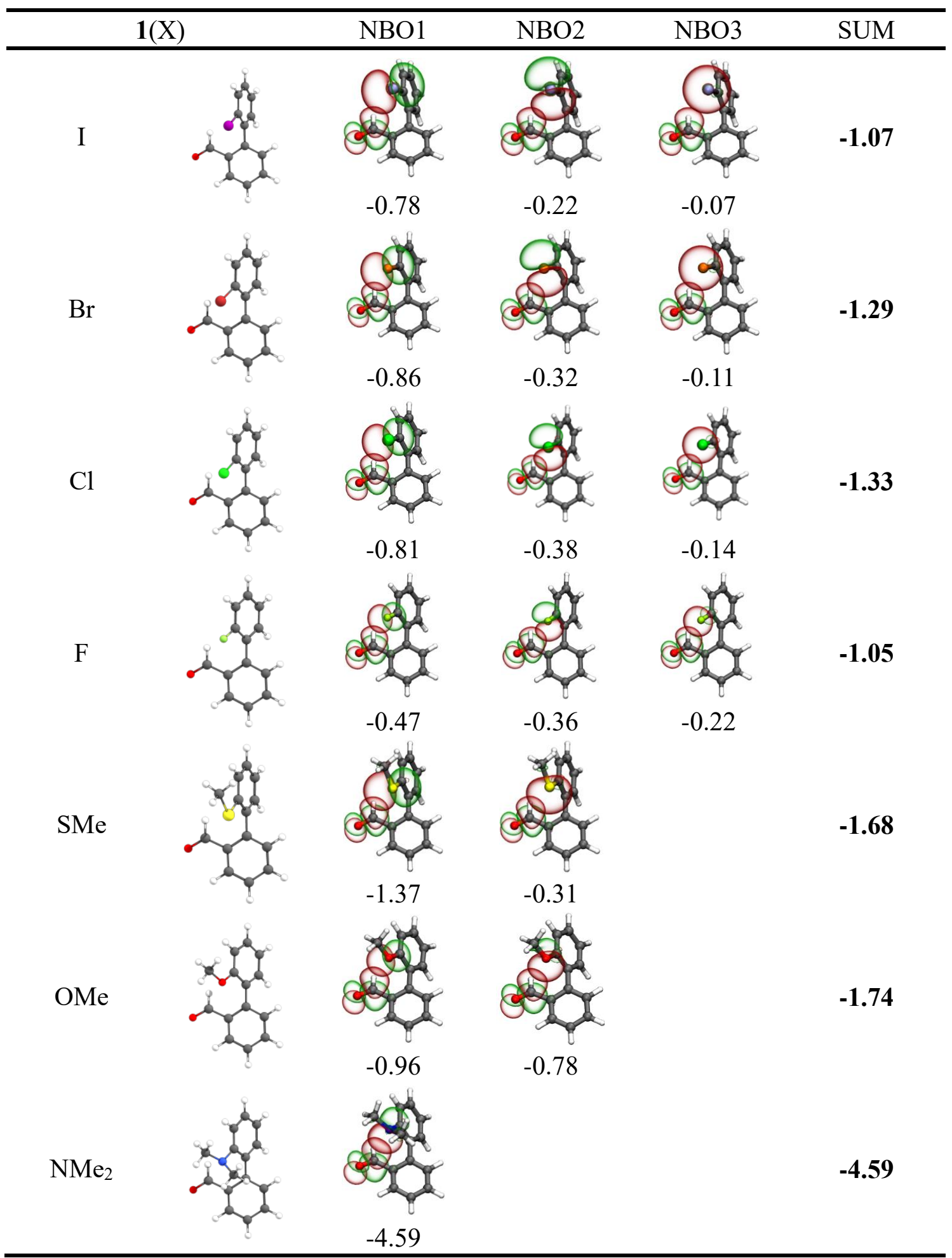


Table S6. The comparison of the values of NBOs $(\mathrm{kcal} / \mathrm{mol})$ and their sums of conformer 1 of $2(\mathrm{OMe})$ incorporating 1-butylamine or methylamine.

\begin{tabular}{|c|c|c|c|}
\hline Conformer 1 & NBO1 & $\mathrm{NBO} 2$ & SUM \\
\hline \multirow[t]{2}{*}{ methylamine } & & & -1.21 \\
\hline & -0.66 & -0.55 & \\
\hline \multirow[t]{2}{*}{ 1-butylamine } & & & -1.22 \\
\hline & -0.68 & -0.54 & \\
\hline
\end{tabular}

Table S7. The values of second order stabilization energy $(\mathrm{kcal} / \mathrm{mol})$ for each natural bond orbital and their sums for conformer 1 of $2(X)$.

$2(\mathrm{X})$ NBO1 $\mathrm{NBO}$ SUM



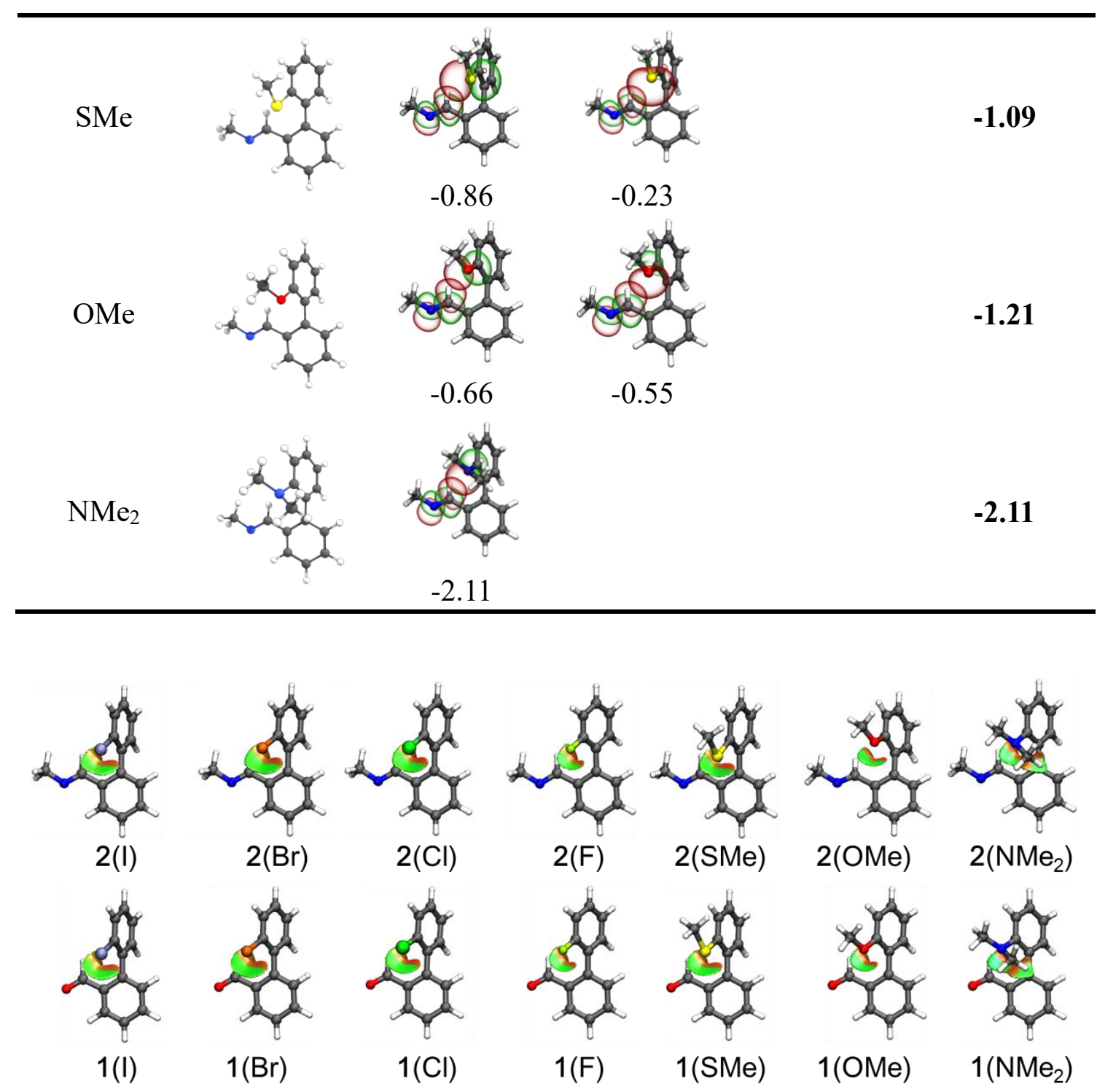

Figure S57. The NCI plot of conformer 1 for $\mathbf{1}(\mathrm{X})$ and $\mathbf{2}(\mathrm{X})$. For clarity only focused interactions were shown.

Table S8. The values of the sterimol parameters ( $\mathrm{L}$ and $\mathrm{B} 1$, in $10^{-10} \mathrm{~m}$ ), the stabilization energy difference $\left(\triangle \triangle E^{(2)}\right.$ a) between conformer 1 of $\mathbf{1}(X)$ and $2(X)$ for multivariate correlation, as well as predicted and measured $\Delta \mathrm{G}^{\mathrm{b}}$ of imine exchange. The units of $\Delta \mathrm{E}^{(2)}$ and $\Delta \mathrm{G}$ are $\mathrm{kcal} / \mathrm{mol}$. The predicted $\Delta \mathrm{G}$ value was calculated based on multivariate linear correlation of measured $\triangle \mathrm{G}$ versus L, B1, and $\triangle \triangle \mathrm{E}^{(2)}$.

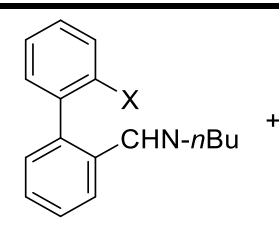

2(X)

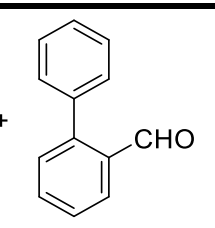

$1(\mathrm{H})$

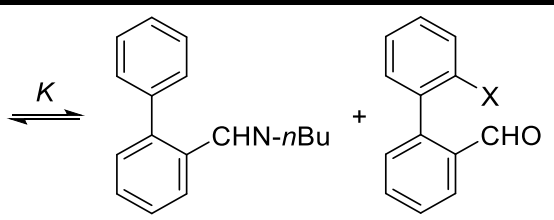

2(H)
$1(\mathrm{X})$ 


\begin{tabular}{cccccccc}
\hline $\mathrm{X}$ & $\mathrm{L}$ & $\mathrm{B}_{1}$ & $\triangle \mathrm{E}^{(2)}-\mathbf{1}(\mathrm{X})$ & $\Delta \mathrm{E}^{(2)} \mathbf{- 2}(\mathrm{X})$ & $\triangle \triangle \mathrm{E}^{(2) \mathrm{a}}$ & $\begin{array}{c}\text { Predicted } \\
\Delta \mathrm{G}\end{array}$ & $\begin{array}{c}\text { Measured } \\
\Delta \mathrm{G}^{\mathrm{b}}\end{array}$ \\
\hline $\mathrm{F}$ & 2.65 & 1.35 & -1.05 & -0.94 & -0.11 & -0.095 & -0.103 \\
$\mathrm{Cl}$ & 3.52 & 1.80 & -1.33 & -1.06 & -0.27 & -0.052 & -0.035 \\
$\mathrm{Br}$ & 3.83 & 1.95 & -1.29 & -0.98 & -0.31 & -0.038 & -0.023 \\
$\mathrm{I}$ & 4.23 & 2.15 & -1.07 & -0.89 & -0.18 & 0.014 & -0.012 \\
$\mathrm{NMe}_{2}$ & 3.53 & 1.50 & -4.59 & -2.11 & -2.48 & -0.521 & -0.524 \\
$\mathrm{SMe}$ & 4.30 & 1.70 & -1.68 & -1.09 & -0.59 & -0.209 & -0.195 \\
$\mathrm{OMe}$ & 3.98 & 1.35 & -1.74 & -1.21 & -0.53 & -0.285 & -0.293 \\
\hline $\mathrm{a} \triangle \triangle \mathrm{E}^{(2)}=\left[\triangle \mathrm{E}^{(2)}-1(\mathrm{X})\right]-\left[\triangle \mathrm{E}^{(2)}-\mathbf{2}(\mathrm{X})\right]$ & & & &
\end{tabular}

${ }^{\mathrm{a}} \triangle \triangle \mathrm{E}^{(2)}=\left[\triangle \mathrm{E}^{(2)}-\mathbf{1}(\mathrm{X})\right]-\left[\triangle \mathrm{E}^{(2)}-\mathbf{2}(\mathrm{X})\right]$

${ }^{\mathrm{b}}$ Measured $\triangle \mathrm{G}=-0.281-0.0900 \mathrm{~L}+0.328 \mathrm{~B} 1+0.167 \triangle \triangle \mathrm{E}^{(2)}$

The quality of multivariate linear regression of measured $\triangle \mathrm{G}$ versus $\mathrm{L}, \mathrm{B}_{1}$, and $\triangle \triangle \mathrm{E}^{(2)}$ was supported by a good linear relationship (Measured $\triangle \mathrm{G}=1.0001 *$ (Predicted $\triangle \mathrm{G})+8.06 * 10^{-7}, \mathrm{R}^{2}=0.993$, as shown in Figure $4 \mathrm{f}$ ) between the experimental and the predicted data. By using a standardization method of regression coefficient, the distribution of $L, B_{1}$, and $\triangle \triangle E^{(2)}$ can be determined by their corresponding values of regression coefficient of $-0.270,0.535,0.742$, respectively. 


\section{Solvent Effect}

\section{(1) Solvent effect on thermodynamics}

Aldehydes $\mathbf{1}(\mathrm{H})$ and $\mathbf{1}(\mathrm{OMe})$ (20 $\mathrm{mM}$ each, 1.0 equiv.) were mixed with 1-butylamine (24 mM, 1.2 equiv.) in different solvents $(0.6 \mathrm{~mL})$, and the mixture was stirred overnight in the presence of molecular sieves and characterized by ${ }^{1} \mathrm{H}$ NMR. For reactions in aqueous media, aldehydes $\mathbf{3}(\mathrm{H})$ and $\mathbf{3}(\mathrm{OMe})(40 \mathrm{mM}$ each) were used. The equilibrium constant of imine exchange was next calculated. The data is listed in Table S9, with representative NMR spectra shown in Figures S58-S64.

Table S9. Solvent parameters, ${ }^{\mathrm{S} 15} K$, measured $\Delta \mathrm{G}$ of exchange reactions. Solvent mixtures are reported in $\mathrm{v} / \mathrm{v} \%$. Cohesive energy density (ced) for solvent mixtures are calculated assuming these values scale linearly with the $\mathrm{v} / \mathrm{v} \%$ solvent composition.

\begin{tabular}{|c|c|c|c|c|}
\hline Solvent & $\operatorname{ced}\left(\mathrm{cal} / \mathrm{cm}^{3}\right)$ & $\alpha$ & $\boldsymbol{K}$ & $\begin{array}{c}\Delta \mathbf{G}_{\text {exp. }} \\
(\mathrm{kcal} / \mathrm{mol})\end{array}$ \\
\hline Toluene & 79.4 & 0 & 0.71 & 0.203 \\
\hline Chloroform & 85.4 & 0.2 & 0.72 & 0.194 \\
\hline Dichloromethane & 93.7 & 0.13 & 0.78 & 0.147 \\
\hline $\begin{array}{c}60 \% \mathrm{CDCl}_{3} \\
40 \% \mathrm{CD}_{3} \mathrm{CN}\end{array}$ & 106.8 & & 1.03 & -0.017 \\
\hline Pyridine & 112.4 & 0 & 1.24 & -0.127 \\
\hline $\begin{array}{c}20 \% \mathrm{CDCl}_{3} \\
80 \% \mathrm{CD}_{3} \mathrm{CN}\end{array}$ & 128.2 & & 1.47 & -0.228 \\
\hline Acetonitrile & 138.9 & 0.19 & 1.64 & -0.293 \\
\hline DMF & 139.2 & 0 & 2.10 & -0.439 \\
\hline DMSO & 168.6 & 0 & 2.99 & -0.648 \\
\hline Isopropanol & 132.3 & 0.76 & 1.70 & -0.314 \\
\hline Ethanol & 161.3 & 0.86 & 1.46 & -0.224 \\
\hline Methanol & 209 & 0.98 & 1.22 & -0.118 \\
\hline $\begin{array}{c}80 \% \mathrm{CD}_{3} \mathrm{OD} \\
20 \% \mathrm{D}_{2} \mathrm{O}\end{array}$ & 277.2 & & 1.04 & -0.023 \\
\hline $\begin{array}{c}60 \% \mathrm{CD}_{3} \mathrm{OD} \\
40 \% \mathrm{D}_{2} \mathrm{O}\end{array}$ & 345.4 & & 0.88 & 0.076 \\
\hline $\begin{array}{c}40 \% \mathrm{CD}_{3} \mathrm{OD} \\
60 \% \mathrm{D}_{2} \mathrm{O}\end{array}$ & 413.6 & & 0.68 & 0.228 \\
\hline $\begin{array}{c}20 \% \mathrm{CD}_{3} \mathrm{OD} \\
80 \% \mathrm{D}_{2} \mathrm{O}\end{array}$ & 481.8 & & 0.53 & 0.375 \\
\hline $\mathrm{D}_{2} \mathrm{O}$ & 550 & 1.17 & 0.44 & 0.486 \\
\hline
\end{tabular}




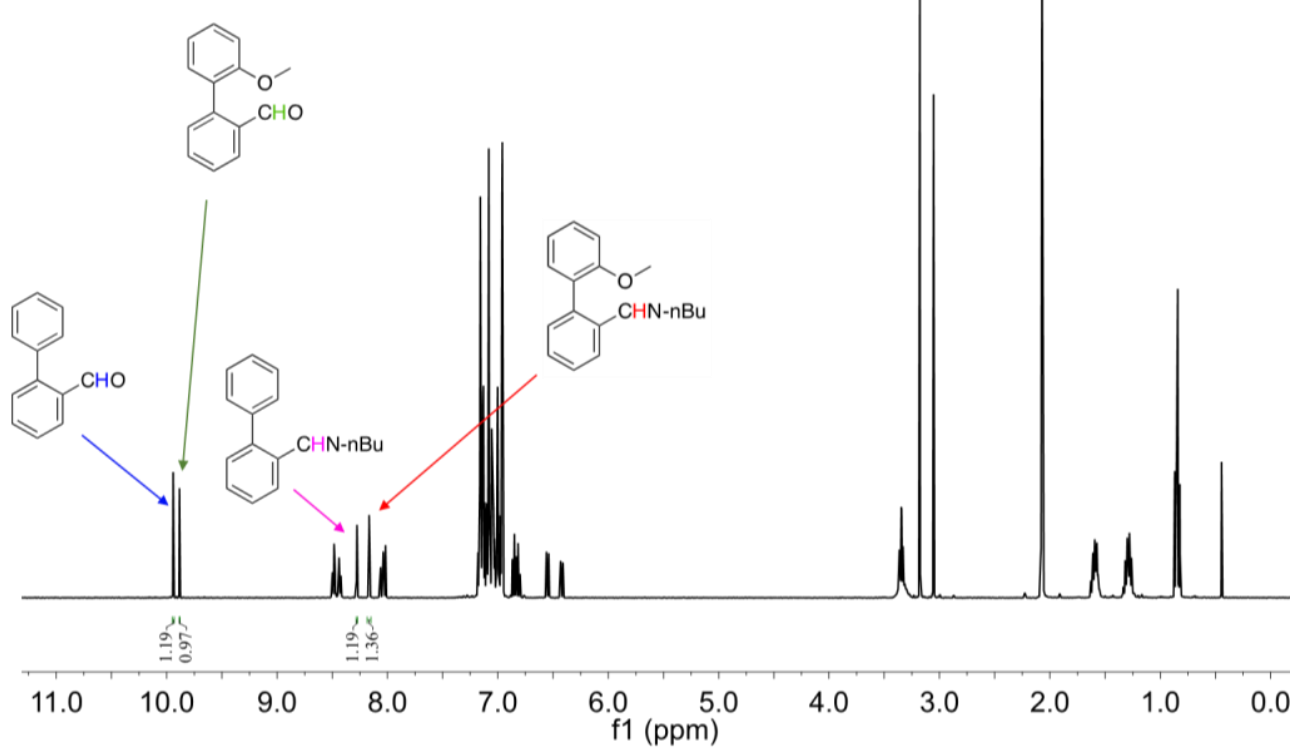

Figure S58. ${ }^{1} \mathrm{H}$ NMR spectrum of the competition between $\mathbf{1}(\mathrm{H})$ and $\mathbf{1}(\mathrm{OMe})$ for the reaction with 1-butylamine in toluene- $\mathrm{d}_{8}$.

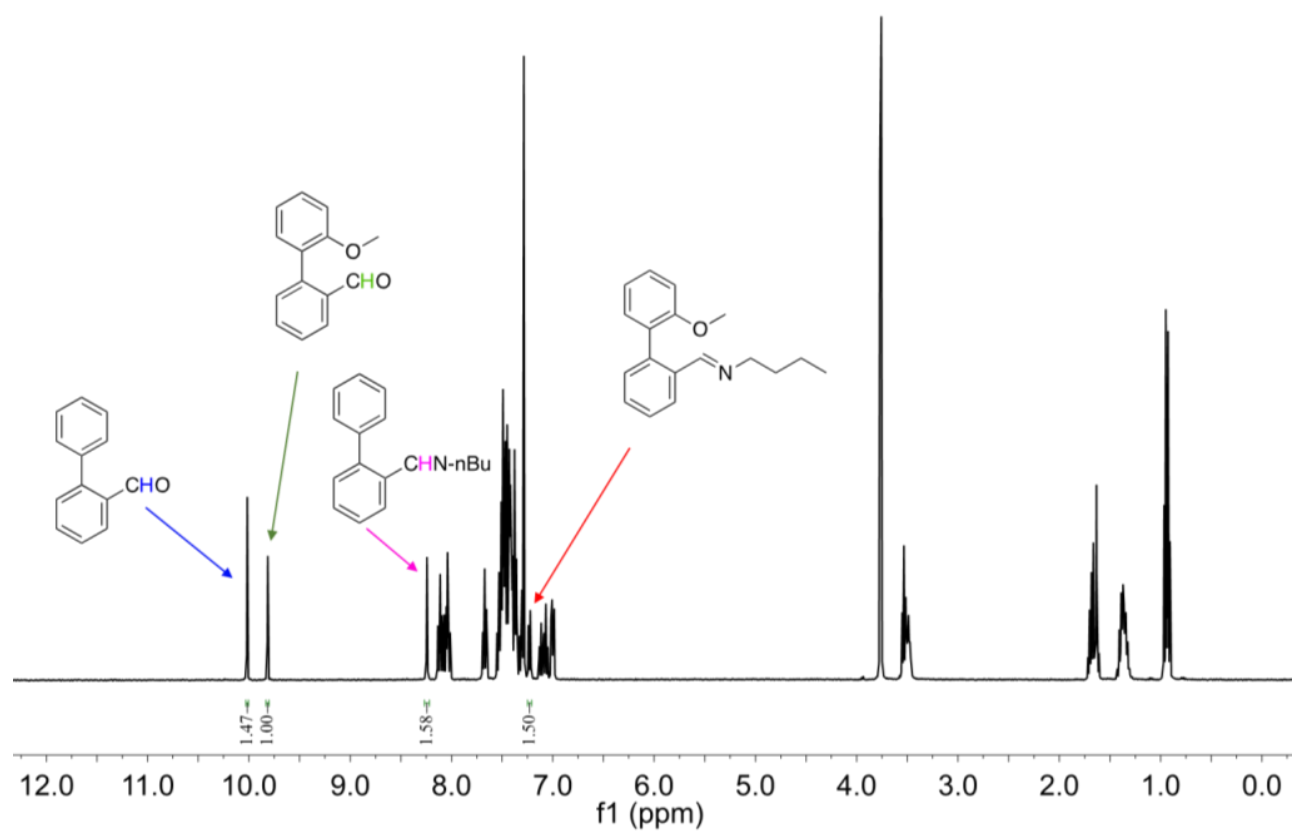

Figure S59. ${ }^{1} \mathrm{H}$ NMR spectrum of the competition between $\mathbf{1}(\mathrm{H})$ and $\mathbf{1}(\mathrm{OMe})$ for the reaction with 1-butylamine in $\mathrm{CDCl}_{3}$. 


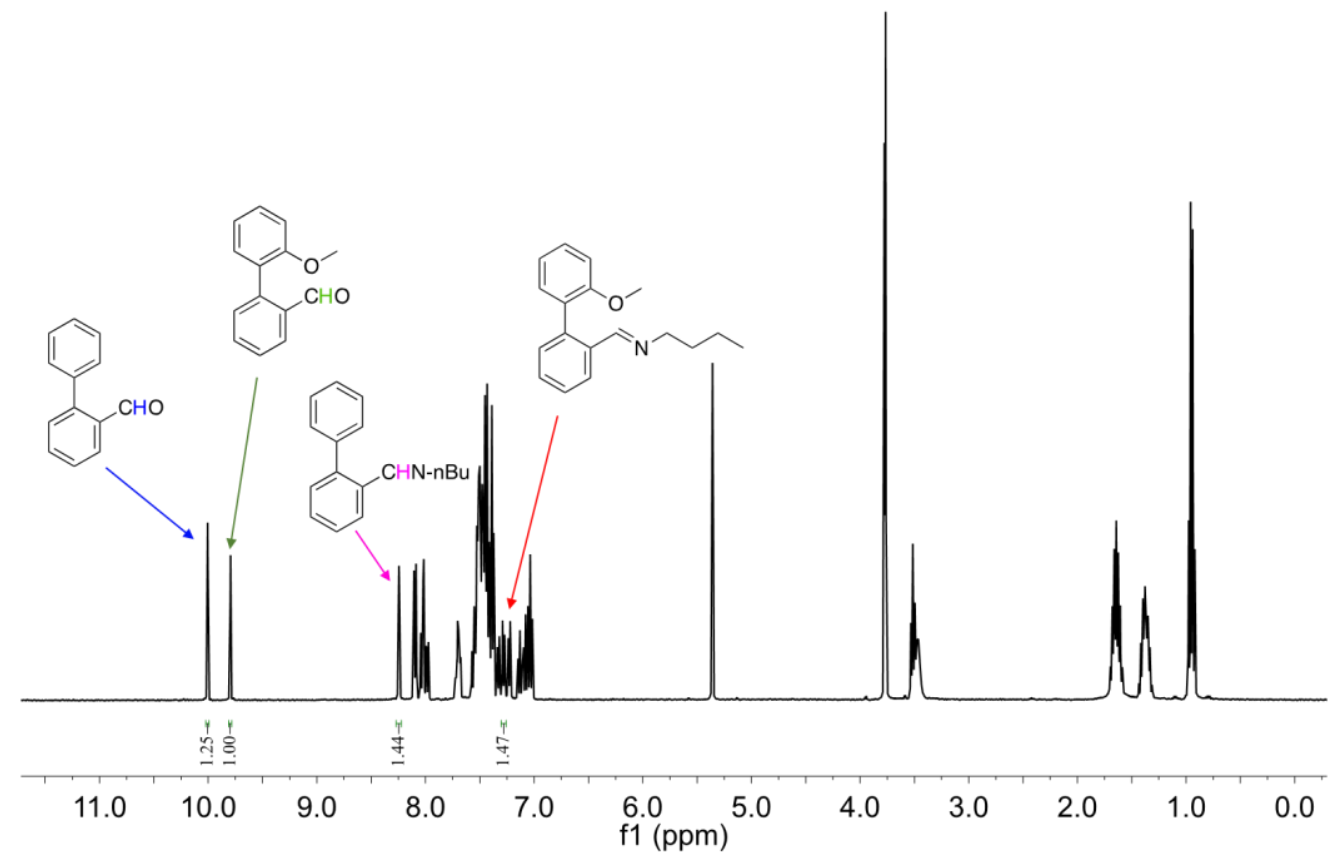

Figure S60. ${ }^{1} \mathrm{H}$ NMR spectrum of the competition between $\mathbf{1}(\mathrm{H})$ and $\mathbf{1}(\mathrm{OMe})$ for the reaction with 1-butylamine in $\mathrm{CD}_{2} \mathrm{Cl}_{2}$.

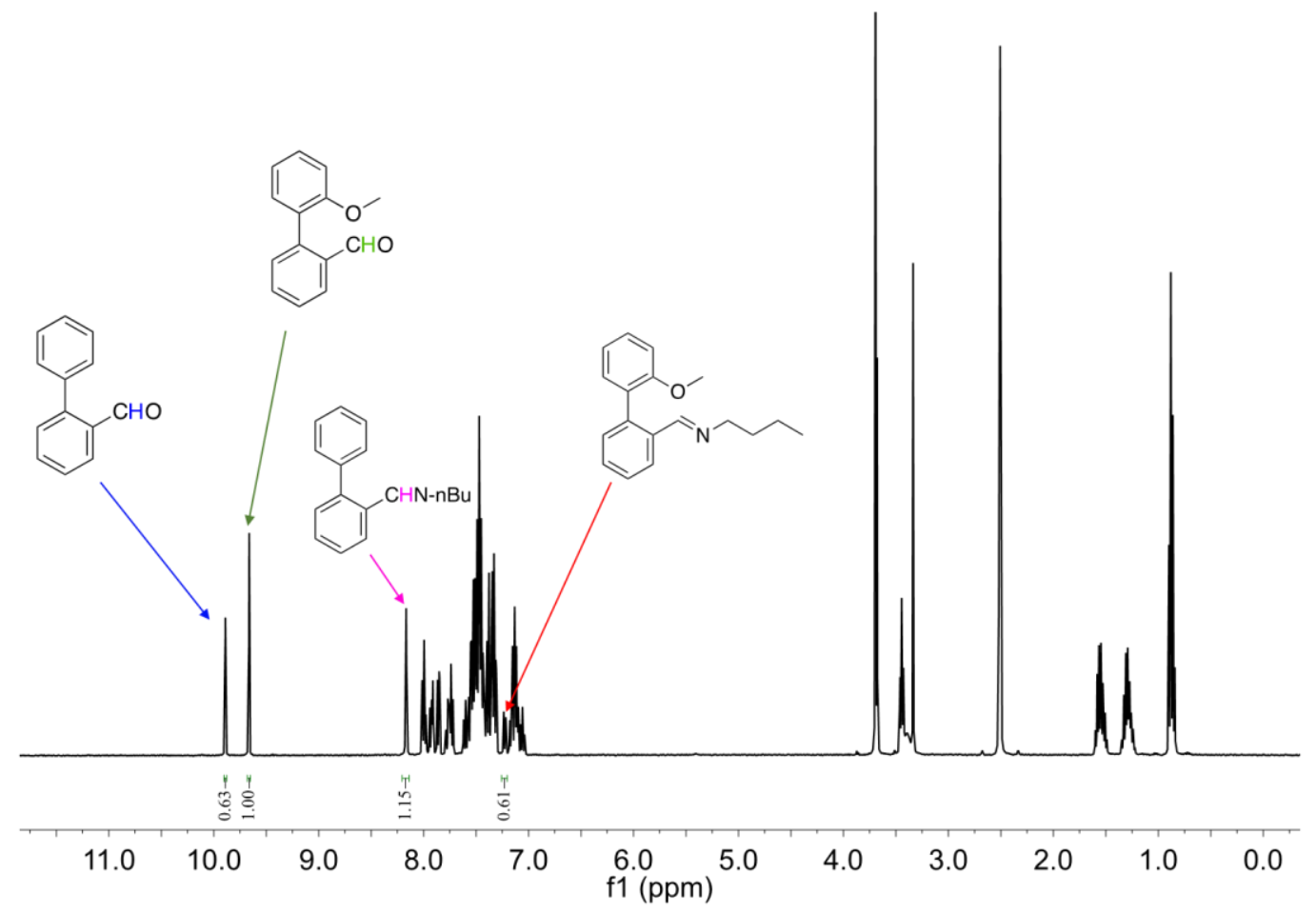

Figure S61. ${ }^{1} \mathrm{H}$ NMR spectrum of the competition between $\mathbf{1}(\mathrm{H})$ and $\mathbf{1}(\mathrm{OMe})$ for the reaction with 1-butylamine in DMSO-d 6 . 


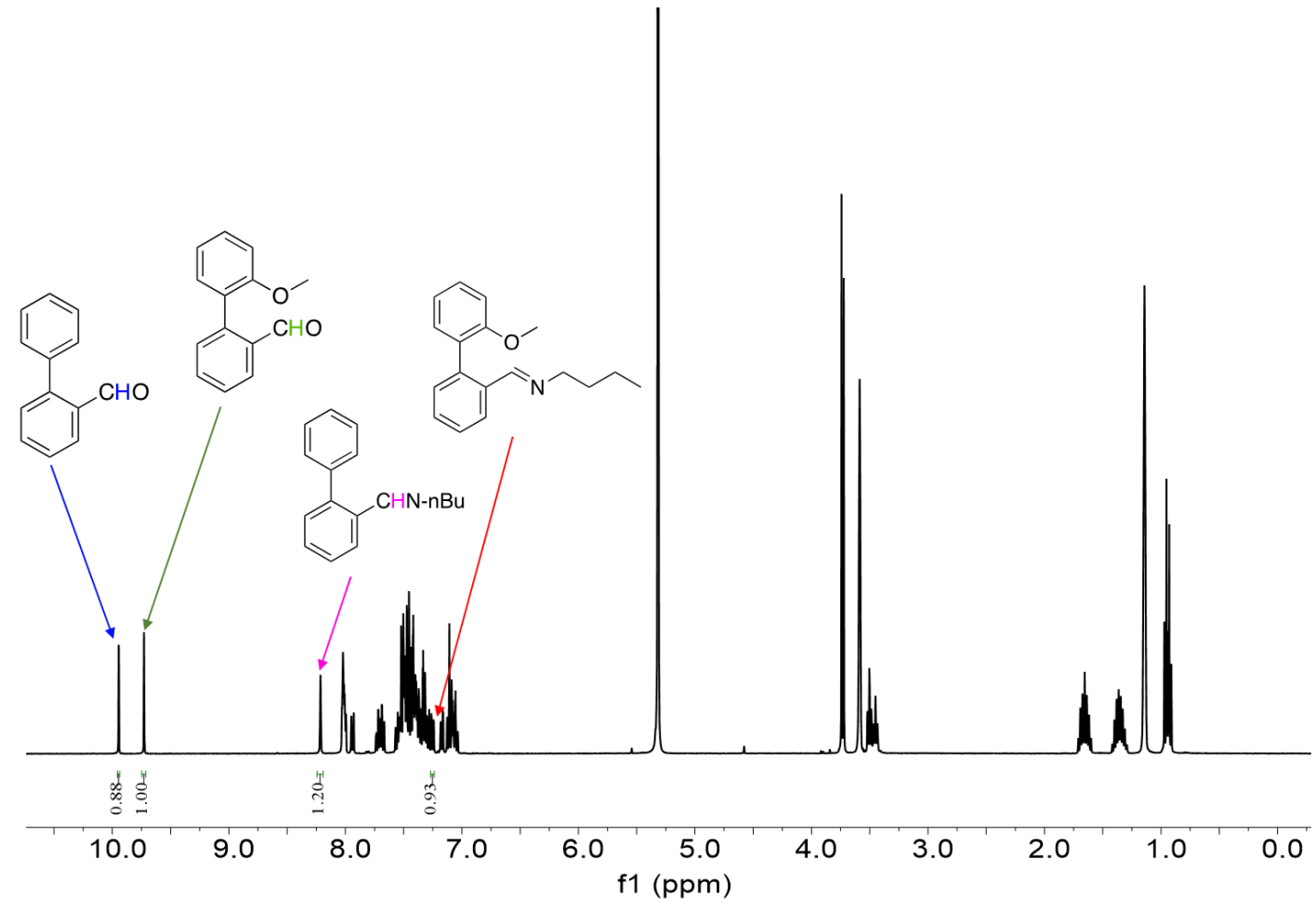

Figure S62. ${ }^{1} \mathrm{H}$ NMR spectrum of the competition between $\mathbf{1}(\mathrm{H})$ and $\mathbf{1}(\mathrm{OMe})$ for the reaction with 1-butylamine in ethanol- $\mathrm{d}_{6}$.

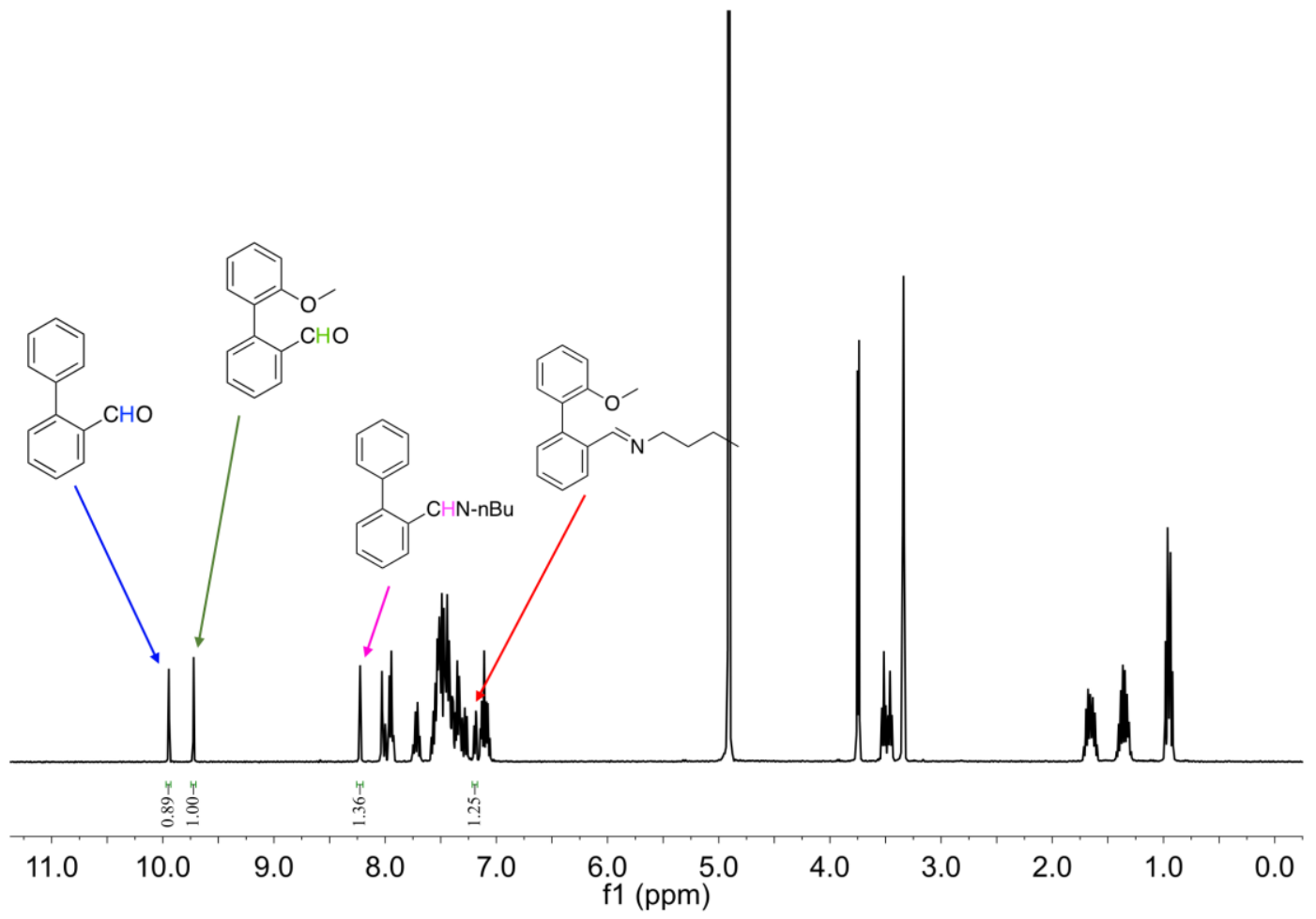

Figure S63. ${ }^{1} \mathrm{H}$ NMR spectrum of the competition between $\mathbf{1}(\mathrm{H})$ and $\mathbf{1}(\mathrm{OMe})$ for the reaction with 1-butylamine in $\mathrm{CD}_{3} \mathrm{OD}$ (the corresponding spectra of panel $\mathrm{c}$ in Table S10). 


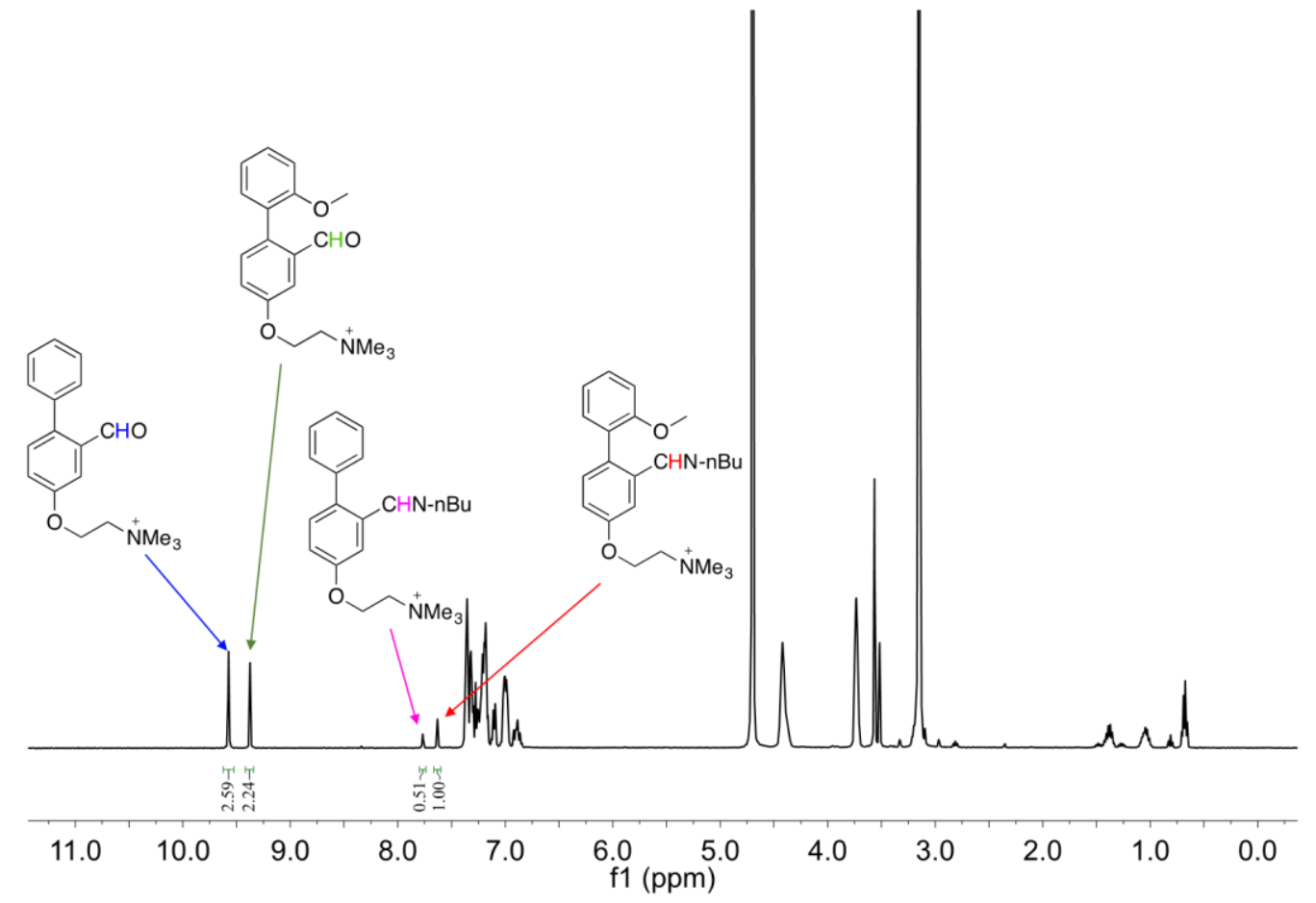

Figure S64. ${ }^{1} \mathrm{H}$ NMR spectrum of the competition between $3(\mathrm{H})$ and $3(\mathrm{OMe})$ for the reaction with 1-butylamine in $\mathrm{D}_{2} \mathrm{O}$ (the corresponding spectra of panel $\mathrm{f}$ in Table S10).

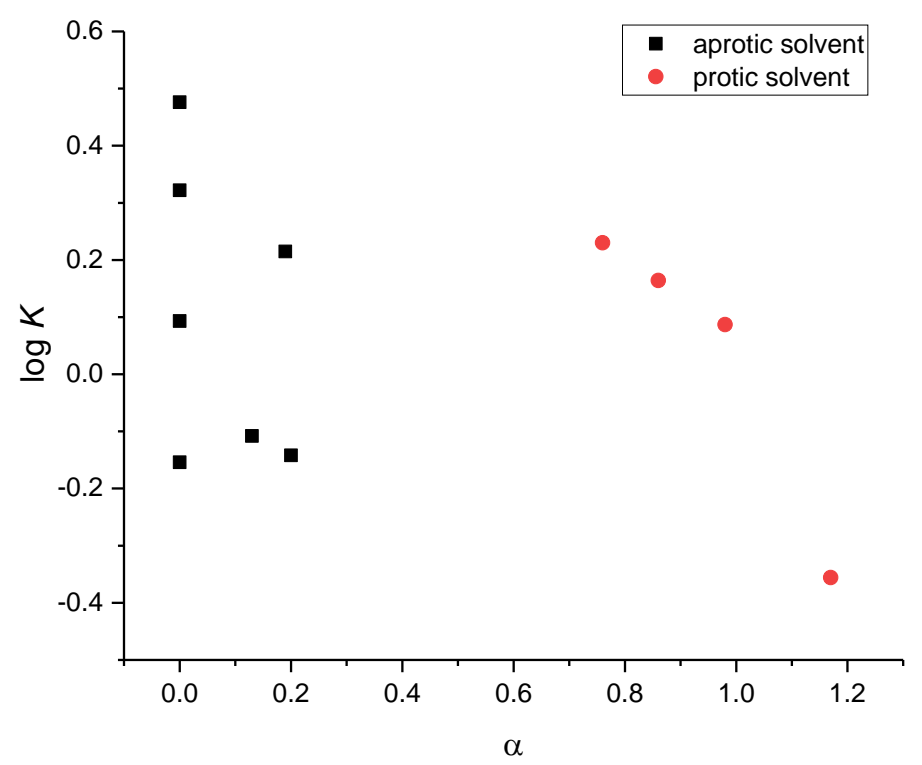

Figure S65. Plot of $\log K$ of imine exchange in varied solvents versus Taft parameter $\alpha$. 


\section{(2) Solvent effect on kinetics}

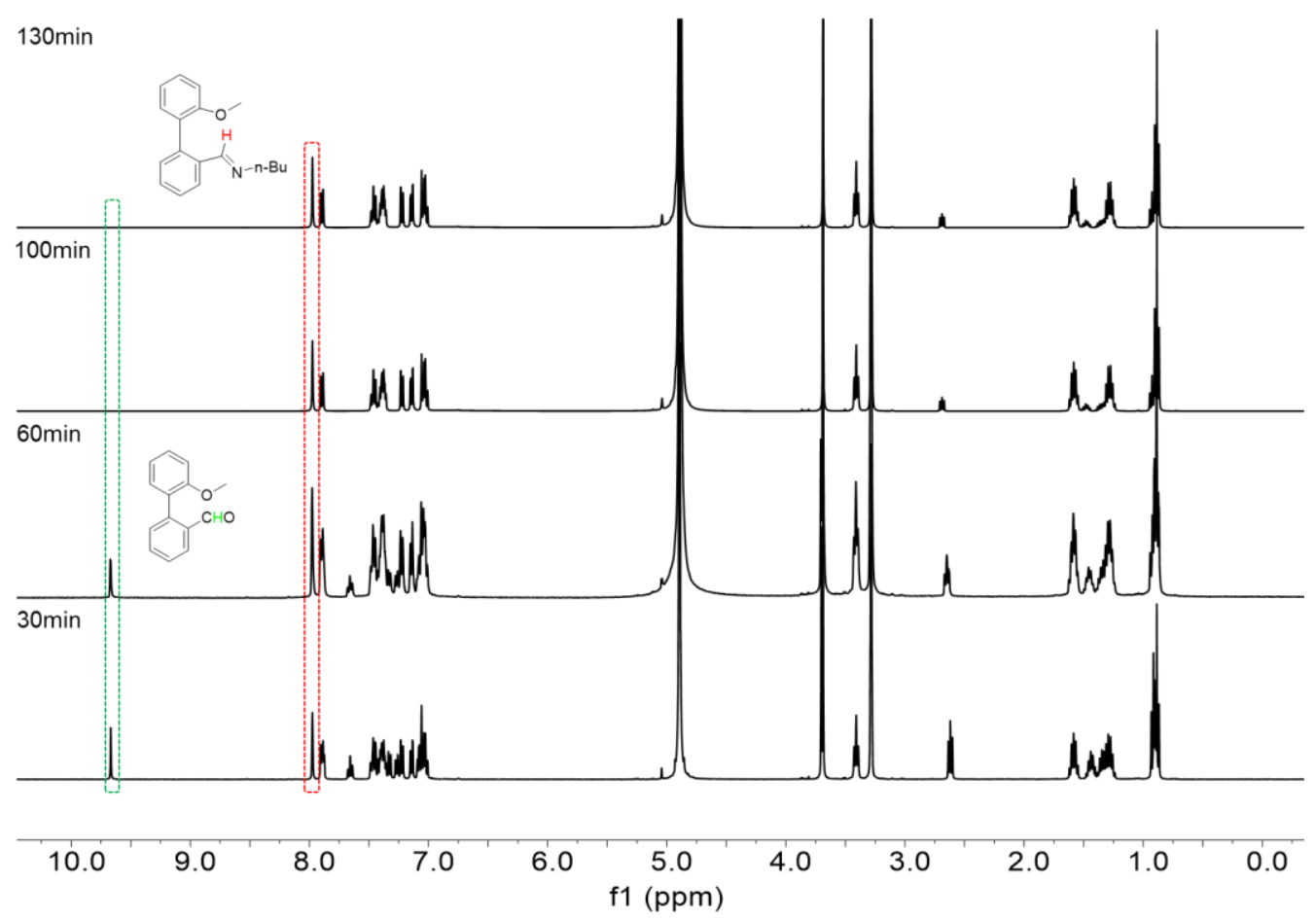

Figure S66. ${ }^{1} \mathrm{H}$ NMR spectra of the reaction between $1(\mathrm{OMe})(20 \mathrm{mM}, 1.0$ equiv.) and 1-butylamine (24 mM, 1.2 equiv.) in $\mathrm{CD}_{3} \mathrm{OD}$. The reaction was complete in 100 $\min$.

Table S10. The equilibrium constant and equilibrating time of the imine exchange with different sequence of reagents addition in $\mathrm{CD}_{3} \mathrm{OD}$ or $\mathrm{D}_{2} \mathrm{O}$.

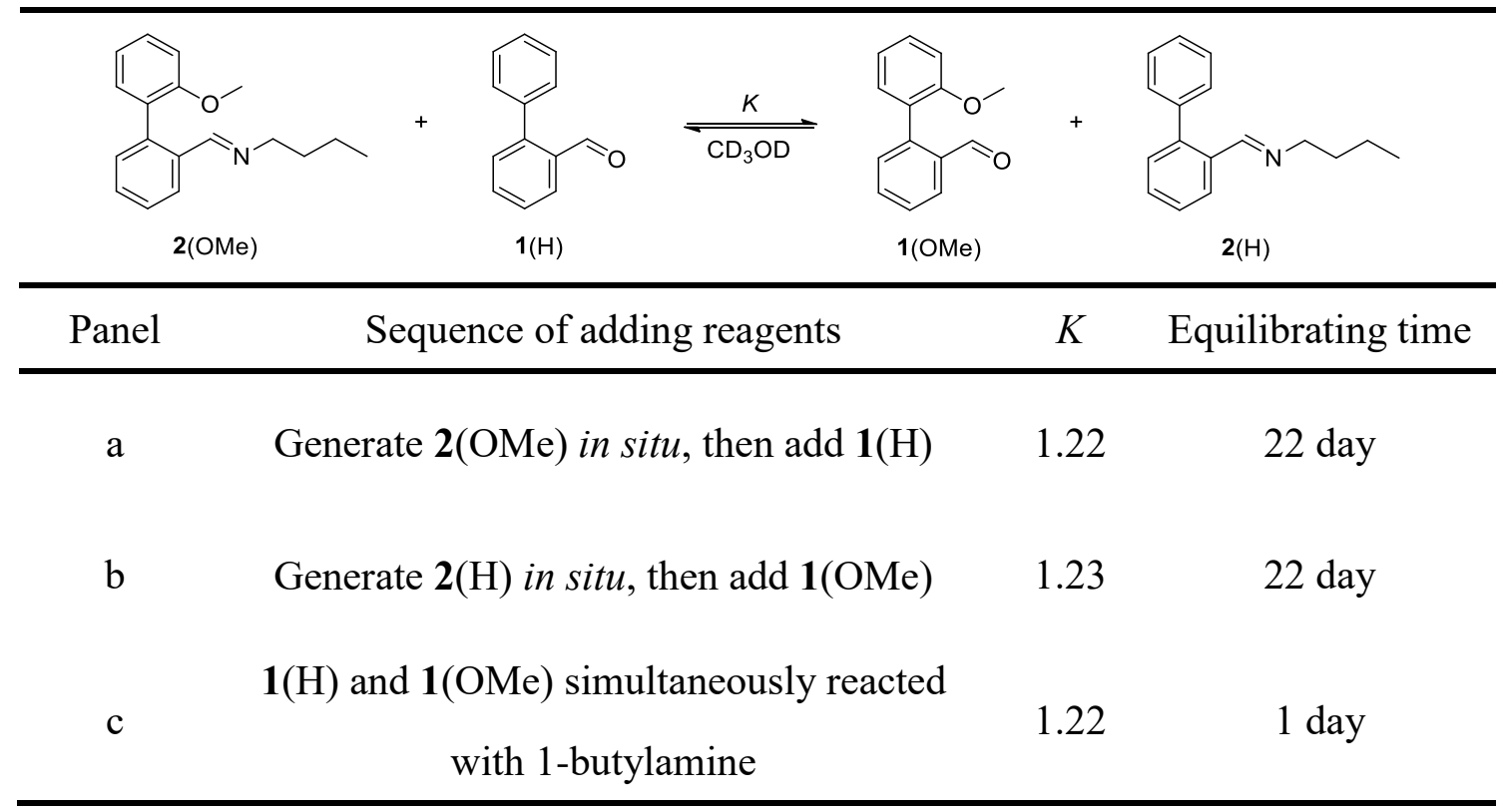




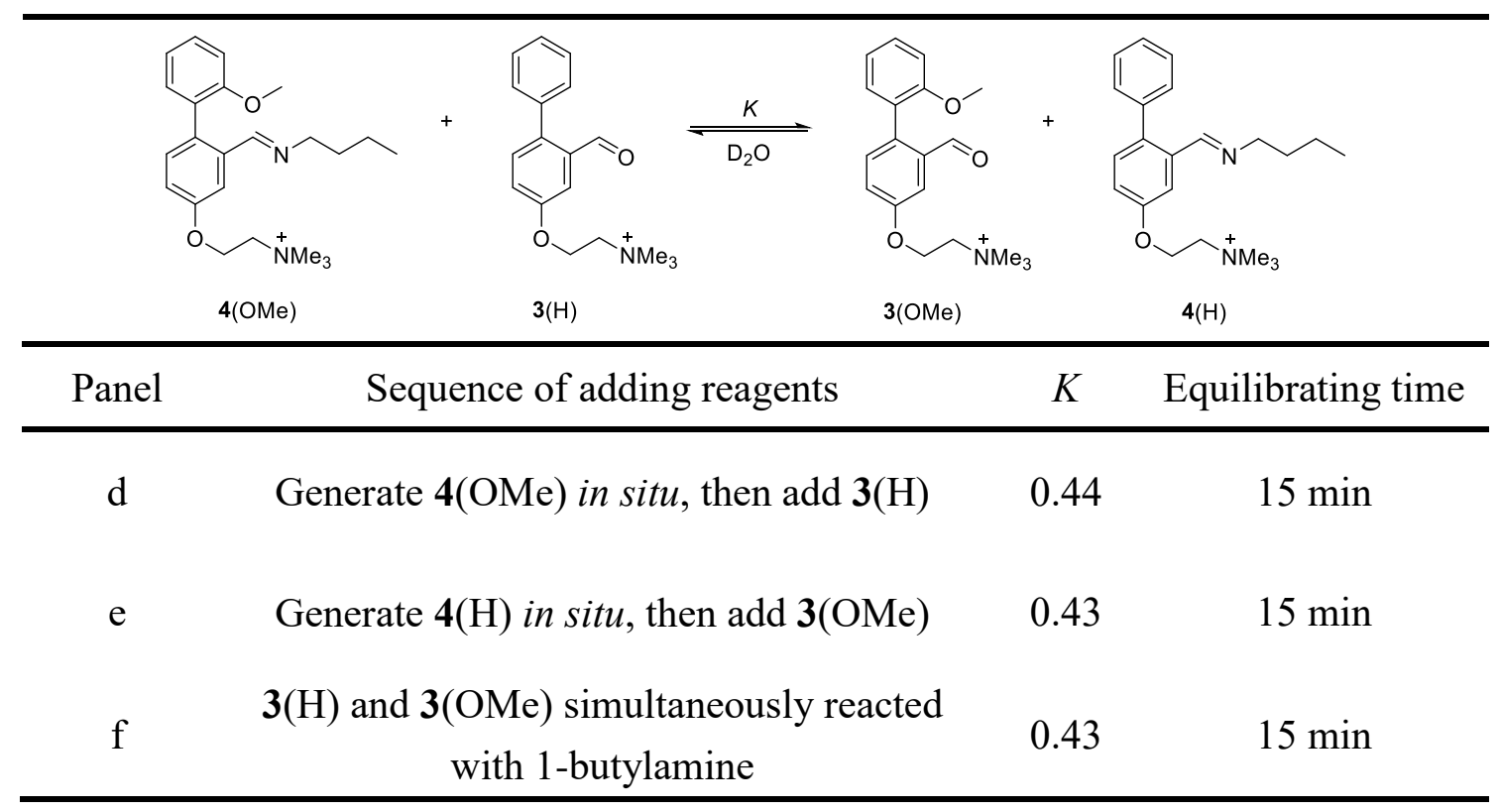

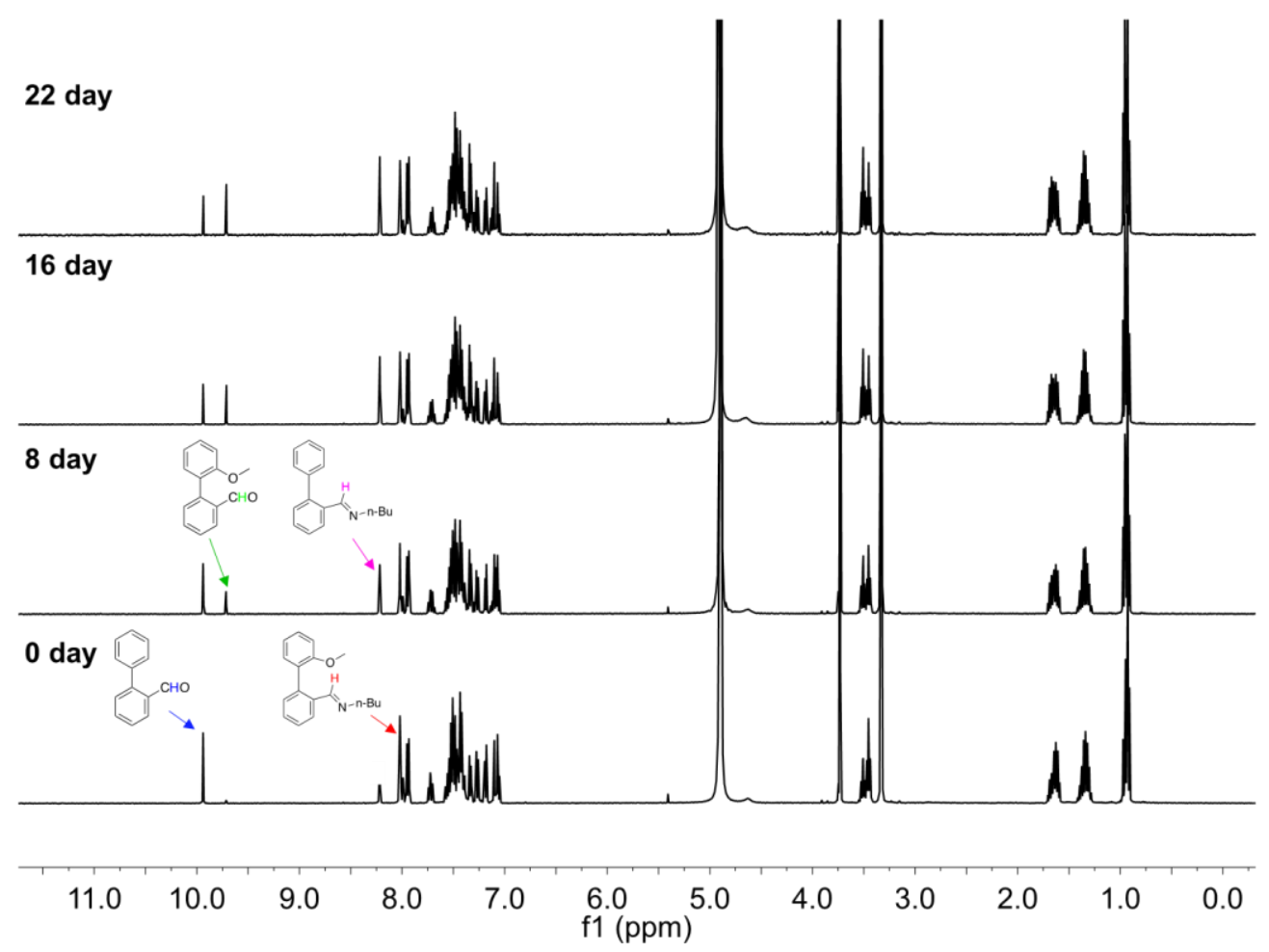

Figure S67. ${ }^{1} \mathrm{H}$ NMR spectra of the reaction of preformed $2(\mathrm{OMe})$ and $\mathbf{1}(\mathrm{H})$ in $\mathrm{CD}_{3} \mathrm{OD}$ at varied time (the corresponding spectra of panel a in Table S10). 
a

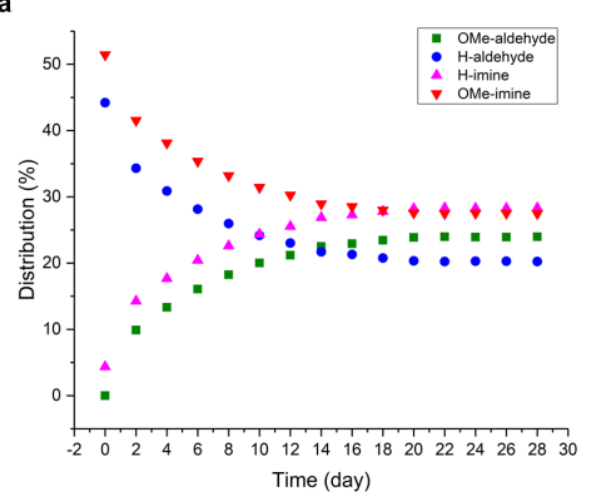

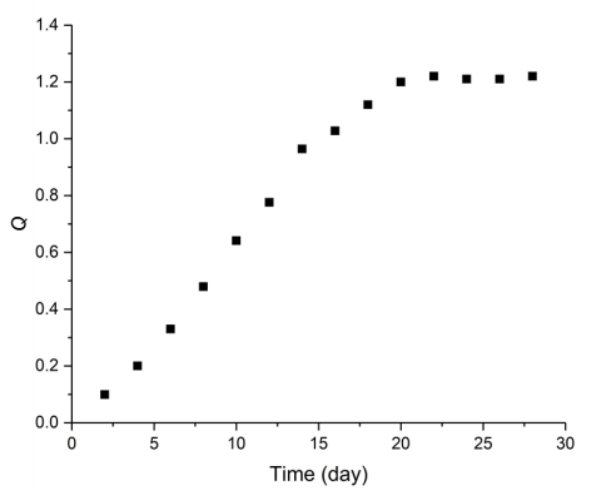

Figure S68. The kinetic profile of the reaction of preformed $2(\mathrm{OMe})$ and $\mathbf{1}(\mathrm{H})$ in $\mathrm{CD}_{3} \mathrm{OD}$ : (a) component distribution; (b) reaction quotient $(Q)$.

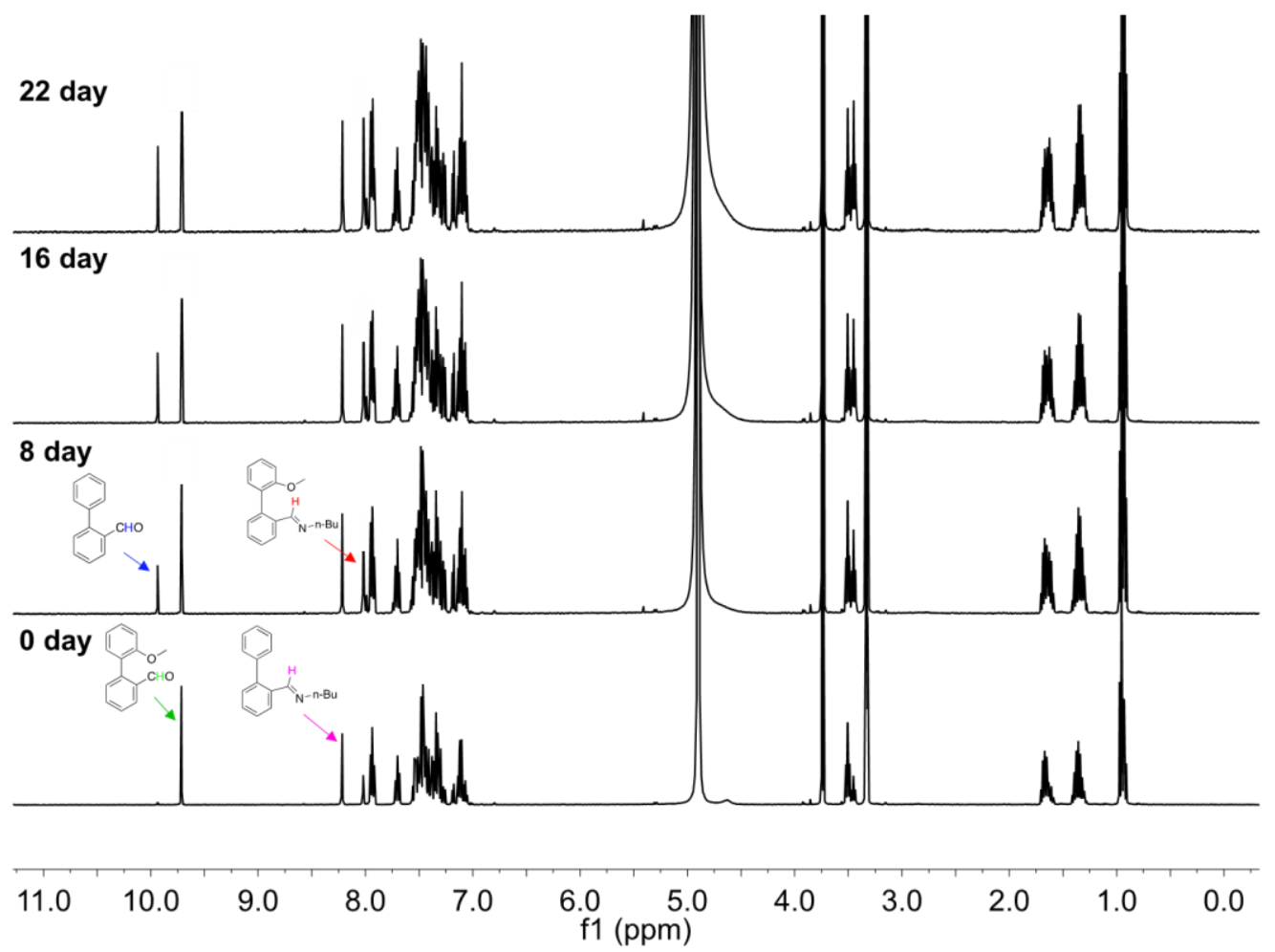

Figure S69. ${ }^{1} \mathrm{H}$ NMR spectra of the reaction of preformed $2(\mathrm{H})$ and $\mathbf{1}(\mathrm{OMe})$ in $\mathrm{CD}_{3} \mathrm{OD}$ at varied time (the corresponding spectra of panel $\mathrm{b}$ in Table S10). 
a

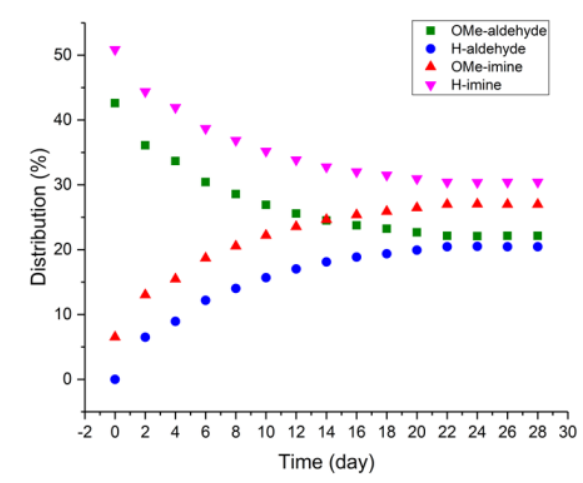

b

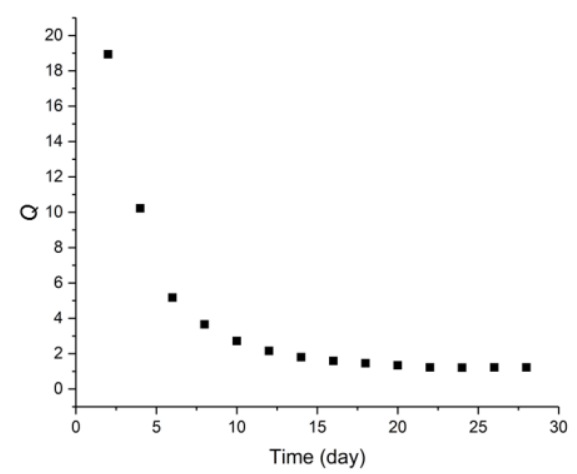

Figure S70. The kinetic profile of the reaction of preformed $2(\mathrm{H})$ and $\mathbf{1}(\mathrm{OMe})$ in $\mathrm{CD}_{3} \mathrm{OD}$ : (a) component distribution; (b) reaction quotient $(Q)$.

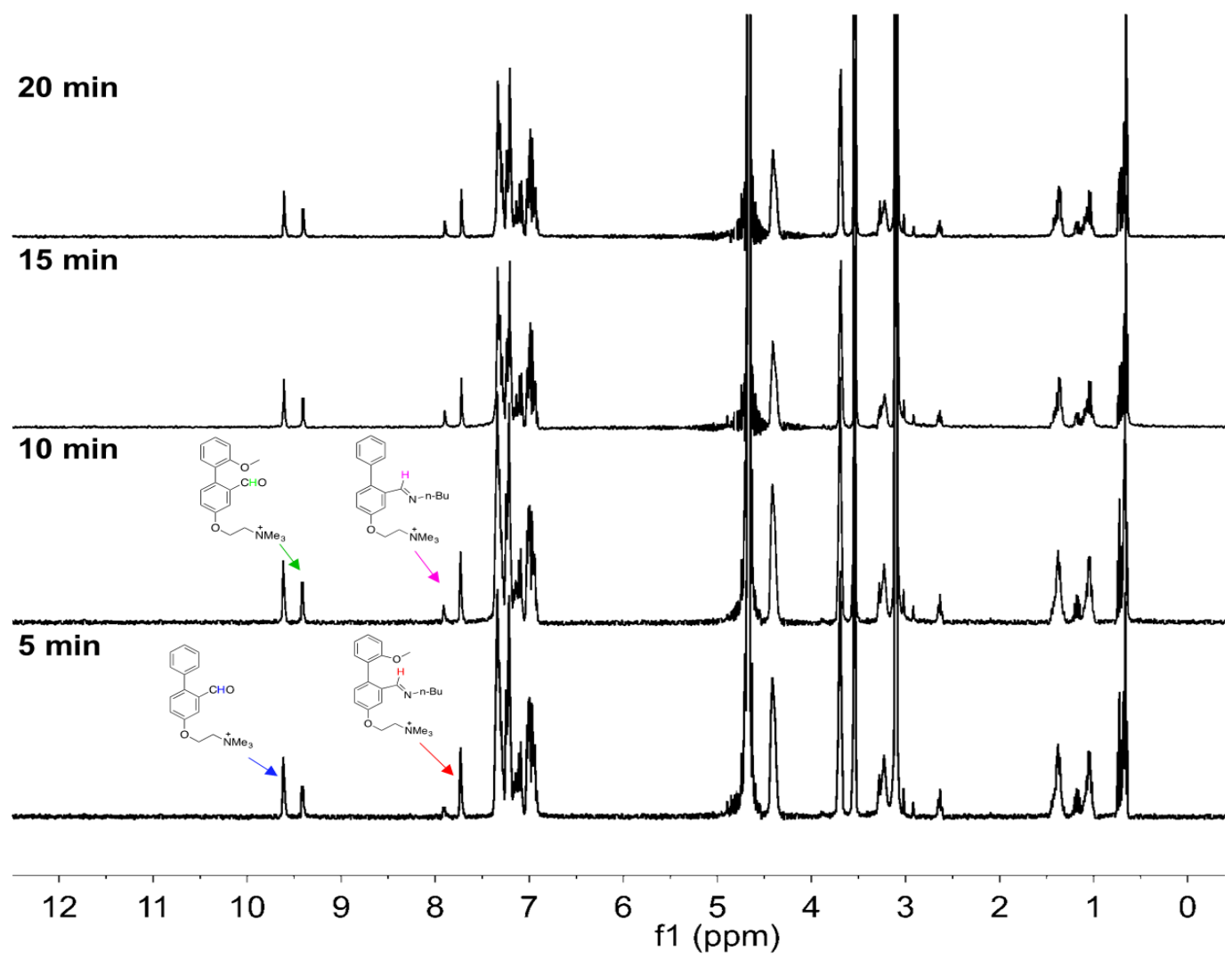

Figure S71. ${ }^{1} \mathrm{H}$ NMR spectra of the reaction of preformed $4(\mathrm{OMe})$ and $3(\mathrm{H})$ in $\mathrm{D}_{2} \mathrm{O}$ at varied time (the corresponding spectra of panel $\mathrm{d}$ in Table S10). 
a

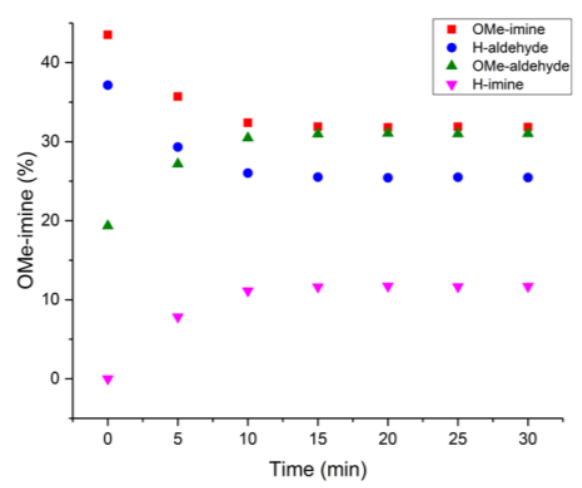

b

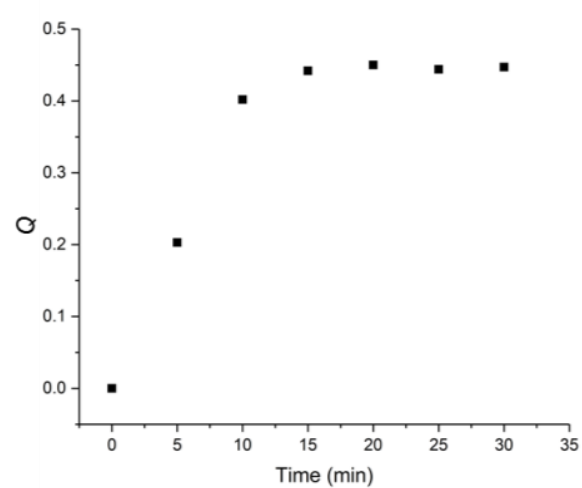

Figure S72. The kinetic profile of the reaction of preformed $4(\mathrm{OMe})$ and $\mathbf{3}(\mathrm{H})$ in $\mathrm{D}_{2} \mathrm{O}$ : (a) component distribution; (b) reaction quotient $(Q)$.

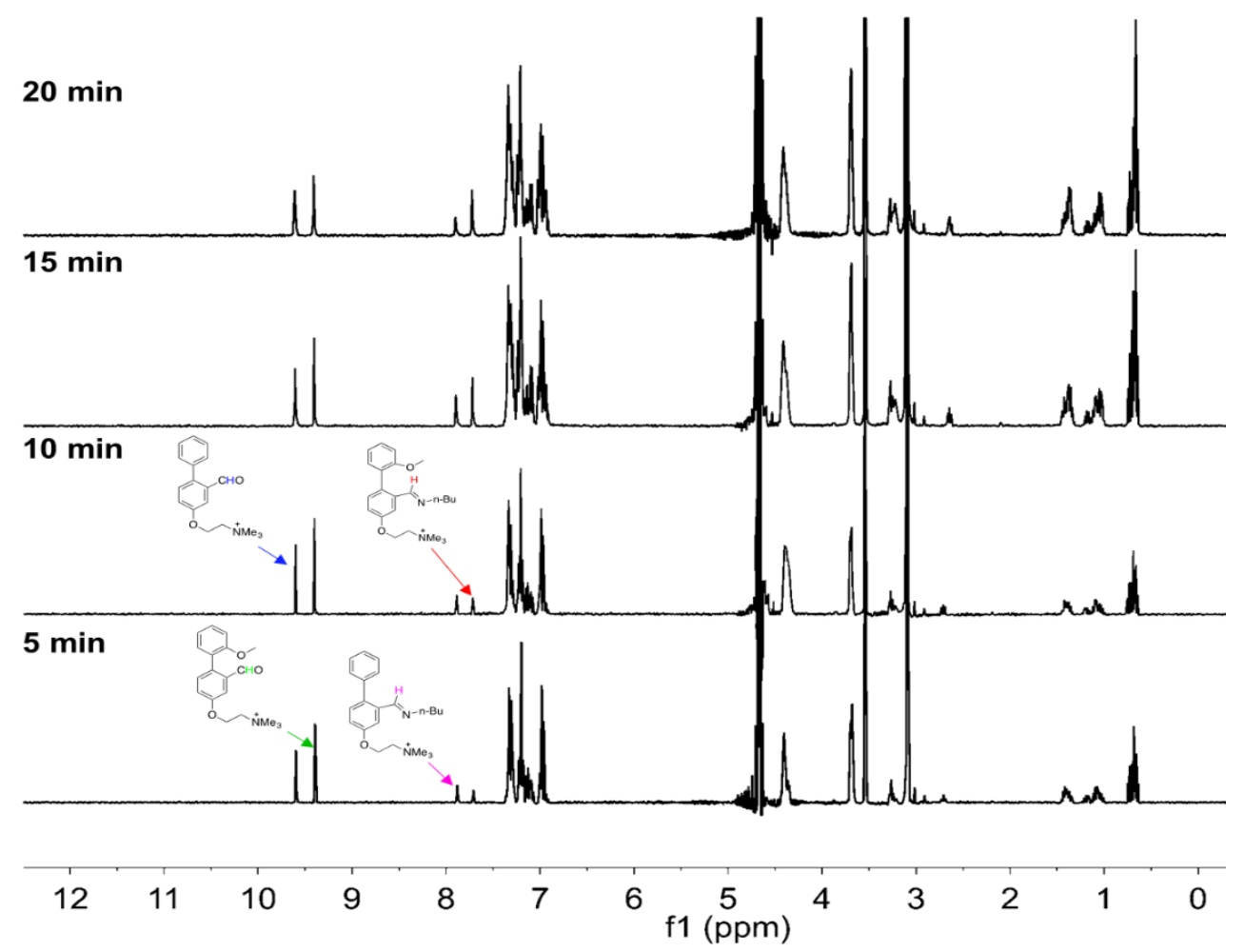

Figure S73. ${ }^{1} \mathrm{H}$ NMR spectra of the reaction of preformed $4(\mathrm{H})$ and $\mathbf{3}(\mathrm{OMe})$ in $\mathrm{D}_{2} \mathrm{O}$ at varied time (the corresponding spectra of panel e in Table S10). 

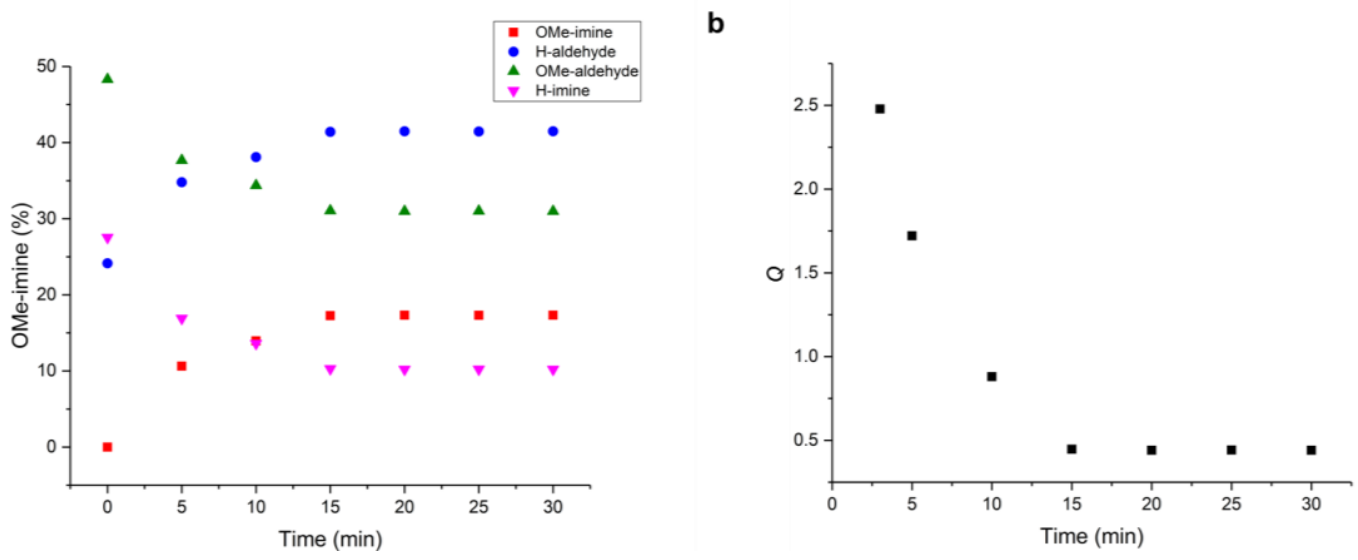

Figure S74. The kinetic profile of the reaction of preformed $4(\mathrm{H})$ and $\mathbf{3}(\mathrm{OMe})$ in $\mathrm{D}_{2} \mathrm{O}$ : (a) component distribution; (b) reaction quotient $(Q)$.

\section{(3) Solvent effect on $n \rightarrow \pi *$ interaction}

To explore the impact of protic solvents, one methanol molecule was added to reflect the weak interaction between the solvent and aldehyde, and this complex was subjected for computation in methanol (with PCM solvent model). The difference in free energies $(\triangle G)$ of conformers was summarized in Figure S75. The NBO stabilization energy $\left(\triangle \mathrm{E}^{(2)}\right)$ of $n \rightarrow \pi^{*}$ interaction and associated structure features are summarized in Table S11.
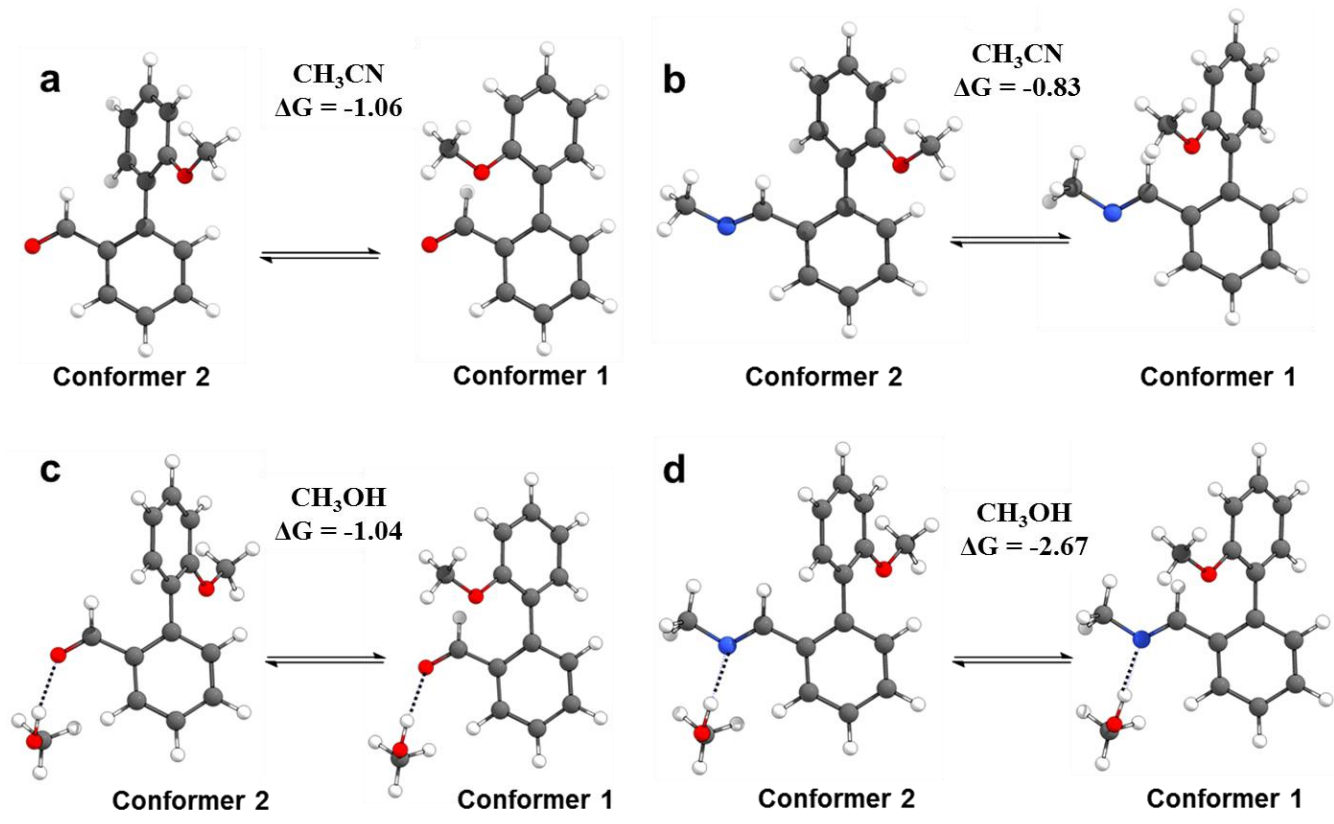

Figure S75. Calculated structures and free energy difference (kcal/mol) for 
conformational equilibrium of $\mathbf{1}(\mathrm{OMe})$ and $2(\mathrm{OMe})$ in acetonitrile and methanol, respectively. Based on Boltzmann distribution of conformers, $\triangle \mathrm{G}$ of the exchange reaction (Figure 4A) was found to be -0.251 and $-0.103 \mathrm{kcal} / \mathrm{mol}$ in acetonitrile and methanol, respectively. The trend is in agreement with measured $\triangle \mathrm{G}$ of -0.293 ( $K=$ 1.64) and $-0.118(K=1.22) \mathrm{kcal} / \mathrm{mol}$ in acetonitrile and methanol, respectively (Figure 4B and Table S9).

Table S11. The comparison of $n \rightarrow \pi^{*}$ interaction $\left(\triangle \mathrm{E}^{(2)}\right)$ and structural parameters of conformer 1 for $\mathbf{1}(\mathrm{OMe})$ and $\mathbf{2}(\mathrm{OMe})$ in acetonitrile and methanol, respectively.

\begin{tabular}{|c|c|c|}
\hline \multicolumn{3}{|c|}{$\begin{array}{l}\text { Calculated structures of } \mathbf{1}(\mathrm{OMe}) \text { in } \\
\qquad \mathrm{CH}_{3} \mathrm{CN} \text { or } \mathrm{CH}_{3} \mathrm{OH}\end{array}$} \\
\hline & Conformer $1\left(\mathrm{CH}_{3} \mathrm{CN}\right)$ & Conformer $1\left(\mathrm{CH}_{3} \mathrm{OH}\right)$ \\
\hline$\triangle \mathrm{E}^{(2)}(\mathrm{kcal} / \mathrm{mol})$ & -1.74 & -1.81 \\
\hline$\alpha(2-3-4-5)\left({ }^{\circ}\right)$ & 54.3 & 54.3 \\
\hline$\beta(4-5-6-7)\left(^{\circ}\right)$ & 14.4 & 13.1 \\
\hline $\mathrm{D}(1-6)(\AA)$ & 2.78 & 2.77 \\
\hline $\mathrm{D}(6-8)(\AA)$ & 1.21 & 1.21 \\
\hline $\mathrm{D}(8-9)(\AA)$ & None & 1.91 \\
\hline \multicolumn{3}{|c|}{$\begin{array}{l}\text { Calculated structures of } 2(\mathrm{OMe}) \text { in } \\
\qquad \mathrm{CH}_{3} \mathrm{CN} \text { or } \mathrm{CH}_{3} \mathrm{OH}\end{array}$} \\
\hline & Conformer $1\left(\mathrm{CH}_{3} \mathrm{CN}\right)$ & Conformer $1\left(\mathrm{CH}_{3} \mathrm{OH}\right)$ \\
\hline$\Delta \mathrm{E}^{(2)}(\mathrm{kcal} / \mathrm{mol})$ & -1.21 & -2.34 \\
\hline$\alpha(2-3-4-5)\left({ }^{\circ}\right)$ & 57.5 & 46.1 \\
\hline$\beta(4-5-6-7)\left(\left(^{\circ}\right)\right.$ & 15.0 & 21.0 \\
\hline $\mathrm{D}(1-6)(\AA)$ & 2.86 & 2.69 \\
\hline $\mathrm{D}(6-8)(\AA)$ & 1.26 & 1.26 \\
\hline $\mathrm{D}(8-9)(\AA)$ & None & 1.86 \\
\hline
\end{tabular}




\section{Imine Formation in Aqueous Phase}

Imine formation in aqueous phase was performed in situ without isolation and purification. To a solution of 3 or $5\left(20 \mathrm{mM}, 1.0\right.$ equiv.) in $\mathrm{D}_{2} \mathrm{O}(0.60 \mathrm{~mL})$, was added the amine (22 mM, 1.2 equiv.). The mixture was characterized by ${ }^{1} \mathrm{H}$ NMR and ESI-MS after the equilibrium was reached.

For imine formation in $\mathrm{D}_{2} \mathrm{O}$ buffer solution, 3 (20 mM, 10.0 equiv.) were dissolved in $600 \mu \mathrm{L} \mathrm{KPi}$ buffer in $\mathrm{D}_{2} \mathrm{O}(20 \mathrm{mM}, \mathrm{pH}=7.8)$, and a buffer solution of amine (1.09 M, $\mathrm{pH}=7.8: 1.1 \mu \mathrm{L}, 1.0$ equiv.; the final concentration of amine was $2 \mathrm{mM}$ ) was next added. The mixture was characterized by ${ }^{1} \mathrm{H}$ NMR and ESI-MS.

For imine formation in buffer solution, $3(0.20 \mathrm{mM}, 100$ equiv.) were dissolved in 600 $\mu \mathrm{L} \mathrm{KPi}$ buffer $(20 \mathrm{mM}, \mathrm{pH}=7.4)$, and a buffer solution of amine $(1.2 \mathrm{mM}, \mathrm{pH}=7.4$ : $1.0 \mu \mathrm{L}, 1.0$ equiv.; the final concentration of amine was $2 \mu \mathrm{M}$ ) was next added. The mixture was characterized by ESI-MS.

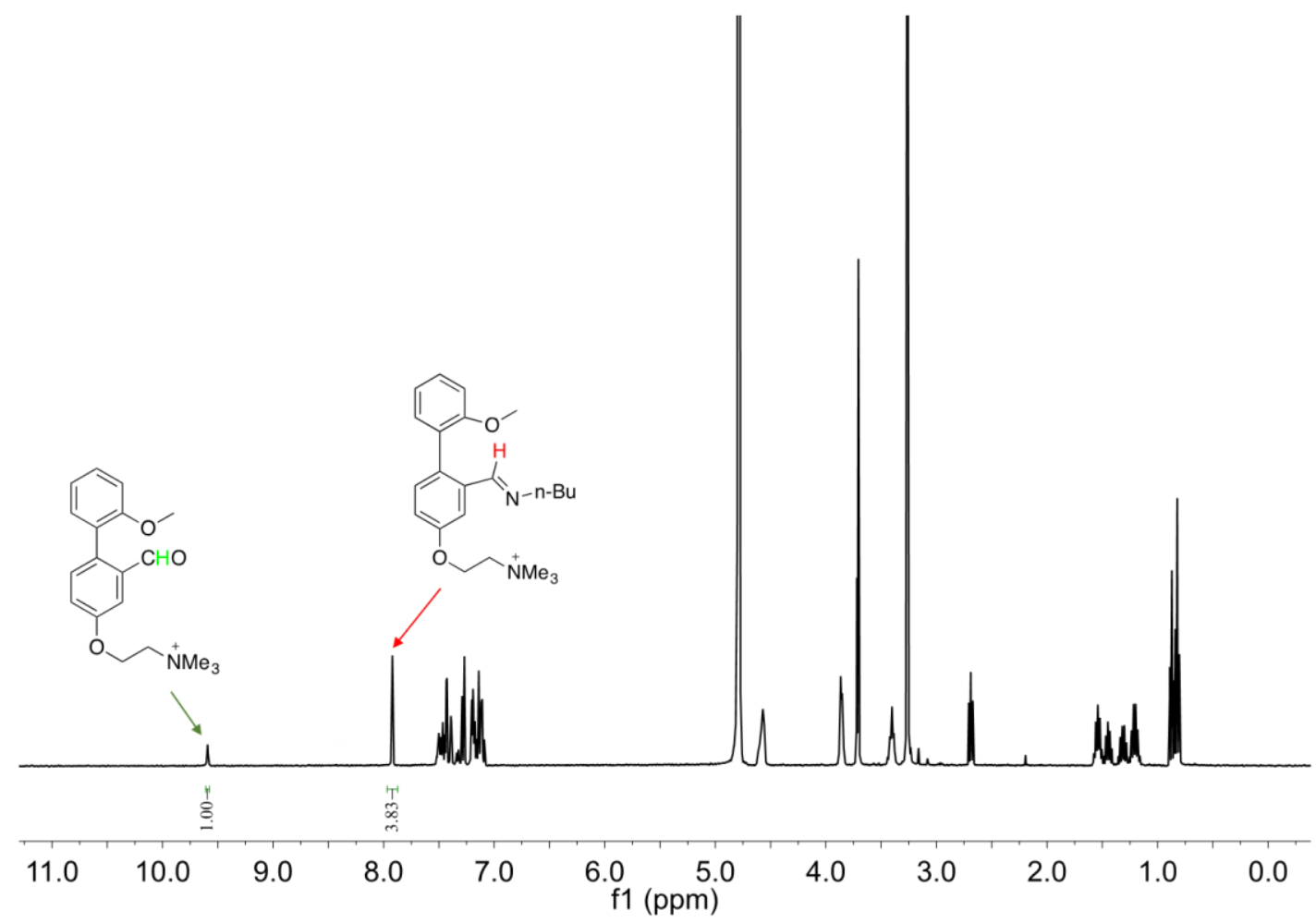

Figure S76. ${ }^{1} \mathrm{H}$ NMR spectrum of the reaction of $\mathbf{3}(\mathrm{OMe})(20 \mathrm{mM}, 1.0$ equiv. $)$ and 1-butylamine (24 mM, 1.2 equiv.) in $\mathrm{D}_{2} \mathrm{O}$. The yield of imine is $79 \%$. 


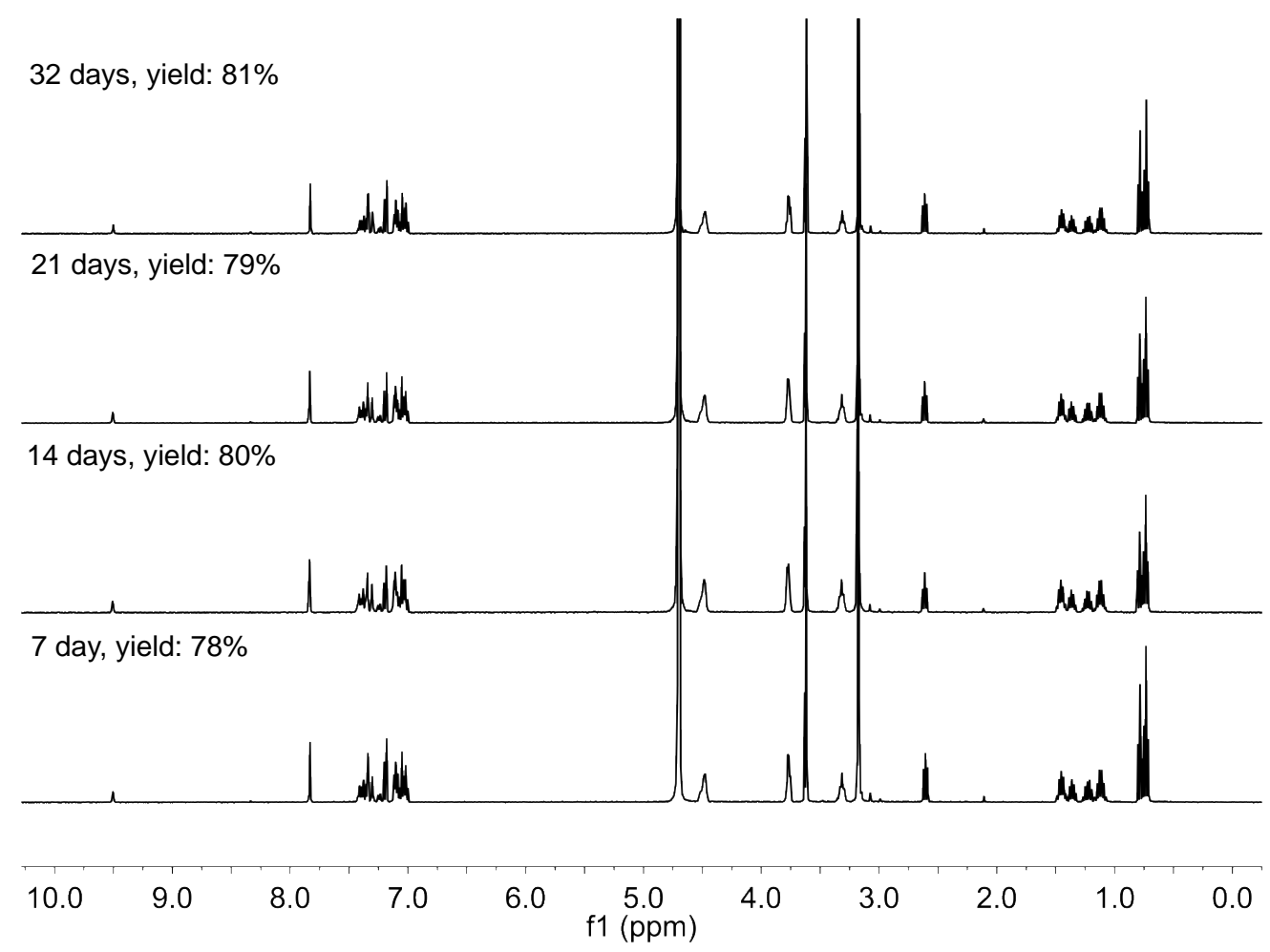

Figure S77. ${ }^{1} \mathrm{H}$ NMR spectra of the reaction of $\mathbf{3}(\mathrm{OMe})(20 \mathrm{mM}, 1.0$ equiv. $)$ and 1-butylamine (1.2 equiv.) in $\mathrm{D}_{2} \mathrm{O}$ at varied time. No decomposition of imine occurred.

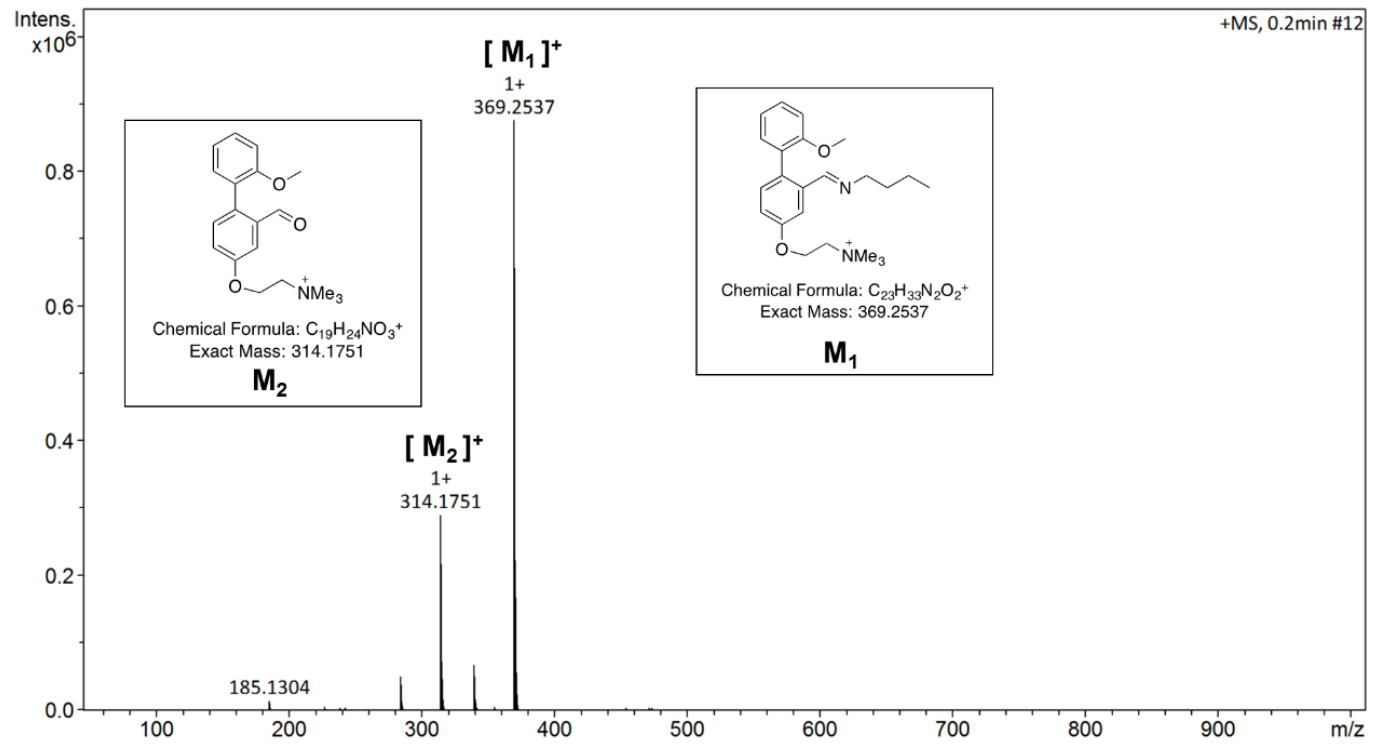

Figure S78. ESI-MS spectrum of the reaction of $\mathbf{3}(\mathrm{OMe})(20 \mathrm{mM}, 1.0$ equiv.) and 1-butylamine (1.2 equiv.) in $\mathrm{D}_{2} \mathrm{O}$. 


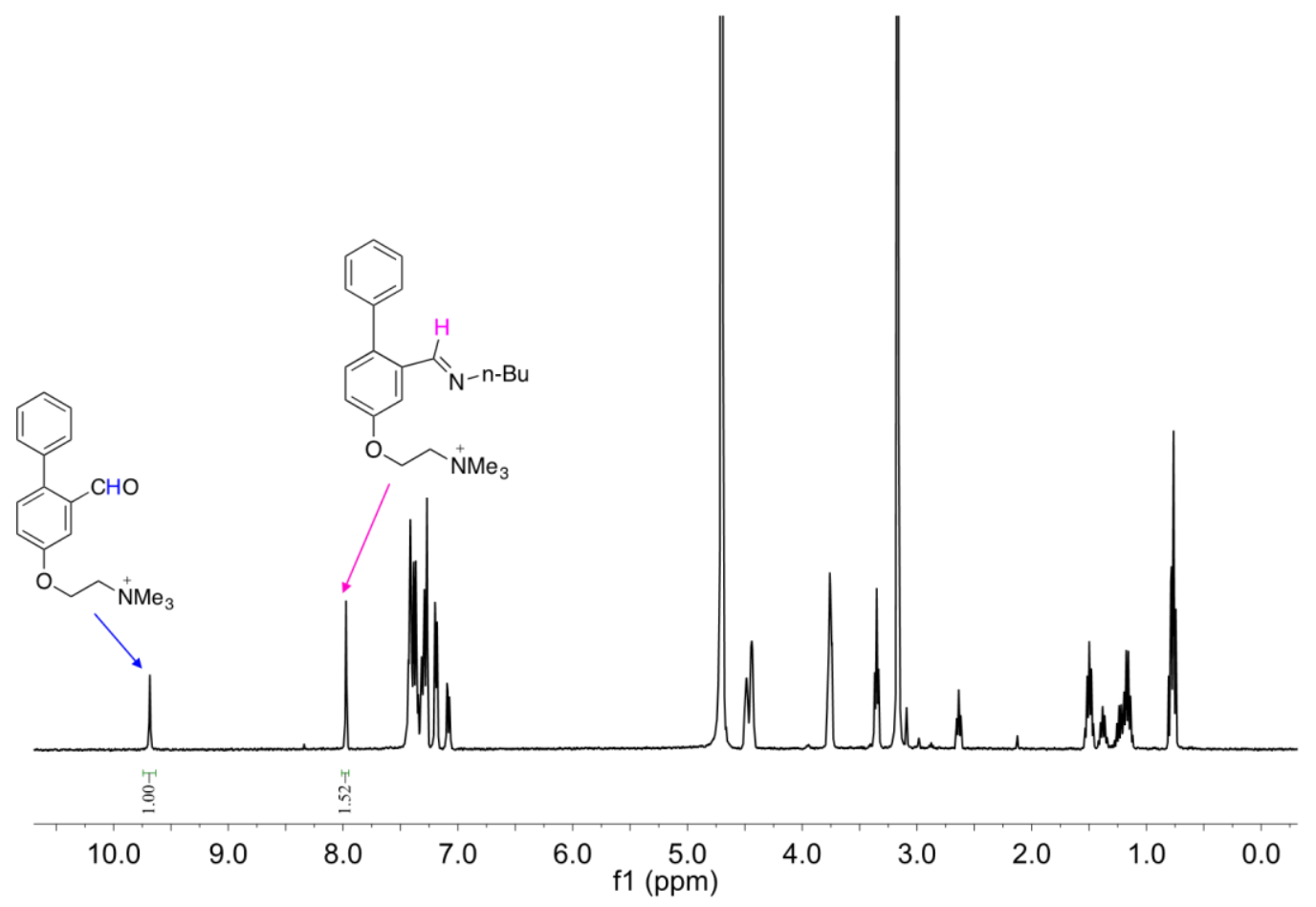

Figure S79. ${ }^{1} \mathrm{H}$ NMR spectrum of the reaction of $3(\mathrm{H})(20 \mathrm{mM}, 1.0$ equiv.) and 1-butylamine (1.2 equiv.) in $\mathrm{D}_{2} \mathrm{O}$. The yield of imine is $60 \%$.

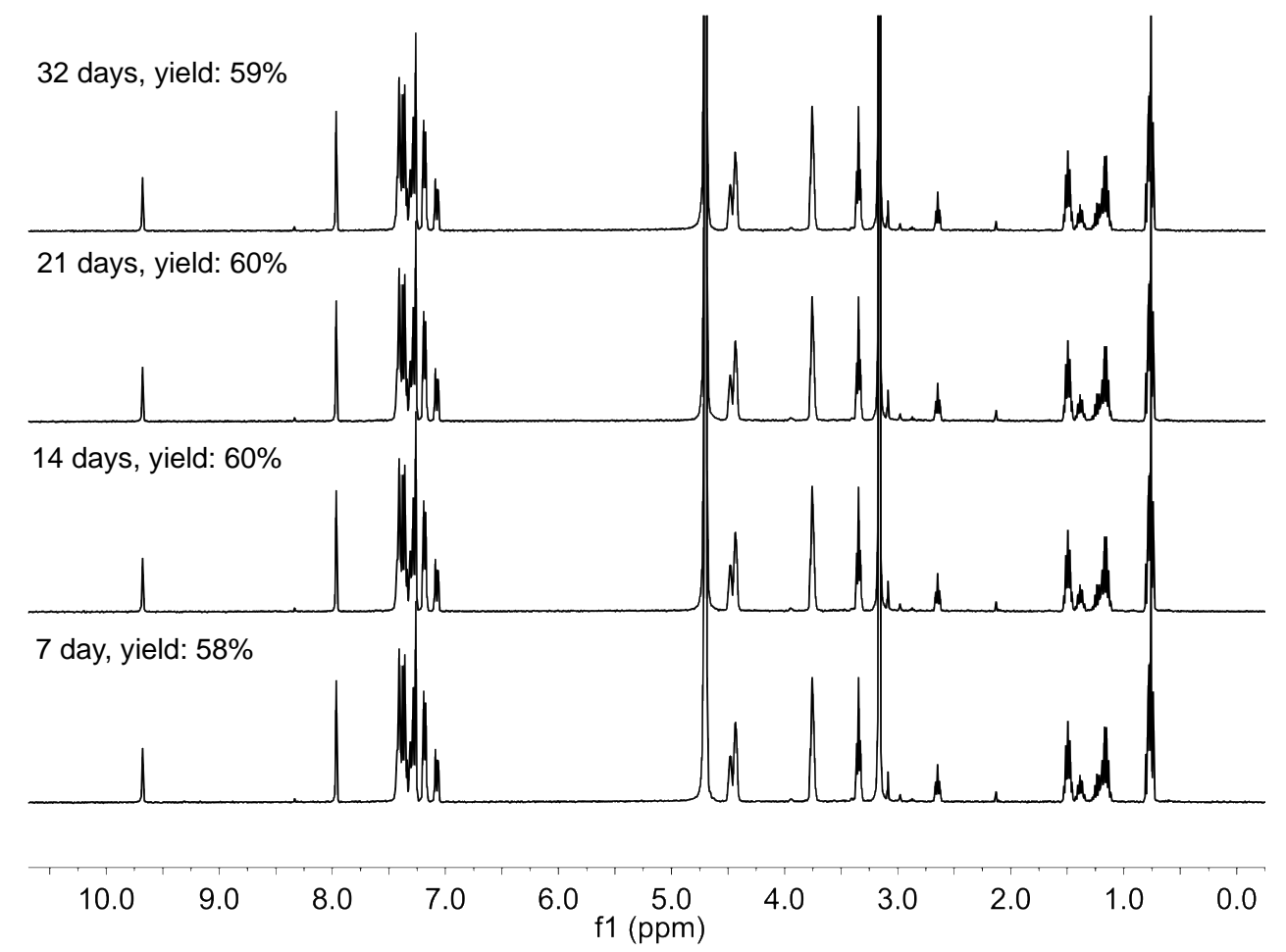

Figure 80. ${ }^{1} \mathrm{H}$ NMR spectra of the reaction of $\mathbf{3}(\mathrm{H})(20 \mathrm{mM}, 1.0$ equiv.) and 1-butylamine (1.2 equiv.) in $\mathrm{D}_{2} \mathrm{O}$ at varied time. No decomposition of imine occurred. 


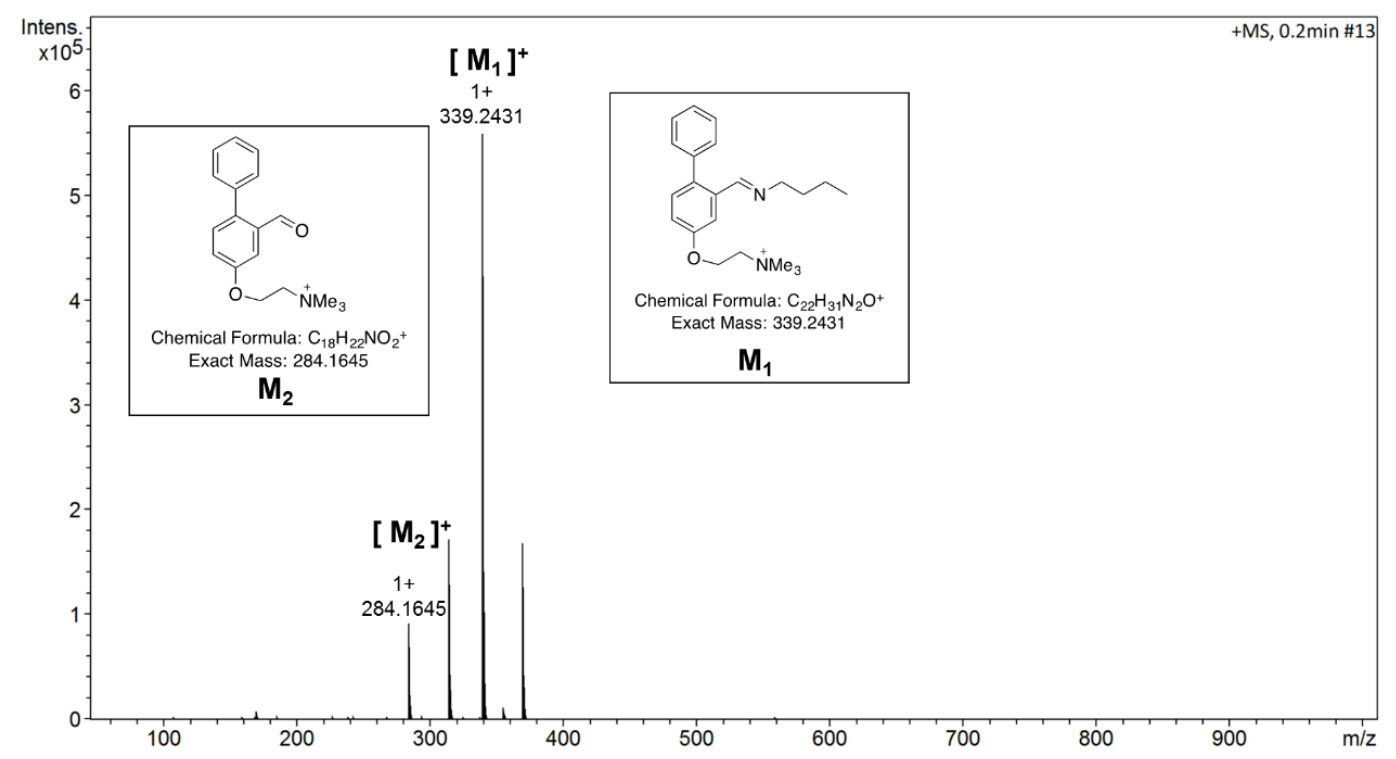

Figure S81. ESI-MS spectrum of the reaction of $\mathbf{3}(\mathrm{H})(20 \mathrm{mM}, 1.0$ equiv. $)$ and 1-butylamine (1.2 equiv.) in $\mathrm{D}_{2} \mathrm{O}$.

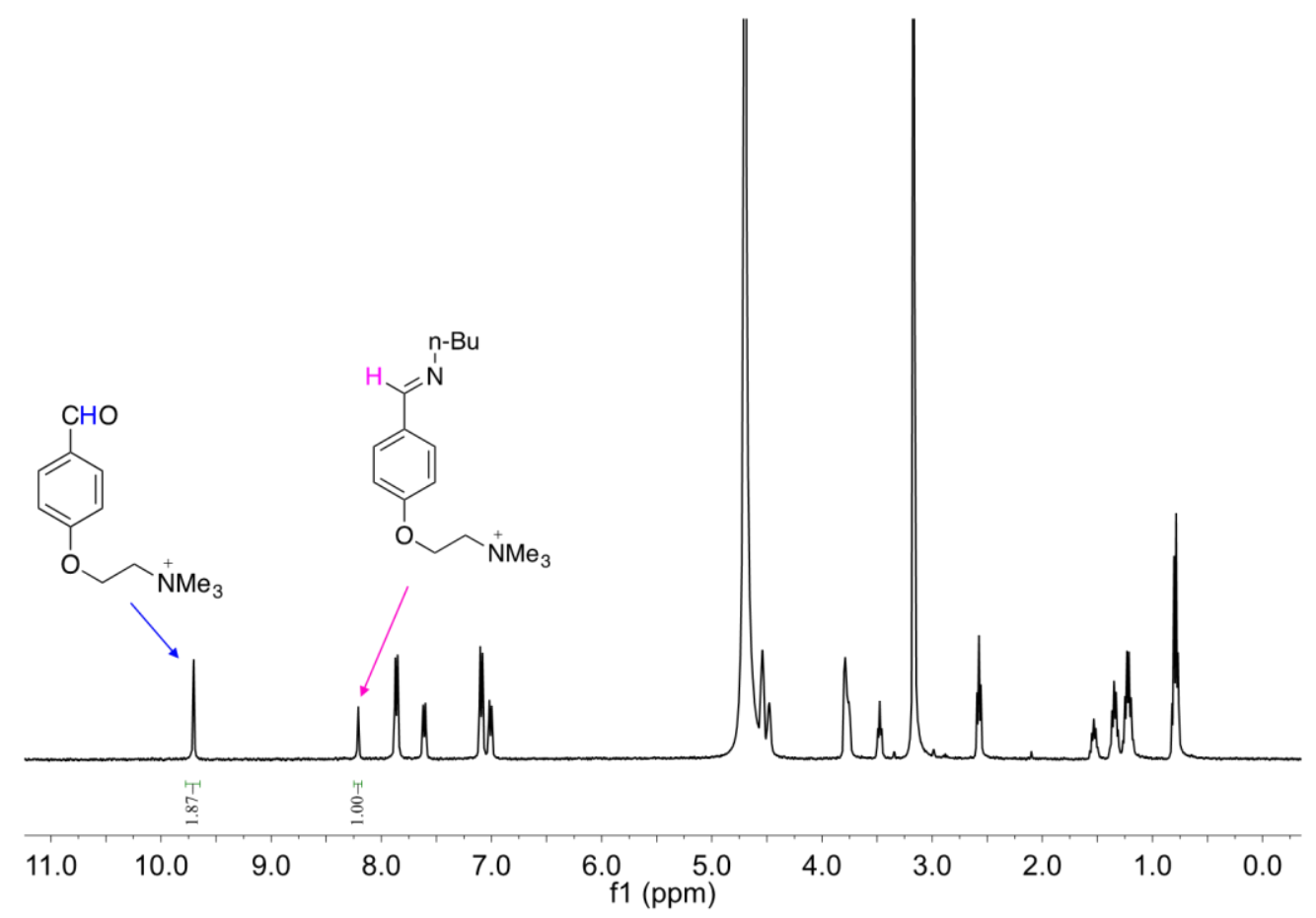

Figure S82. ${ }^{1} \mathrm{H}$ NMR spectrum of the reaction of $5(20 \mathrm{mM}, 1.0$ equiv.) and 1-butylamine (1.2 equiv.) in $\mathrm{D}_{2} \mathrm{O}$. The yield of imine is $35 \%$. 


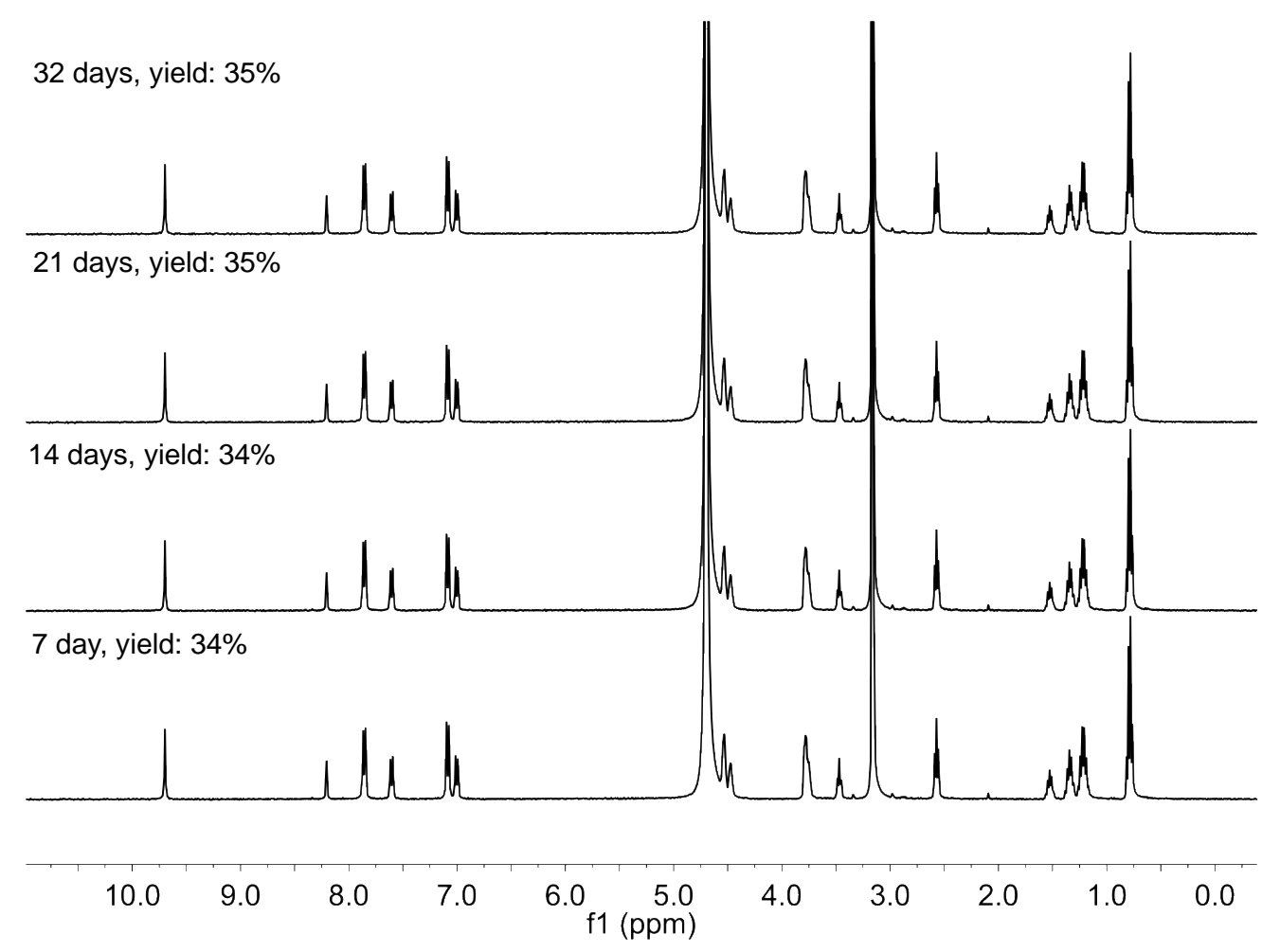

Figure S83. ${ }^{1} \mathrm{H}$ NMR spectra of the reaction of 5 (20 mM, 1.0 equiv.) and 1-butylamine (1.2 equiv.) in $\mathrm{D}_{2} \mathrm{O}$ at varied time. No decomposition of imine occurred.

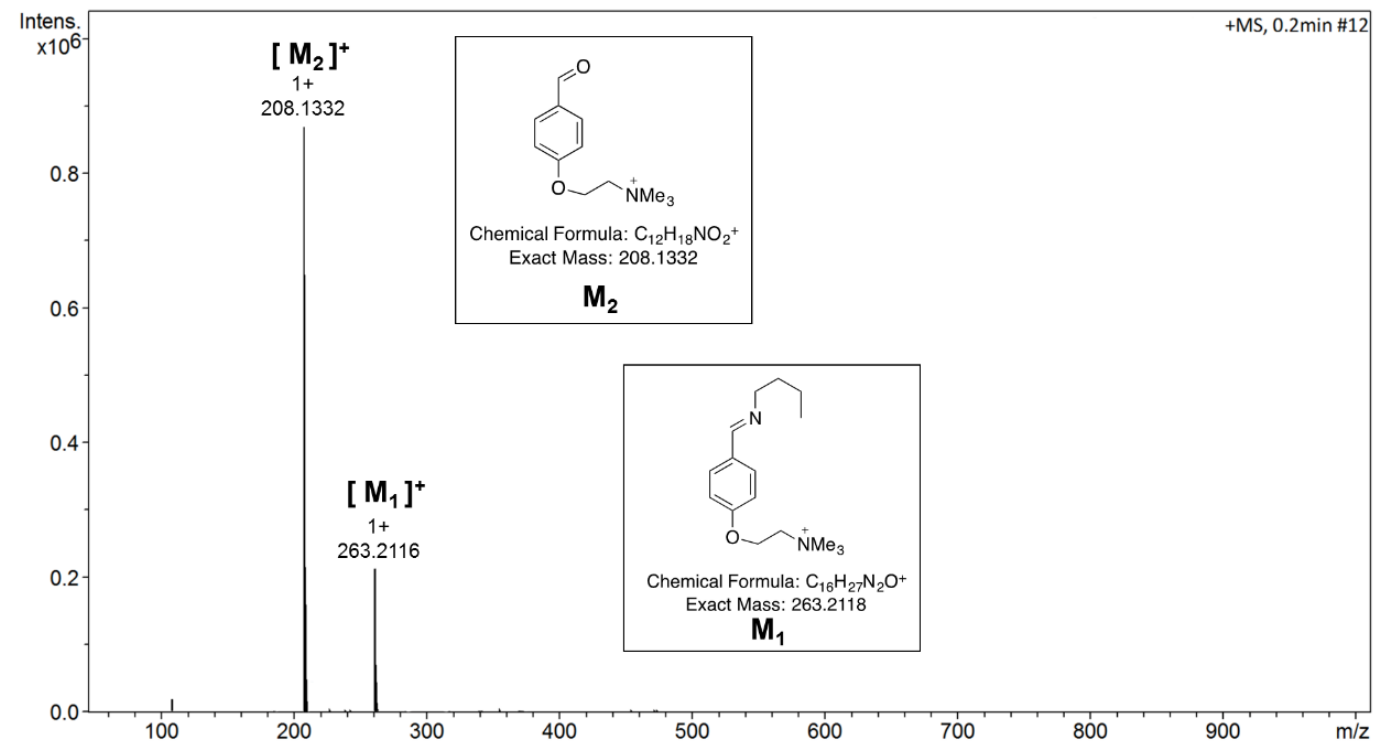

Figure S84. ESI-MS spectrum of the reaction of $5(20 \mathrm{mM}, 1.0$ equiv.) and 1-butylamine (1.2 equiv.) in $\mathrm{D}_{2} \mathrm{O}$. 


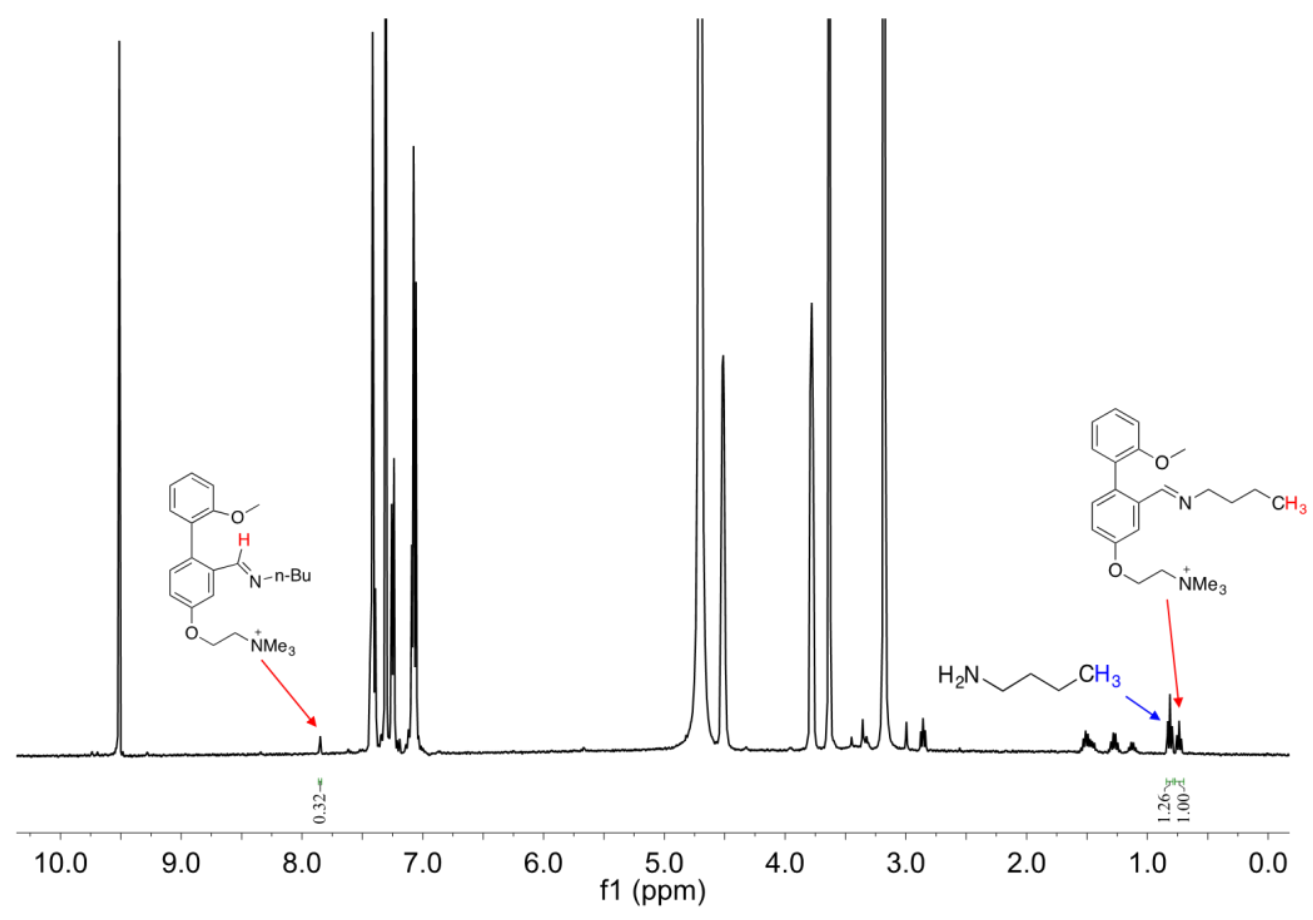

Figure S85. ${ }^{1} \mathrm{H}$ NMR spectrum of the reaction of $\mathbf{3}(\mathrm{OMe})(20 \mathrm{mM}, 10.0$ equiv. $)$ and 1-butylamine (2 mM, 1.0 equiv.) in $\mathrm{KPi}$ buffer solution in $\mathrm{D}_{2} \mathrm{O}(20 \mathrm{mM}, \mathrm{pH}=7.8)$. The yield of imine is $44 \%$.

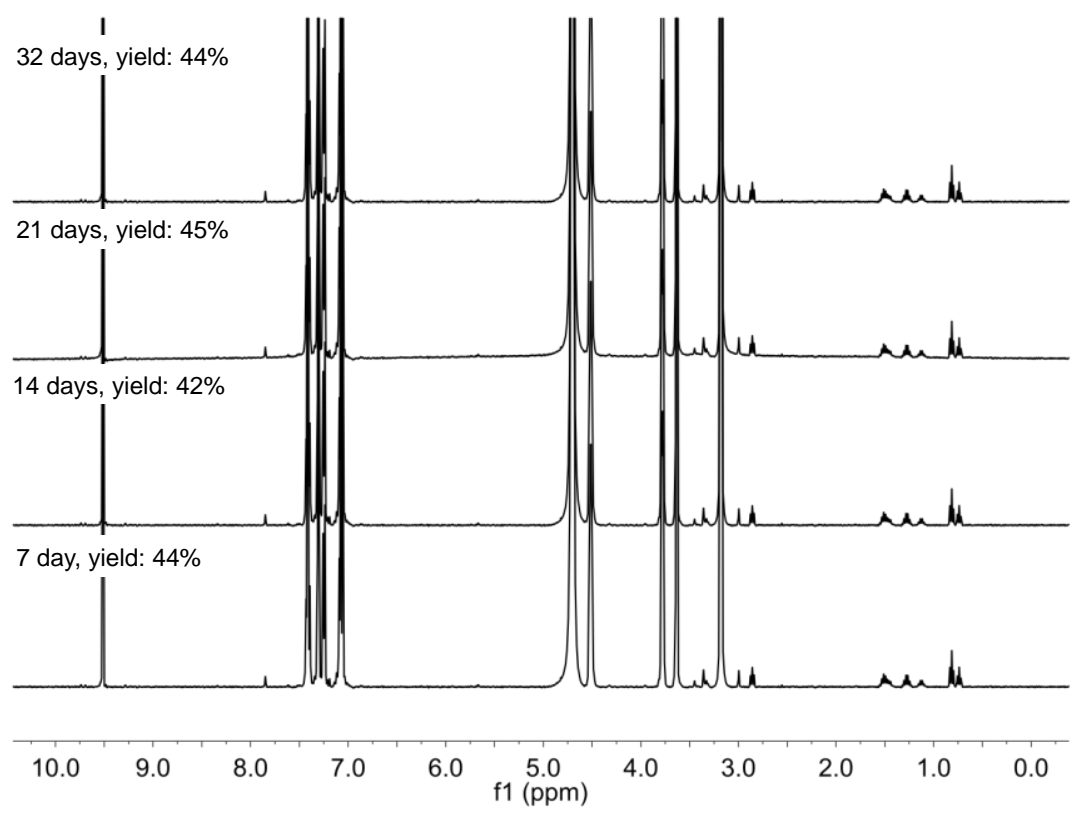

Figure S86. ${ }^{1} \mathrm{H}$ NMR spectra of the reaction of $3(\mathrm{OMe})(20 \mathrm{mM}, 10.0$ equiv.) and 1-butylamine (2 mM, 1.0 equiv.) in $\mathrm{KPi}$ buffer solution in $\mathrm{D}_{2} \mathrm{O}(20 \mathrm{mM}, \mathrm{pH}=7.8)$ at varied time. No decomposition of imine occurred. 


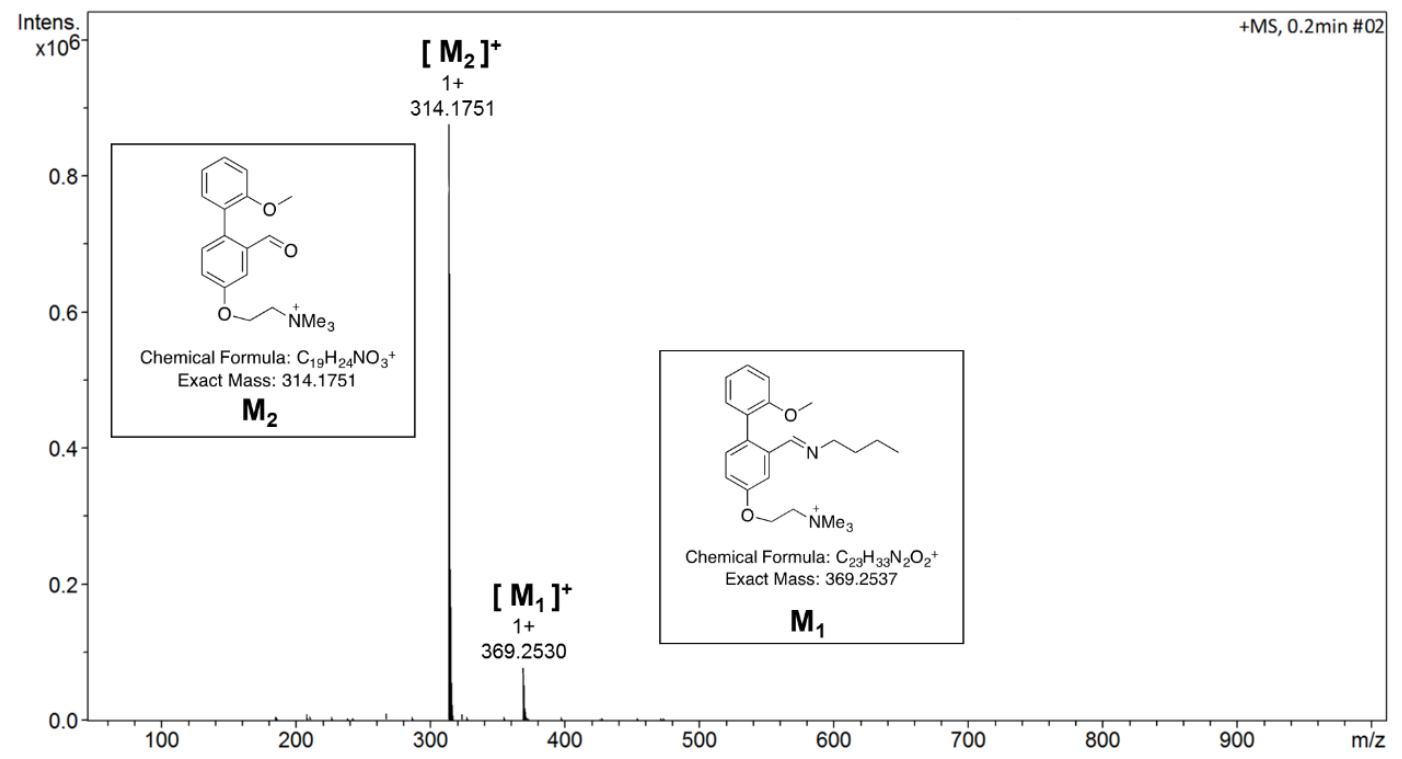

Figure S87. ESI-MS spectrum of the reaction of $\mathbf{3}(\mathrm{OMe})(20 \mathrm{mM}, 10.0$ equiv.) and 1-butylamine (2 mM, 1.0 equiv.) in KPi buffer solution in $\mathrm{D}_{2} \mathrm{O}(20 \mathrm{mM}, \mathrm{pH}=7.8)$.

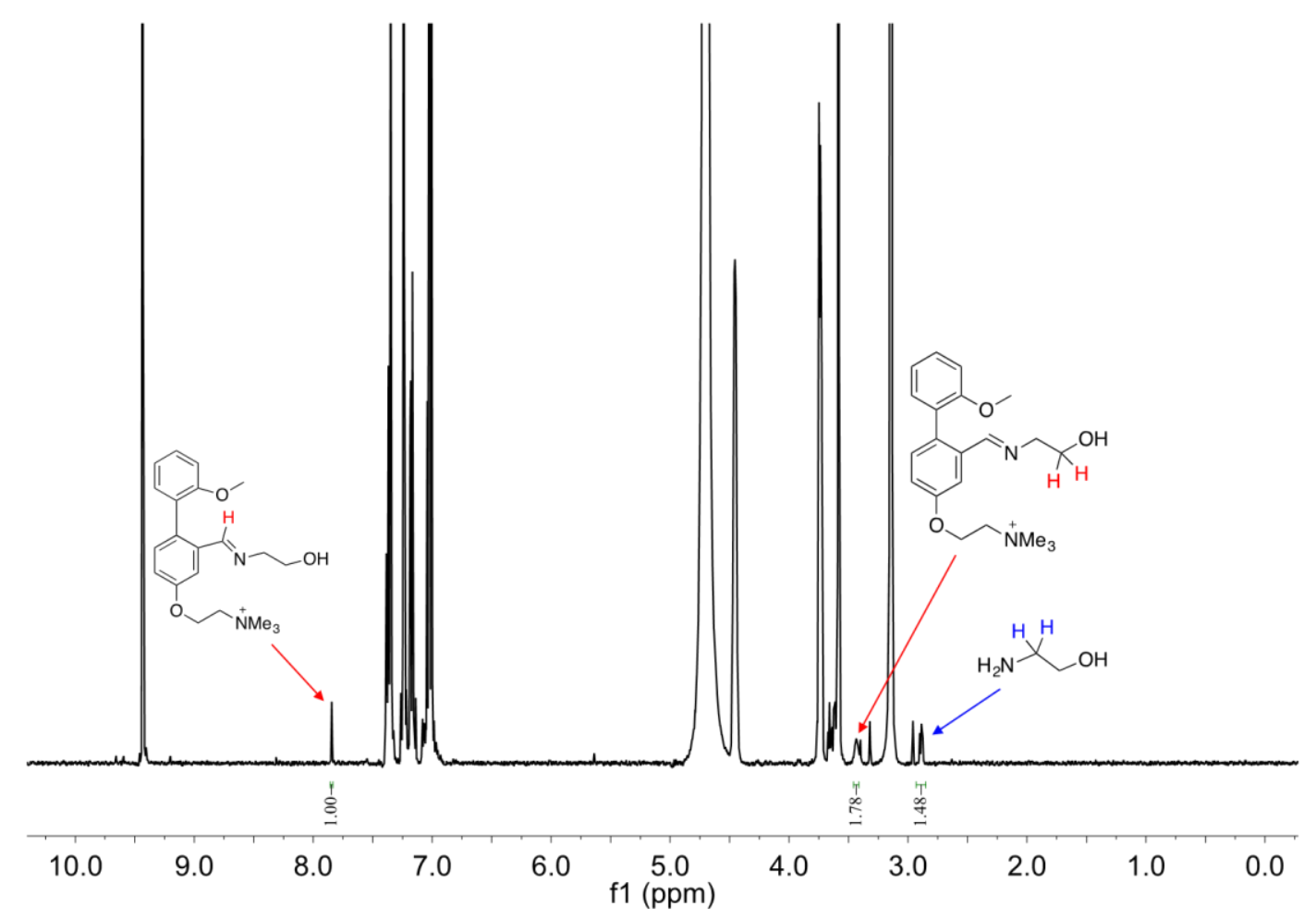

Figure S88. ${ }^{1} \mathrm{H}$ NMR spectrum of the reaction of $3(\mathrm{OMe})(20 \mathrm{mM}, 10.0$ equiv. $)$ and ethanolamine (2 mM, 1.0 equiv.) in $\mathrm{KPi}$ buffer solution in $\mathrm{D}_{2} \mathrm{O}(20 \mathrm{mM}, \mathrm{pH}=7.8)$. The yield of imine is $54 \%$. 


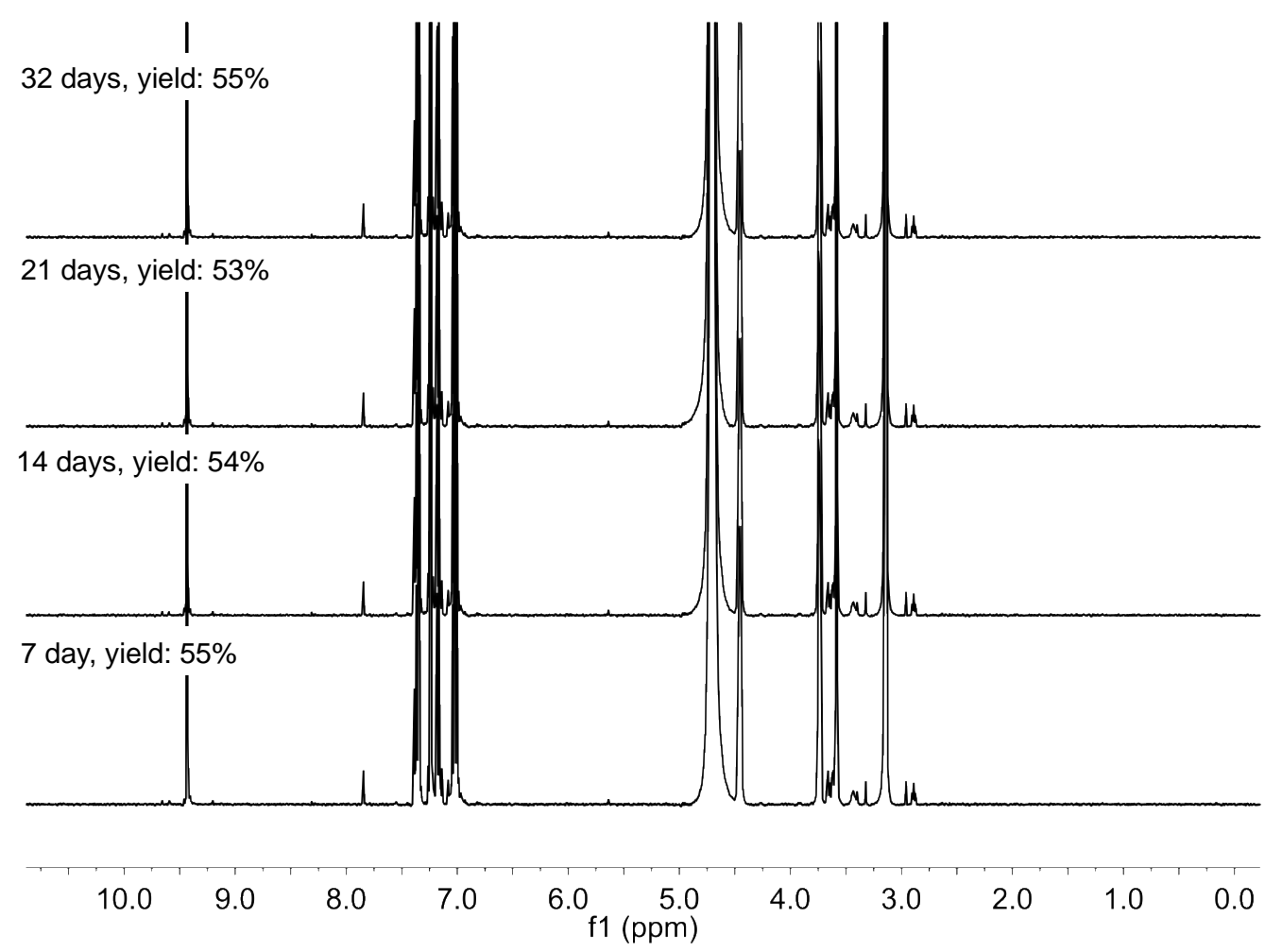

Figure S89. ${ }^{1} \mathrm{H}$ NMR spectra of the reaction of $\mathbf{3}(\mathrm{OMe})(20 \mathrm{mM}, 10.0$ equiv.) and ethanolamine ( $2 \mathrm{mM}, 1.0$ equiv.) in $\mathrm{KPi}$ buffer solution in $\mathrm{D}_{2} \mathrm{O}(20 \mathrm{mM}, \mathrm{pH}=7.8)$ at varied time. No decomposition of imine occurred.

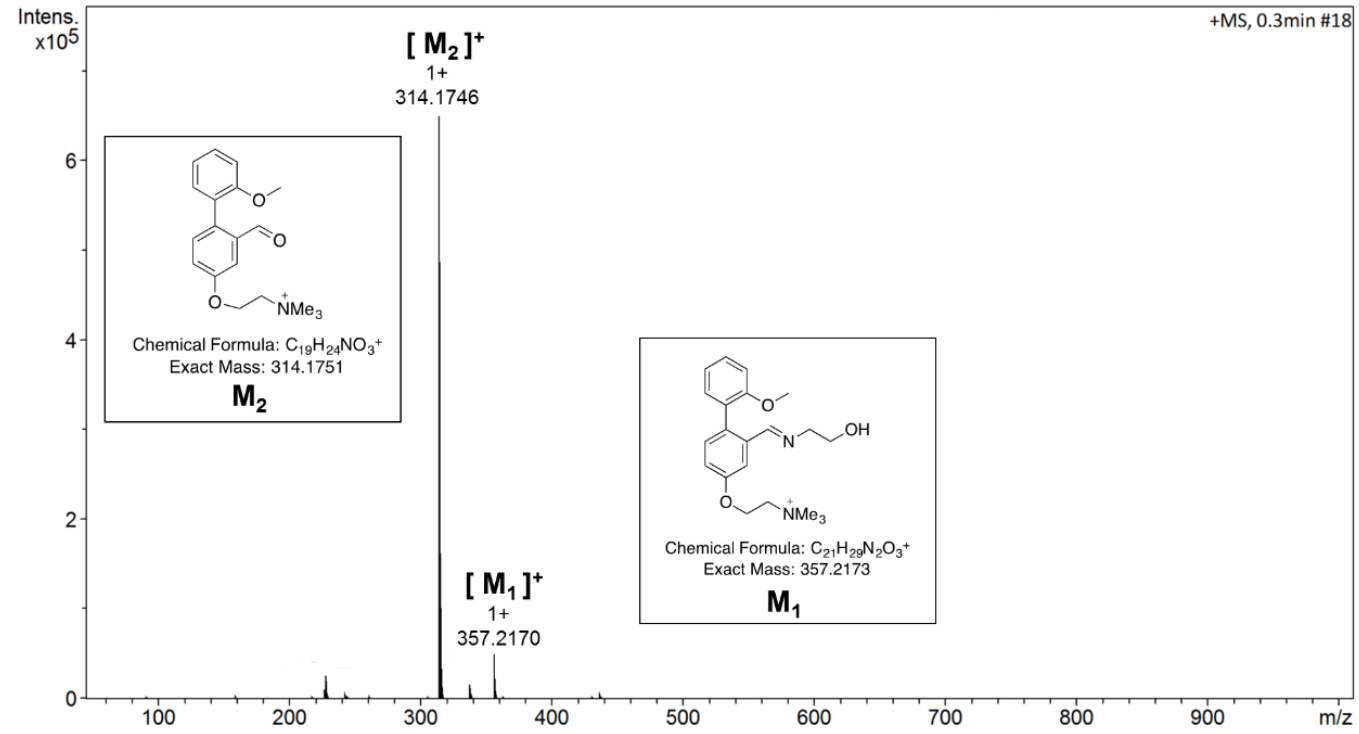

Figure S90. ESI-MS spectrum of the reaction of $\mathbf{3}(\mathrm{OMe})(20 \mathrm{mM}, 1.0$ equiv.) and ethanolamine (10 mM, 1.0 equiv.) in $\mathrm{KPi}$ buffer solution in $\mathrm{D}_{2} \mathrm{O}(20 \mathrm{mM}, \mathrm{pH}=7.8)$. 


\section{References}

S1. Fürstner, A.; Mamane, V. Flexible Synthesis of Phenanthrenes by a $\mathrm{PtCl}_{2}$-Catalyzed Cycloisomerization Reaction. J. Org. Chem. 2002, 67, 6264.

S2. Wallis, J. D.; O'Leary, J. Interactions and Reactions in Some 2,2'-Disubstituted Biphenyls-An Open or Shut Case. Org. Biomol. Chem. 2009, 7, 225.

S3. Sindelar, M.; Lutz, T. A.; Petrera, M.; Wanner, K. T. Focused Pseudostatic Hydrazone Libraries Screened by Mass Spectrometry Binding Assay: Optimizing Affinities toward $\gamma$-Aminobutyric Acid Transporter 1. J. Med. Chem. 2013, 56, 1323.

S4. Knowles, J. P.; O'Connor, V. E.; Whiting, A. Studies towards the Synthesis of the Northern Polyene of Viridenomycin and Synthesis of Z-Double Bond Analogues. Org. Biomol. Chem. 2011, 9, 1876.

S5. Fu, H.-Y.; Xu, N.; Pan, Y.-M.; Lu, X.-L.; Xia, M. Emission Behaviours of Novel V- and $\mathrm{X}$-Shaped Fluorophores in Response to $\mathrm{pH}$ and Force Stimuli. Phys. Chem. Chem. Phys. 2017, $19,11563$.

S6. Khanapure, S. P.; Garvey, D. S.; Young, D. V.; Ezawa, M.; Earl, R. AGaston, R. D.; Fang, X.; Murty, M.; Martino, A.; Shumway, M.; Trocha, M.; Marek, P.; Tam, S. W.; Janero, D. R.; Letts, L. G. Synthesis and Structure-Activity Relationship of Novel, Highly Potent Metharyl and Methcycloalkyl Cyclooxygenase-2 (COX-2) Selective Inhibitors. J. Med. Chem. 2003, 46, 5484 .

S7. Carreras, J.; Gopakumar, G.; Gu, L.; Gimeno, A.; Linowski, P.; Petuškova, J.; Thiel, W.; Alcarazo, M. Polycationic Ligands in Gold Catalysis: Synthesis and Applications of Extremely $\pi$-Acidic Catalysts. J. Am. Chem. Soc. 2013, 135, 18815.

S8. Tang, J.; Sivaguru, P.; Ning, Y.; Zanoni, G.; Bi, X. Silver-Catalyzed Tandem C $\equiv C$ Bond Hydroazidation/Radical Addition/Cyclization of Biphenyl Acetylene: One-Pot Synthesis of 6-Methyl Sulfonylated Phenanthridines. Org. Lett. 2017, 19, 4026.

S9. Sheng, L.; Kurihara, K. Generation of Catalytic Amphiphiles in a Self-Reproducing Giant Vesicle. Chem Lett. 2016, 45, 598.

S10. Frisch, M. J.; Trucks, G. W.; Schlegel, H. B.; Scuseria, G. E.; Robb, M. A.; Cheeseman, J. R.; Scalmani, G.; Barone, V.; Mennucci, B.; Petersson, G. A.; Nakatsuji, H.; Caricato, M.; Li, X.; Hratchian, H. P.; Izmaylov, A. F.; Bloino, J.; Zheng, G.; Sonnenberg, J. L.; Hada, M.; Ehara, M.; Toyota, K.; Fukuda, R.; Hasegawa, J.; Ishida, M.; Nakajima, T.; Honda, Y.; Kitao, O.; Nakai, H.; Vreven, T.; Montgomery, J. A., Jr.; Peralta, J. E.; Ogliaro, F.; Bearpark, M.; Heyd, J. J.; Brothers, E.; Kudin, K. N.; Staroverov, V. N.; Kobayashi, R.; Normand, J.; Raghavachari, K.; Rendell, A.; Burant, J. C.; Iyengar, S. S.; Tomasi, J.; Cossi, M.; Rega, N.; Millam, J. M.; Klene, M.; Knox, J. E.; Cross, J. B.; Bakken, V.; Adamo, C.; Jaramillo, J.; Gomperts, R.; Stratmann, R. E.; Yazyev, O.; Austin, A. J.; Cammi, R.; Pomelli, C.; Ochterski, J. W.; Martin, R. L.; Morokuma, K.; Zakrzewski, V. G.; Voth, G. A.; Salvador, P.; Dannenberg, J. J.; Dapprich, S.; Daniels, A. D.; Farkas, Ö.; Foresman, J. B.; Ortiz, J. V.; Cioslowski, J.; 
Fox, D. J. Gaussian 09, revision D.01; Gaussian, Inc.: Wallingford, CT, 2010.

S11. Glendening, E. D. Reed, A. E.; Carpenter, J. E.; Weinhold, F. NBO, version 3.1; Gaussian, Inc.: Wallingford, CT, 2010.

S12. Johnson, E. R.; Keinan, S.; Mori-Sánchez, P.; Contreras-García, J.; Cohen, A. J.; Yang, W. Revealing Noncovalent Interactions. J. Am. Chem. Soc. 2010, 132, 6498.

S13. Lu, T.; Chen, F. Multiwfn: A Multifunctional Wavefunction Analyzer. J. Comput. Chem. 2012, 33, 580 .

S14. Humphrey, W.; Dalke, A.; Schulten, K. VMD: Visual Molecular Dynamics. J. Mol. Graphics 1996, 14, 33.

S15. Reichardt, C.; Welton, T. Solvents and Solvent Effects in Organic Chemistry. WILEY-VCH Verlag GmbH \& Co. KGaA, Weinheim, 2011. 